\title{
Stable Isotopes Analysis of Caribou Antlers as Ecological Indicators
}

Matthew Brenning

A Thesis submitted to the Faculty of Graduate and Postdoctoral Affairs in partial fulfillment of the requirements for the degree of

\author{
Master of Science \\ In \\ Earth Science \\ Carleton University \\ Ottawa, Ontario
}

(C) 2020

Matthew Brenning 


\section{Abstract}

This study aims to determine whether Rangifer tarandus (caribou) antlers provide a unique isotopic signal relative to other hard tissues such as bone and teeth using stable isotopes of oxygen, carbon, and nitrogen. Variation in the rate and timing of tissue development should create different stable isotope profiles for each tissue. Tissue from fifteen male specimens housed at the Canadian Museum of Nature were sampled. Stable isotope analysis was conducted along the length of the antler, on the third molar, and the mandible. Isotopic differences were found between the three tissues, with the carbonate carbon $\left(\delta^{13} \mathrm{C}\right)$ and collagen nitrogen $\left(\delta^{15} \mathrm{~N}\right)$ isotopes showing significant patterns of variation along the length of the antlers. Isotopic variation along the antler length could potentially reflect ecological or physiological changes within the male caribou. Addition testing with plant samples, including mixing models with antler values, may provide deeper insight into this isotopic variation. 


\section{Acknowledgements}

Dr. Danielle Fraser is an outstanding supervisor, she has provided me with support both in the lab and on the page. I am so grateful that I have had such an encouraging mentor in my corner. I would not have been able to complete this project without her and I owe so much of this thesis to her.

I would also like to acknowledge my amazing committee who have been both teachers and critics helping me shape this project. My work has been greatly improved through the advice of Dr. Joyce Lundberg. Dr. Clément Bataille and Dr. Hillary Maddin were also fantastic teachers during my two years as a master's student, they both taught me a great deal about evolution and stable isotopes.

I would also like to thank Dr. Fred Longstaffe for processing the stable isotopes, without the work of him and his team there would literally be no thesis. He provided so much helpful feedback especially when the oxygen isotopes would not produce any results.

I thank my family and all my classmates who have helped me through this experience, going through the highs and lows of a massive project.

Lastly, I would like to acknowledge the Algonquin people as Carleton University is situated within the unceded traditional territory of the Algonquin people. 


\section{Table of Contents}

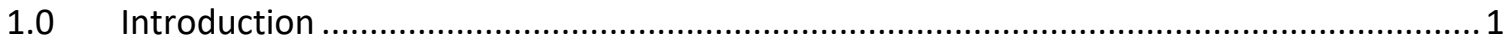

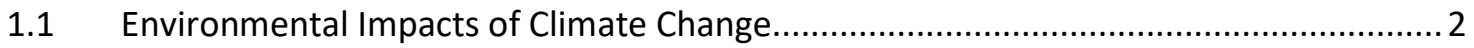

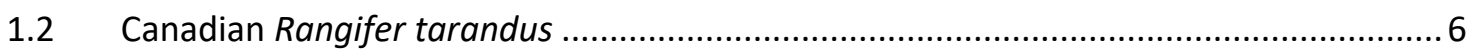

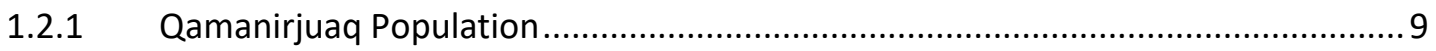

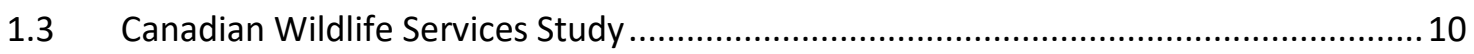

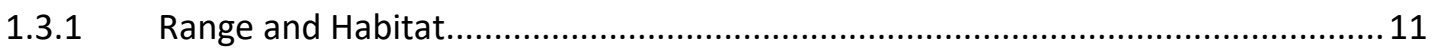

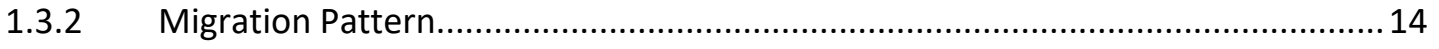

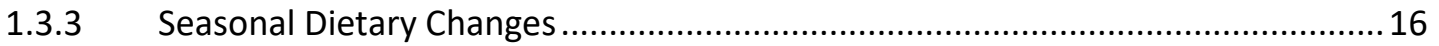

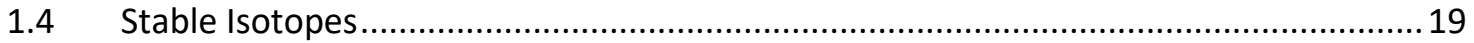

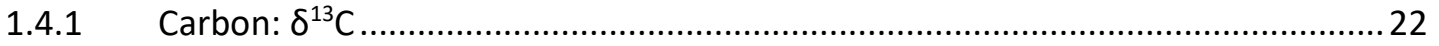

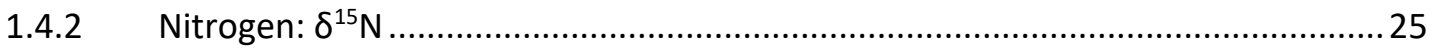

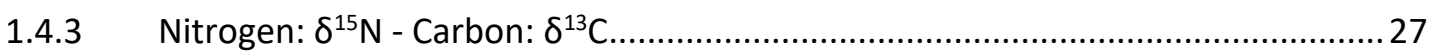

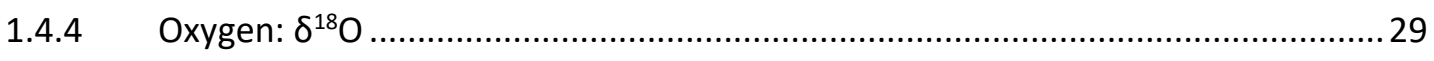

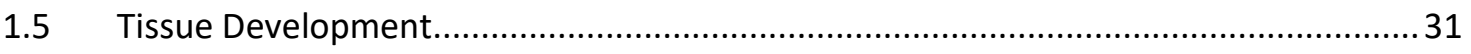

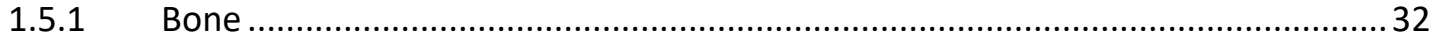

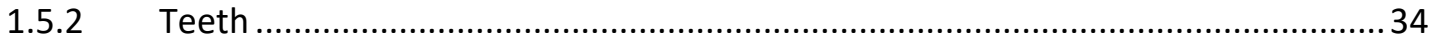

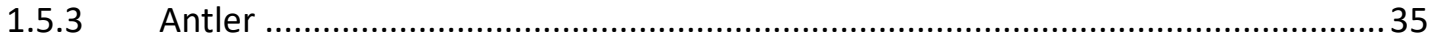

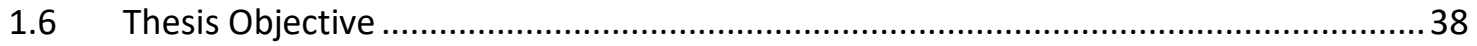

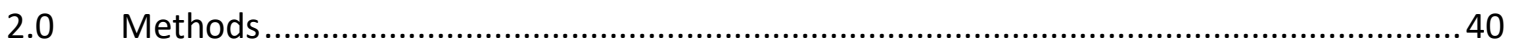

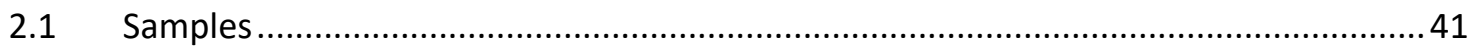

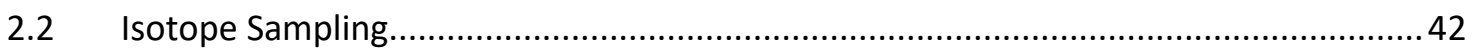

2.2.1 Carbonate chemical pre-preparation ............................................................... 43

2.2.2 Collagen chemical pre-preparation ................................................................ 44

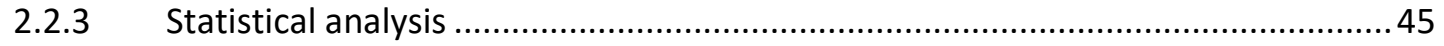

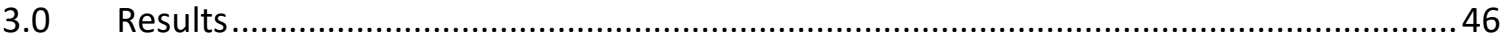

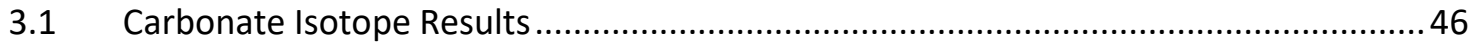

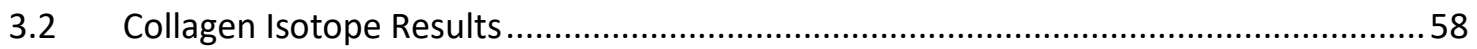

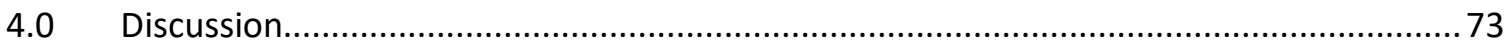

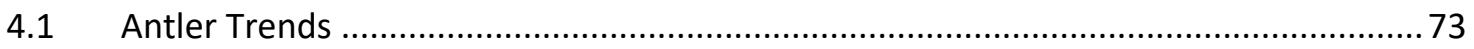

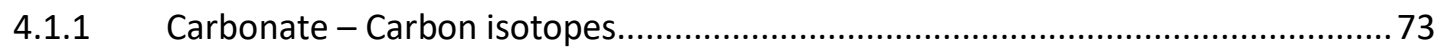

4.1.2 Carbonate - Oxygen isotopes ...................................................................... 76 


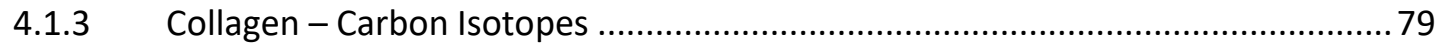

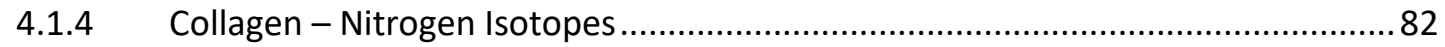

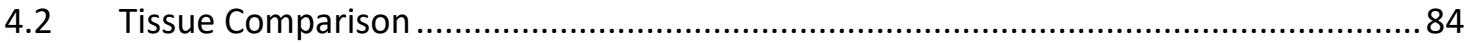

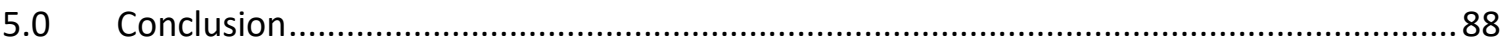

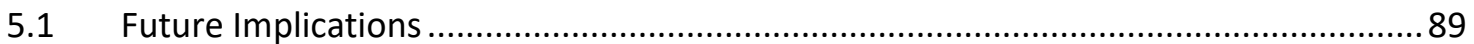

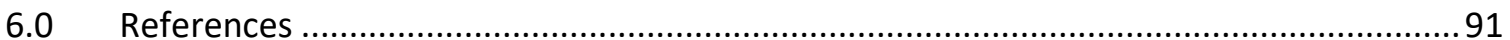




\section{List of Tables}

Table 1: Percentage of occurrence of plants in caribou rumen samples ...................... 16

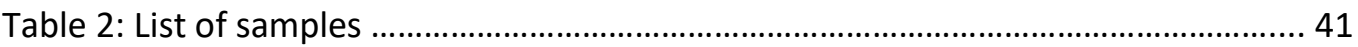

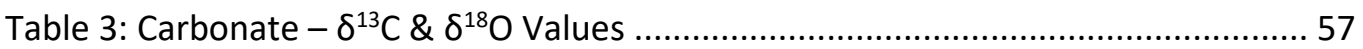

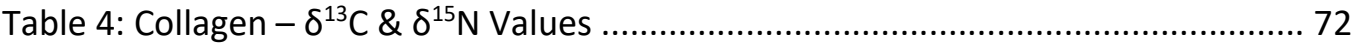

\section{List of Illustrations}

Figure 1: Barren-Ground Caribou populations within Canada .................................. 7

Figure 2: Ecozones and ecoregions within the Beverly and Qamanirjuaq caribou ...... 13

Figure 3: Spring migration pattern and Fall migration pattern ................................. 15

Figure 4: Major forage items found in caribou rumen samples ................................ 18

Figure 5: Distribution of $C_{3}$ and $C_{4}$ plants throughout the globe .............................. 23

Figure 6: Trophic level and base plant diet impact on stable isotopes ....................... 29

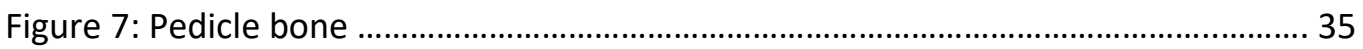

Figure 8: Tooth development and process …….............................................................. 37

Figure 9: Antler structure and nomenclature ……..................................................... 42

Figure 10: Carbonate - Antler Carbon $\delta^{13} \mathrm{C}$ Values ..................................................... 48

Figure 11: Carbonate - Antler Oxygen $\delta^{18} \mathrm{O}$ Values ................................................... 49

Figure 12: Carbonate Stable Isotope Repeatability Values ............................................. 52

Figure 13: Carbonate - Carbon $\delta^{13} \mathrm{C}$ Tissue Values .................................................... 53

Figure 14: Carbonate - Oxygen $\delta^{18} \mathrm{O}$ Tissue Values .................................................. 55

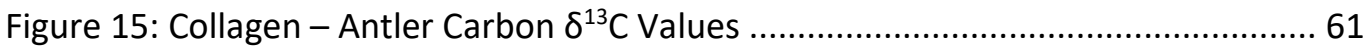

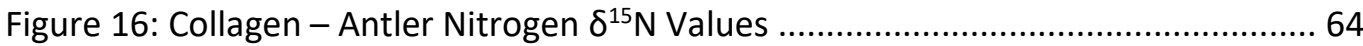

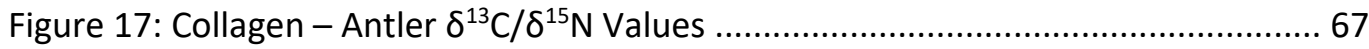

Figure 18: Antler Carbon $\delta^{13} \mathrm{C}$ Values: Carbonate/Collagen ........................................ 70

Figure 19: Review of the plant isotopes within the boreal forest and arctic tundra ...... 74

\section{List of Appendices}

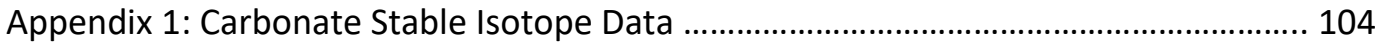

Appendix 2: Collagen Stable Isotope Data ………………................................................ 109 


\subsection{Introduction}

Rangifer tarandus (caribou) are of both ecologic and socio-economic importance to the North. They are a keystone species - a species that defines the structure of an ecosystem through regulation of fundamental ecosystem processes - of the polar food web, providing a food source for Arctic carnivores (e.g. wolves and bears) and many Indigenous societies (Wolfe, 2004; Barber et al. 2018; Latham et al. 2013; DeMars \& Boutin, 2017; Dickie et al. 2017; McLoughlin et al. 2003). Caribou in the North play an important ecological role, as they help to maintain the Arctic ecosystem through plantherbivore interactions (Mallory \& Boyce, 2018; Van der Wal, 2006) and distribute nutrients over long distances (Post et al. 2009; Van der Wal et al. 2007). For some indigenous groups, caribou represent an important economic resource and are of cultural significance (Wolfe, 2004; Mallory \& Boyce, 2018; Uboni et al. 2016). However, climate change in the Arctic region has resulted in the decline of many of Canada's major caribou populations (Mallory \& Boyce, 2018; Vors \& Boyce, 2009; Albon et al. 2017; Fauchald et al. 2017) and it is unclear the degree to which their ecology has changed during these decades of accelerated anthropogenic climate change (i.e. since the 1950 's). Studying caribou ecology through time requires analysis of both modern and Pleistocene caribou. Antlers would provide a non-lethal approach to field work study of modern caribou and make use of existing museum collections of Pleistocene caribou. Using stable isotope analysis, this study aims to determine whether antlers (as compared to other hard tissue of Rangifer tarandus) provide a unique and informative 
isotopic signature with the long term goal of determining whether caribou antler isotopes can help us better understand the ecology of caribou in Canada.

\subsection{Environmental Impacts of Climate Change}

Ongoing climate change is having profound global impacts, affecting animals, plants, and people. Scientists are making a global effort to better understand climate change and its implications, from studies on industrial development and human utilization (i.e. land use) to ecological state shifts and animal welfare (Parmesan, 2006; Dirzo et al. 2015). Our understanding of climate change and its ecological impacts is still evolving. An increase in global temperatures is driving global shifts in weather systems, vegetation dynamics, and the loss of animal habitat (Barnosky et al. 2012; Ceballos et al. 2015; Parmesan, 2006). Currently an estimated one million species are threatened with extinction due to climate change and anthropogenic impacts (IPBES, 2020). However, no region is experiencing larger perturbations in climate and ecology than the poles. Both the Arctic and Antarctic now have longer summers, shorter winters, and are experiencing increased ice and snow melting and precipitation (Post et al. 2009;

Trenberth et al. 2007). The poles have not experienced a comparable degree of warming for thousands to millions of years. In the Canadian Arctic, for example, the temperature has increased roughly $0.8-1.2^{\circ} \mathrm{C}$ over the past 150 years, the highest is has been for the last two million years (Trenberth et al. 2007; Ballantye et al. 2006; Post et al. 2009).

Temperature increases are amplified at the poles more than anywhere else on Earth due to the system of feedbacks between sea ice and snow extent, and solar 
energy (Graversen \& Wang, 2009). Albedo is a measure for solar energy reflected off the surface of the Earth. Ordinarily, the poles have a high albedo, as white snow and sea ice reflect solar rays away from the surface. However, climate change has critically altered this system. As temperatures rise, snow and sea ice extent have decreased significantly, causing a decrease in the overall albedo in the Polar Regions, allowing solar energy to reach the surface and further promoting snow and sea ice melt (Hall, 2004). Due to the decreased albedo amplifying the effects of climate change, the polar ecosystems have warmed at over twice the rate of the global average (NSIDC, 2020). The pronounced climate change experienced in the Arctic has resulted in alterations of vegetation dynamics and ecological landscape, with many species now endangered - such as the beluga whale, barren-ground caribou, eskimo curlew, and ivory gull (COSEWIC, 2019).

Polar Regions have comparatively low species diversity (i.e. are depauperate) and polar species are highly specialized, having adapted to their low productivity, highly seasonal environments (Anisimov et al. 2007; Mendoza \& Araújo, 2019). Such highly specialized species may fail to adapt to the amplified rate of the ecological change at the poles, leading to their extinction (Anisimov et al. 2007; Matveyeva \& Chernov, 2000). Due to the limited biocapacity of polar food webs, the decrease or possible extinction of one species may have substantial impacts on the remaining biota. The loss of keystone species (e.g. caribou, lemmings), in particular, can have cascading effects that deeply impact the remaining species. In Greenland, collared lemmings - a keystone species in the tundra ecosystem - are on the decline due to climate change (Schmidt et al. 2012; Gilg et al. 2012; Ims \& Fuglei, 2005). The collapse of this lemming population has led to 
the reduction of high-arctic predators like the snowy owl and stoat (Schmidt et al. 2012;

Gilg et al. 2009; Ims \& Steen, 1990). Thus, of all the global species, polar species are particularly vulnerable to climate change (Anisimov et al. 2007).

Warmer temperatures have also allowed the invasion of new species into polar environments. In areas like the Arctic, extended warm growing periods have allowed the encroachment of southern plant species (Post et al. 2009; Jepsen et al. 2008;

Christensen et al. 2007). In some cases, the specialized polar species struggle to compete with the invading species (Kutz et al. 2009; Polley \& Thompson, 2009;

Davidson et al. 2011). As southern shrub and tree populations expand northward, they alter the Arctic soil through increased microbial activity, higher winter soil temperatures, and increased nutrient mineralization rates (Post et al. 2009; Sturm, 2005). Soil alteration has created a positive feedback loop, promoting the further growth of southern shrubs and trees at the expense of native plant populations (Strum, 2005; Post et al. 2009). As southern shrub and tree populations expand northward, they also bring foreign parasites and pests that can cause significant disruption to native plant communities (Callaghan \& Johansson, 2009; Post et al. 2009). This "shrubification" of the Arctic is also having bottom up effects that impact Arctic megafauna like caribou and musk oxen, as the southern plants provide comparatively poor nutrient sources (Mallory \& Boyce, 2018; Thompson \& Barboza 2014; Post et al. 2009). Alteration of the plant growth season in the Arctic has created a trophic mismatch, leading to peak demand for resources by reproductive megafauna females falling later than seasonal 
peak resource availability. This has contributed to a reduction in survival of offspring (Post et al. 2009; Post \& Forchhammer, 2008).

The impact of climate change on megafauna is particularly important within the Arctic ecosystem as Arctic megafauna (e.g. megaherbivores) are essential to the maintenance of Arctic ecosystems because they are ecological engineers (Macias-Fauria et al. 2020). Species like caribou, muskoxen, bison, and Yakutian horse are important for maintaining the Arctic tundra ecosystem. Arctic megaherbivores reduce the shrubification of the tundra ecosystem through grazing, trampling and nutrient recycling - i.e. fecal deposition (Post et al. 2009; Van der Wal et al. 2007). The tundra ecosystem has more reflective surfaces than ecosystems dominated by shrub or forest. Forest and shrub ecosystems have limited exposed snow cover, which creates a smaller reflective surface than the tundra ecosystem. Megaherbivores within the Arctic help increase exposed snow cover by reducing the shrubification of the tundra and negating some of the loss of albedo (Zimov et al. 2012). Migration of the Arctic megaherbivores also causes the trampling of snow cover, which leads to colder, deeper freezing in the winter soil - increasing natural permafrost (Macias-Fauria et al. 2020; Zimov et al. 2012). Arctic megaherbivores are a natural solution to mitigate the rapid Arctic warming (MaciasFauria et al. 2020; Griscom et al. 2017). Their loss would further increase the already rapid warming of the Arctic (Mallory \& Boyce, 2018; Macias-Fauria et al. 2020). MaciasFauria et al. (2020) proposed a climate change mitigation plan involving the reintroduction or expansion of bison, Yakutian horse, and caribou populations to Arctic ecosystems. 
For plans like those proposed by Macias-Fauria et al. (2020) to be viable, we need to understand how Arctic species have and will likely respond to climate change. However, this requires access to appropriate, widely available, and informative ecological baseline data that can be used to compare the historical and paleontological ecology of Arctic megaherbivores and their modern counterparts. In this regard, the long term goal of my research is to use stable isotopes from antlers to understand how the ecology of caribou has or has not changed over long (thousands of years) and short (tens of years) timescales.

\subsection{Canadian Rangifer tarandus}

Caribou are found across the northern half of Canada. The majority of Canadian caribou are classified as a migratory species that are divided into three distinct subspecies. The division of subspecies is based on overall body size, antler shape, fur colour, and habitat. They include the Boreal Woodland Caribou, the Mountain Caribou, and the BarrenGround Caribou. The Barren-Ground Caribou (Rangifer tarandus groenlandicus) is the smallest of the three distinct subspecies, distinguishable by their large curvy antlers, lighter pelage, and common habitat range of the Northwest Territories and Nunavut (COSEWIC, 2019). The Barren-Ground Caribou are the subject of my thesis, selected for their northern population distributions throughout Canada (Fig. 1) (Parlee et al. 2018). 


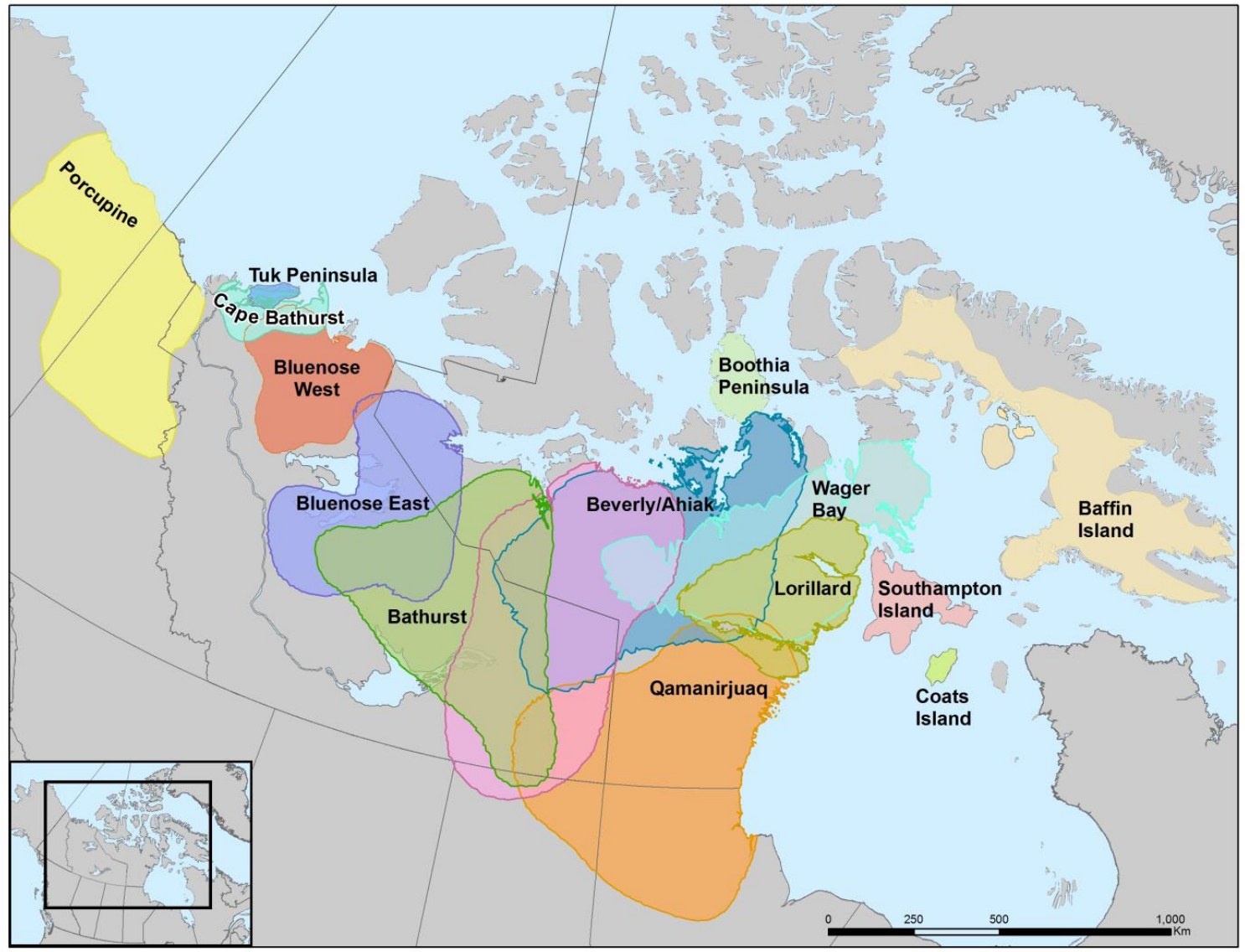

Figure 1. Barren-Ground Caribou populations within Canada (stars mark sampling location from Canadian Wildlife Services study in 1966-68) (COSEWIC, 2011; Parlee et al. 2018).

The Barren-Ground Caribou populations in Canada fluctuate in size on a decadal scale, with the most recent peak being in the late 1980s and early 1990s (BQCMB, 2020; Evans, 2019). However, they have since been on a steady decline, with some populations experiencing more drastic declines than others (Mallory \& Boyce, 2018; Post et al. 2009). While the significance of the decline varies, Canadian science groups have been working to better understand Barren-Ground Caribou population dynamics. They have shown that changing Arctic climate and ecology has, overall, had negative consequences for Barren-Ground Caribou populations. Several Canadian populations of 
this subspecies are expected to decrease by as much as $50 \%$ in the next $8-15$ years (Barber et al. 2018). In addition, many are now classified as populations of special concern, threatened, or endangered by the Committee on the Status of Endangered Wildlife in Canada (COSEWIC, 2014).

Many environmental factors caused by climate change are impacting the Barren-Ground Caribou populations of Canada. Increased periods of warming have resulted in longer summers allowing a longer grazing period, but it has also resulted in changing plant communities which has negative nutritional consequences (Mallory \& Boyce, 2018; Thompson \& Barboza, 2014). The plant communities are becoming more abundant in woody plants, which have a greater chemical and structural defense against herbivory, in addition to low quantities of protein (Thompson \& Barboza, 2014). Warmer periods also increase the number of parasitic flies, which can result in decreased body condition and reproduction of the Barren-Ground Caribou (Mallory \& Boyce, 2018; Thomas \& Kiliaan, 1990; Albon et al. 2002; Hughes et al. 2009; Ballesteros et al. 2012; Cuyler et al. 2012; Pachkowski et al. 2013). Finally, warming is associated with an increase in icing events during the winter and an increase in wildfires during the summer. Both can cause catastrophic starvation periods for Barren-Ground Caribou populations, greatly altering their mortality as well as winter and summer ranges (Mallory \& Boyce, 2018; Tyler, 2010; Joly et al. 2012; Anderson \& Johnson, 2014). 


\subsubsection{Qamanirjuaq Population}

The largest population of Barren-Ground Caribou is the Qamanirjuaq population, identified in Figure 1 in orange (COSEWIC, 2014; BQCMB, 2020). The herd is located primarily in Nunavut but has a migratory range that expands west into the Northwest Territories and south into northern Saskatchewan and Manitoba. The Qamanirjuaq herd, along with another population, the Beverly herd, have been harvest by the Inuit, Dene, Cree, and Métis indigenous groups for decades (Evans, 2019). In 1982, the Beverly and Qamanirjuaq Caribou Management Board (BQCMB) was established to safeguard the Qamanirjuaq and Beverly herds of Barren-Ground Caribou. Among other activities, BQCMB has studied the population dynamics of these two populations. In 1994, BQCMB estimated the Qamanirjuaq caribou population at 496,000. However, the herd has been on a steady decline (about $2 \%$ per year) and as of 2017 its population was estimated at 288,000 . BQCMB has rated the Qamanirjuaq population as being of a medium to high vulnerability of decline and has advised that if the population continues to decline it may pass the point of recovery (BQCMB, 2020).

Given its size and socio-economic importance, the Qamanirjuaq population has been the subject of numerous scientific studies over the years (Parker, 1973; Miller F.L., 1973; Dauphine, 1973; Miller D.R., 1973; Drucker et al. 2010; 2012). These studies, along with the work of $\mathrm{BQCMB}$, are the reason I have chosen the Qamanirjuaq population for my research as the previous work has provided the ecological information necessary to contextualize the stable isotope analyses performed as part of my thesis. 


\subsection{Canadian Wildlife Services Study}

A Canadian Wildlife Services (CWS) study was conducted between 1966 and 1968 with a focus on creating a better understanding of caribou population dynamics, human utilization, and range conditions of the Qamanirjuaq and Beverly populations. The project was developed in response to conservation concerns related to the decreasing number of caribou during the 1940s. During the study, 999 Caribou were culled, 943 were from the Qamanirjuaq population and 56 from the Beverly population.

The CWS study was divided into four areas of review, each with its own set of goals (Parker, 1973; Miller, F.L. 1973; Dauphine, 1973; Millar, D. R. 1973). The areas of study included:

1. Total numbers, mortality, recruitment, and seasonal distribution

2. Sex and age composition

3. Seasonal physical and reproductive condition

4. Range evaluation

My thesis was conducted using caribou tissue gathered during the CWS study. Information on the range and habitat (including migration patterns) and the dietary preferences of the Qamanirjuaq population gathered during the study is summarized below. This information is relevant to the stable isotope analysis that was conducted as part of my thesis on the caribou tissue. 


\subsubsection{Range and Habitat}

The range of the Qamanirjuaq population is limited by climatic conditions during both the summer and winter. The population's range is approximately $282,310 \mathrm{~km}^{2}$, incorporating portions of two provinces, Manitoba $\left(102,020 \mathrm{~km}^{2}\right)$ and Saskatchewan $\left(16,680 \mathrm{~km}^{2}\right)$, and the districts of Mackenzie $\left(12,690 \mathrm{~km}^{2}\right)$ and Keewatin $\left(147,890 \mathrm{~km}^{2}\right)$ within Nunavut. The herd ranges above the tree line during the summer season in the tundra ecosystem, then retreats below it during the winter months to the boreal forest ecosystem - see Figure 2 (Parker, 1973).

The range of the Qamanirjuaq population includes several ecozones: true tundra, a transition zone and boreal forest. True tundra is characterized by frequent outcrops, glacial drifts, muskegs, and low flat Carex (Sedge) meadows. South of the true tundra environment is a forest-tundra transition zone marked by intermixed vegetation of Carex meadows and a few stunted trees (i.e. black spruce, willow, birch, and tamarack). South of the tree line is reached the area is dominated by boreal forest, which is primarily black and white spruce, with the infrequent growth of other trees such as white birch, tamarack, jack pine, stunted aspen, and balsam poplar (Larsen, 1965; Parker 1973). The temperatures of the true tundra range with mean monthly temperatures of $-25.5^{\circ} \mathrm{C}$ to $9^{\circ} \mathrm{C}$, while the temperature range in the southern part of the Qamanirjuaq distribution (i.e. in northern Manitoba and Saskatchewan) is warmer with mean monthly temperatures of $15^{\circ} \mathrm{C}$ and minimum temperatures of $-20^{\circ} \mathrm{C}$ (Parker, 1973; Kendrew \& Currie, 1955). The entire range of the Qamanirjuaq population 
experiences a mean annual snowfall of roughly 120 to $150 \mathrm{~cm}$, while total annual precipitation rarely exceeds $400 \mathrm{~mm}$ (Parker, 1973). 


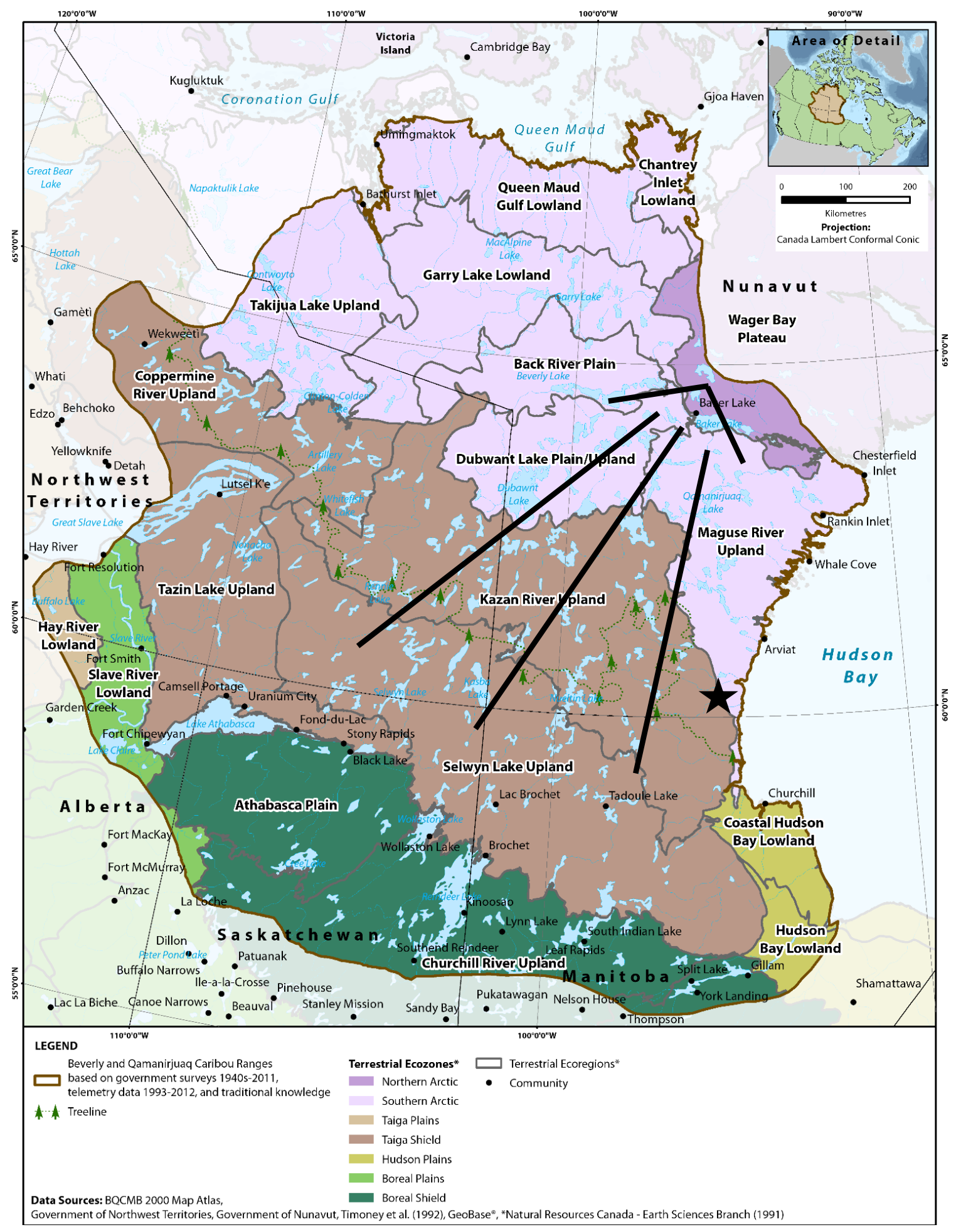

Figure 2. Ecozones and ecoregions within the Beverly and Qamanirjuaq caribou ranges taken from the Government of Northwest Territories, Government of Nunavut, Timoney et al. (1992), arrows showing spring migratory pattern. Star indicates sample collection site. 


\subsubsection{Migration Pattern}

The migration pattern of the Qamanirjuaq population is largely unchanged since the CWS study (as illustrated in Fig. 3). The majority of the herd, excluding adult males, winter in northern Saskatchewan and Manitoba. Adult males tend to scatter throughout the forest region during the winter as either individuals or small bands. Spring migration begins in April, with cows, calves, and yearlings moving north/northeast (Fig. 3). The herd moves in bands that vary in size from a few individuals to thousands. While cows, calves, and yearlings move north, the majority of males older than 23 months do not leave the tree line until June. Throughout June and July, adult males remain scattered and only begin migrating north towards the end of July. After August, caribou retreat southward and congregate into three main groups: the Churchill, Duck Lake, and Windy Bay herds (Fig. 3). By late September, the groups begin to merge in the west near North Henik Lake in preparation for the rut (Fig. 3). After the rut (i.e. mating season) in early November, the fall migration occurs as the caribou head towards the tree line. Throughout this migration the CWS study observed that caribou of the Qamanirjuaq population travel roughly 13 miles per day (Parker, 1973). 

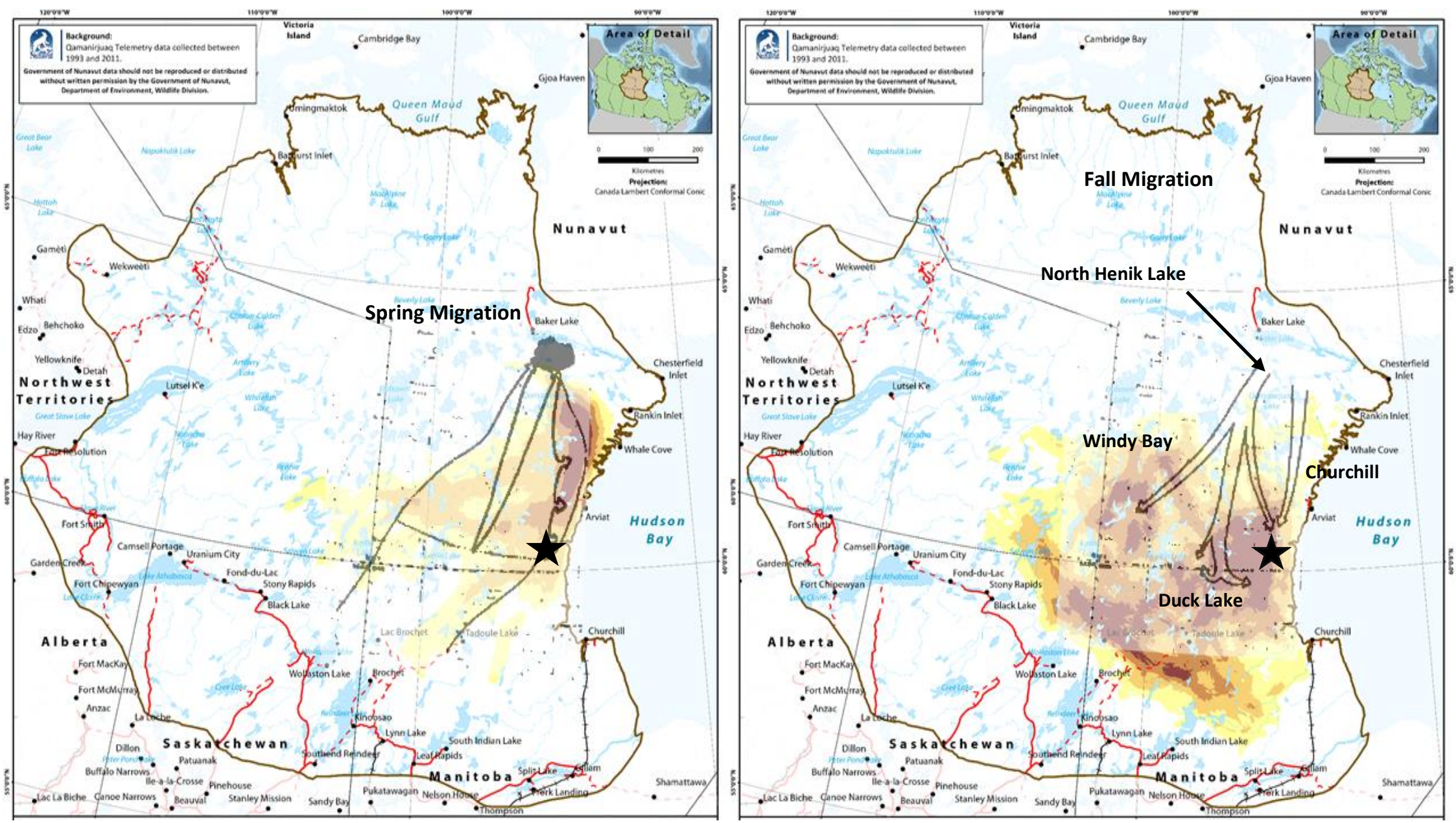

Figure 3. Spring migration pattern (left) and Fall migration pattern (right) for Qamanirjuaq caribou population. The colouration indicates the intensity of land use by the Qamanirjuaq population throughout the spring migration collected between 1996-2012 by the Government of Northwest Territories, Government of Nunavut, and Natural Resources Canada. Overlaid are migratory patterns identified in the CWS study for 1967 from images made by F.L. Miller in 1973 (BQCMB, 2020; Miller F.L., 1973). Star indicates the sample collection site. 


\subsubsection{Seasonal Dietary Changes}

Seasonal dietary changes were examined as part of the CWS study. Rumen samples (i.e. stomach content) were collected throughout the 1966 to 1968 collection period. The analysis found significant differences in seasonal diets (Fig. 4). In the winter season, caribou consumed more lichen than any other plant species (Table 1), aligning with the known migration patterns (Fig. 3). The winter diet in the boreal forest was primarily made up of terrestrial lichens, Cladina spp. and Cladonia spp. Stereocaulon, an important food source prior to snow melt (Miller F.L., 1973).

Table 1. Percentage of occurrence of plants in caribou rumen samples. Numbers in bold indicate the number of rumens sampled. The columns are broken into the various collection periods conducted during the Canadian Wildlife Services study (Miller F.L. 1973).

\begin{tabular}{|c|c|c|c|c|c|c|}
\hline \multirow[b]{3}{*}{ Plants } & \multicolumn{6}{|c|}{ Collection Period } \\
\hline & \multirow{2}{*}{$\begin{array}{l}\text { Jan.- } \\
\text { Feb. } \\
\qquad 1967\end{array}$} & \multicolumn{3}{|c|}{ April } & \multicolumn{2}{|c|}{ November } \\
\hline & & 1966 & 1967 & 1968 & 1966 & 1967 \\
\hline Bryophyta & 14 & 19 & 20 & 20 & 20 & 20 \\
\hline Polytrichium commune & 43 & 21 & 40 & 10 & 45 & 25 \\
\hline P. junipernum & 50 & 16 & 85 & 70 & 70 & 35 \\
\hline P. piliferum & 36 & 0 & 66 & 50 & 55 & 20 \\
\hline Dicranum spp. & 50 & 63 & 95 & 15 & 20 & 35 \\
\hline $\begin{array}{r}\text { Drepanocladus } \\
\text { uncinatus }\end{array}$ & 14 & 0 & 25 & 5 & 0 & 5 \\
\hline Pleurozium schreberi & 57 & 58 & 85 & 68 & 20 & 20 \\
\hline Hylocomium splendens & 0 & 0 & 15 & 0 & 0 & 0 \\
\hline Ptilidium ciliare & 64 & 84 & 100 & 75 & 25 & 50 \\
\hline Lichens & 7 & 26 & 80 & 72 & 85 & 57 \\
\hline Cladina spp. & 100 & 96 & 90 & 100 & 100 & 100 \\
\hline Cladonia spp. & 43 & 65 & 20 & 54 & 62 & 42 \\
\hline Stereocaulon spp. & 86 & 62 & 96 & 19 & 35 & 53 \\
\hline Cetraria spp. & 0 & 0 & 0 & 0 & 4 & 0 \\
\hline Podetial & 100 & 89 & 97 & 100 & 100 & 100 \\
\hline 5\% Podetial & 86 & 75 & 82 & 54 & 28 & 30 \\
\hline Conifer Needles & 11 & 10 & 17 & 16 & 23 & 33 \\
\hline
\end{tabular}




\begin{tabular}{|r|r|r|r|r|r|r|}
\hline Larix laricina & 73 & 50 & 24 & 31 & 87 & 52 \\
\hline Picea spp. & 100 & 100 & 100 & 100 & 78 & 100 \\
\hline Pinus banksiana & 55 & 80 & 18 & 25 & 9 & 100 \\
\hline Woody Angiosperms & 12 & 16 & 16 & 16 & 15 & 16 \\
\hline Salix spp. & 0 & 0 & 0 & 0 & 0 & 0 \\
\hline Betula spp. & 17 & 19 & 63 & 50 & 13 & 38 \\
\hline Rubus chamaemorus & 8 & 0 & 0 & 19 & 0 & 0 \\
\hline Empetrum nigrum & 0 & 0 & 6 & 0 & 0 & 6 \\
\hline Ledum spp. & 67 & 75 & 94 & 94 & 100 & 81 \\
\hline Loiseleuria procumbans & 0 & 6 & 0 & 0 & 0 & 0 \\
\hline Kalmia polifolia & 42 & 31 & 19 & 31 & 47 & 50 \\
\hline Andromeda polifolia & 25 & 6 & 19 & 44 & 80 & 50 \\
\hline Chamaedaphne & 0 & 6 & 0 & 50 & 40 & 6 \\
\hline calyculata & & & & & & 0 \\
\hline Arctostaphylos rubra & 0 & 6 & 0 & 0 & 0 & 81 \\
\hline Vaccinium uliginosum & 92 & 81 & 75 & 19 & 67 & 89 \\
\hline V. myrtilloides & 92 & 94 & 38 & 44 & 100 & 80 \\
\hline vitis-idaea & 100 & 100 & 100 & 100 & 100 & 100 \\
\hline Grasslike Plants & 0 & 0 & 6 & 0 & 20 & 0 \\
\hline Equisetum spp. & 60 & 20 & 13 & 0 & 100 & 89 \\
\hline
\end{tabular}




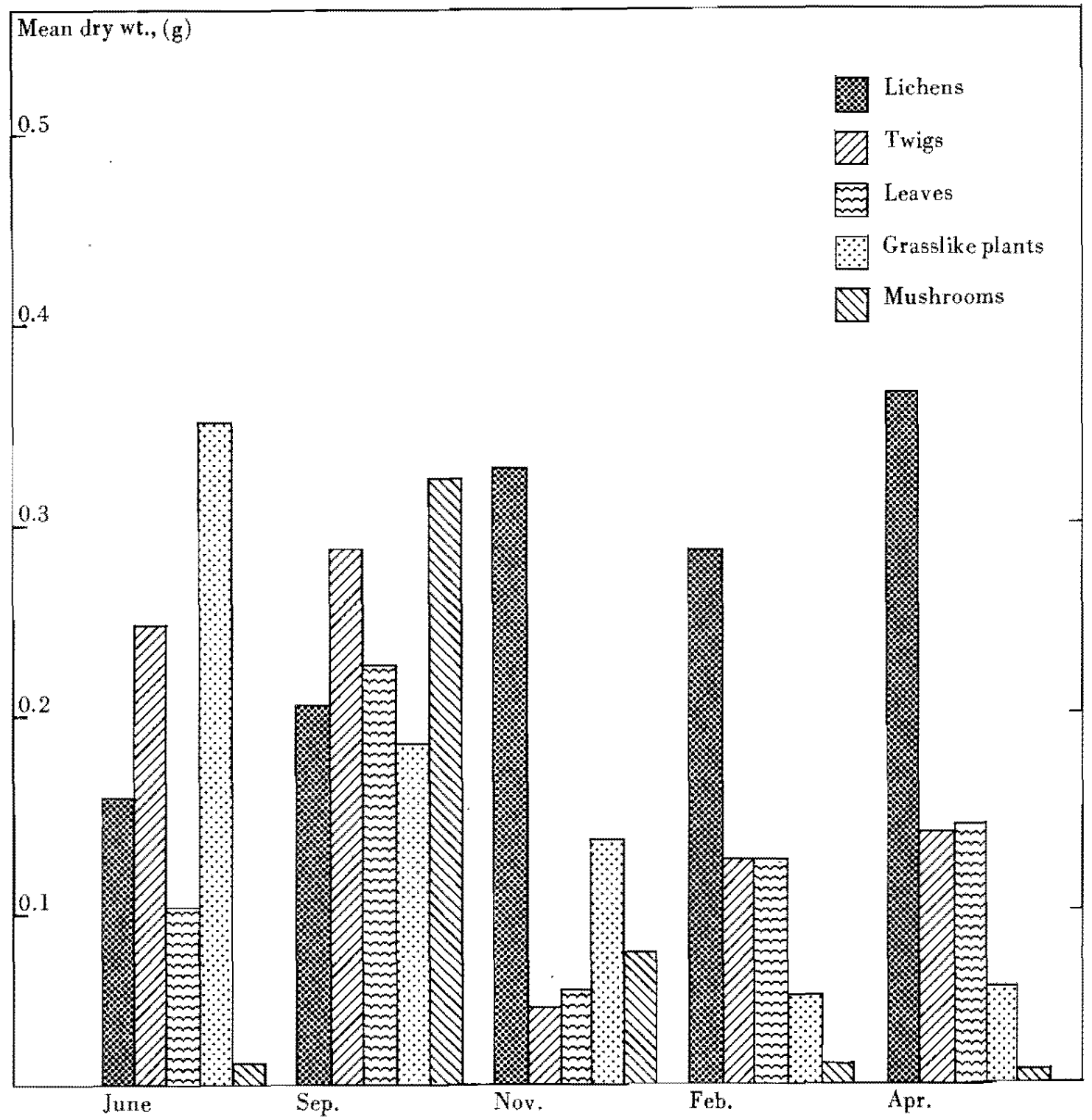

Figure 4. Weight of five major forage items found in caribou rumen samples collected between 1966-1968, months represented on the graph are additive from the three-year collection period (Miller D.R. 1973). 


\subsection{Stable Isotopes}

Stable isotopes analysis represents an integral part of my research, stable isotopes can provide information on the ecology of Rangifer tarandus. My long-term goal is to determine if isotopes within caribou antlers can be used to provide that ecological information. The first step toward this goal is determining if and to what degree stable isotopes vary along the antler and vary in pattern among bone, tooth, and antler. The term 'isotope' refers to an element that has two or more forms that differ in number of neutrons in their nuclei (Hoefs, 2009). Variation in the number of neutrons changes an element's atomic mass. The variants are commonly referred to as 'heavy' or 'light', depending on whether they possess greater or fewer neutrons. Atomic mass differences create variation between the rate at which an isotope reacts creating fractionation between the isotopes. Differences in the number of neutrons can also result in isotopes that are either stable or radioactive, the latter meaning they decay over time (Fry, 2008). Stable isotopes, the focus of my thesis, are those that do not undergo radioactive decay.

Stable isotopes differ significantly in abundance within the natural environment. There is typically a 'common' isotope, which makes up usually $90-99 \%$ of the molecules of an element, and then one or more 'uncommon' isotopes, which in some isotopes can be no greater than $1 \%$ of the molecules. Within a natural system, whether as a result of abiotic or biotic factors, the ratios of these different isotopes can vary due to a process called fractionation (Koch, 2007). Fractionation results from biases in physical and chemical processes that occur due to variations in isotopic mass (i.e. of the 'heavy' and 
'light' isotopes) and differences in their bonds. These physical and chemical processes are typically biased against heavier stable isotopes. In highly kinetic environments (e.g. warm environments), for example, the fractionation between the heavy and light isotopes becomes less significant as energy becomes more readily available making it easier to process heavy isotopes (Fry, 2008). In contrast, low energy can cause the preferential reaction of lighter isotopes, creating a large fractionation between heavy and light isotopes (Farquhar et al. 1968). Variation in the abundance of stable isotopes is therefore measured as the fractionation difference, the difference between the heavy and light isotopes in the measured substance or tissue (Fry, 2008).

Stable isotope composition is expressed in $\delta$ notation. Here the ratio of heavy to light isotope from a sample are compared to an international set standard (standards are maintained by the International Atomic Energy Association). After the two ratios are compared, they are subtracted by one then multiplied by 1000 to create a stable isotope value that is in parts per thousand (Fry, 2008).

$$
\delta R^{\text {Heavy } / \text { Light }} \text { in } \% 0=\left\{\frac{R_{\text {Heavy } / \text { Light }}^{\text {Sample }}}{R_{\text {Heavy } / \text { Light }} \text { Standard }}-1\right\} \times 1000
$$

To determine the value of a sample stable isotope analysis is used to analyze precise isotopic abundances. From these values we can begin to attempt to understand where isotopic fractionation between the isotopes has occurred. The first discovery of stable isotopes was developed roughly 100 years ago when Francis W. Aston first saw three isotopes of neon (Fry, 2008). Since then, stable isotope analysis has become increasingly valuable to the Earth and Biological Sciences. High-sensitivity mass 
spectrometers have allowed a deeper understanding of stable isotope fractionation. Through the collaboration of research groups, we now have developed known global isotopic trends and a better understanding of the source of isotopic fractionation (Koch, 2007; Fry, 2008).

The application of stable isotope analysis in modern ecology has advanced greatly in the past 40 years. Scientific groups have found unique and revolutionary ways to use different stable isotopes. Global patterns and previous scientific studies have allowed more accurate predictions for the source of fractionation in modern ecology. Ecologists now use elements, such as hydrogen, oxygen, carbon, nitrogen, and sulfur to study unique components of biological and geological systems (Koch, 2007; Fry, 2008). Hydrogen and oxygen isotopes have been used to determine hydrological sources within an ecosystem, whether water is from rainfall or groundwater. Carbon and nitrogen isotopes are often used to determine dietary and trophic information about an organism. Sulfur, a component of many rocks, can be used to determine geographical changes or differences between terrestrial and marine food webs (Hobson \& Wassenaar, 1999; Ehleringer \& Rundel, 1989). These many studies have led to our modern understanding of stable isotope variation in ecological context and it is important we continue to work to expand this knowledge.

In completing my research, stable isotopes were examined in relation to three elements - carbon, nitrogen, and oxygen - in order to changes along the antler and differences in pattern among tissues. Below is a summary of the each of these isotopes and how they relate to terrestrial ecology. 


\subsubsection{Carbon: $\delta^{13} \mathrm{C}$}

Carbon has two naturally occurring stable isotopes: ${ }^{12} \mathrm{C}$, which makes up $98.9 \%$ of all stable carbon, and ${ }^{13} \mathrm{C}$ contributing to the remainder (Farquhar et al. 1968). Carbon fractionation - notated as $\delta^{13} \mathrm{C}$ - is the ratio between ${ }^{13} \mathrm{C} /{ }^{12} \mathrm{C}$ isotope abundances. The $\delta^{13} \mathrm{C}$ value can change among habitats, plant types, and within the atmosphere (Terri \& Stowe, 1976; Ehleringer et al. 1997). In the atmosphere, carbon is found primarily within atmospheric $\mathrm{CO}_{2}$. The $\delta^{13} \mathrm{C}$ of atmospheric $\mathrm{CO}_{2}$ can be affected by several different factors, including volcanism, melting permafrost, and the anthropogenic burning of fossil fuels (Hoefs, 2009; Freyer, 1979; Freyer \& Belacy, 1983; Trudinger et al. 1999, Heimann \& Maier-Reimer, 1996). However, variations in the isotopic composition of atmospheric carbon have only a slight influence on the $\delta^{13} \mathrm{C}$ values of ecosystems (. It is only a major concern when comparing different time periods (e.g. comparing thousands of years ago to today) (Long et al. 2005; lacumin et al. 1997; lacumin et al. 2000; Richards \& Hedges, 2003).

When considering terrestrial environments, atmospheric $\mathrm{CO}_{2}$ is incorporated into plant tissues through the stomata of leaves (Hoefs, 2009). Significant differences in $\delta^{13} \mathrm{C}$ do occur among terrestrial $\mathrm{C}_{3}$ plants and $\mathrm{C}_{4}$ plants, due to differences in $\mathrm{CO}_{2}$ uptake and resulting fractionation (Kelly, 2000; Sternberg, 1989; Ehleringer, 1991; Lajtha \& Marshall, 1994). Terrestrial $C_{3}$ plants (mean value of $\delta^{13} C=-27 \%$, range $=-35$ to $-21 \%$ ) use a primary $\mathrm{CO}_{2}$-fixing enzyme called RuBP (Ribulose 1,5 Bisphosphate) that will discriminate against the heavy isotope, ${ }^{13} \mathrm{C}$. In contrast, $\mathrm{C}_{4}$ plants (mean value of $\delta^{13} \mathrm{C}=-$ 
$13 \%$, range $=-14$ to $-10 \%$ o) have an additional step where PEP carboxylase acts as a pump, which directly transports $\mathrm{CO}_{2}$ to the $\mathrm{CO}_{2}$-fixing enzyme RuBP. The additional step reduces the discrimination against the heavier carbon isotope found in $\mathrm{C}_{3}$ plants (Kelly, 2000; O’Leary, 1981, 1988; Farquhar et al. 1989; Boutton, 1991; Ehleringer, 1991; Fry, 2008). As a result, $C_{3}$ and $C_{4}$ plants are isotopically differentiable.

Differences in the temperature and rainfall preferences for $C_{3}$ and $C_{4}$ plant species result in distributional differences and, thus, variation in $\delta^{13} \mathrm{C}$ values among different habitats. $C_{4}$ plants thrive in warm dry (xeric) climates (Ehleringer, 1991; Kelly, 2000) (Fig. 5). $C_{3}$ plants dominate mesic environments - an environment containing a moderate amount of moisture (Ehleringer, 1991; Kelly, 2000) (Fig. 5).

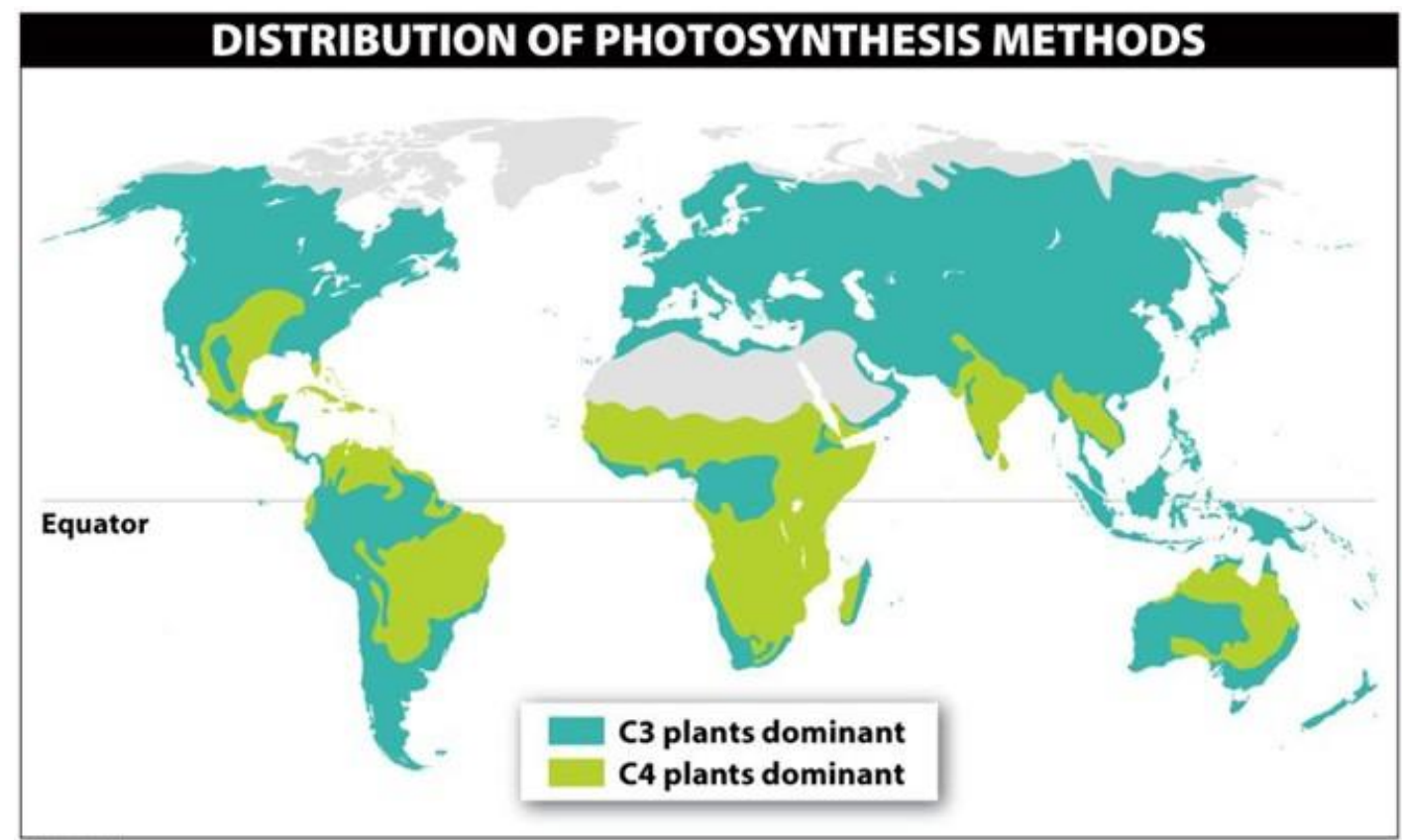

Figure 5. Distribution of $C_{3}$ and $C_{4}$ plants throughout the globe (Phelan, 2014).

$C_{3}$ and $C_{4}$ plants are unevenly distributed around the globe, $C_{3}$ plants are predominant at high-latitude whereas $\mathrm{C}_{4}$ plants are predominant at low-latitudes (Terri 
\& Stowe, 1976). The variation among $C_{3}$ and $C_{4}$ plant distribution is caused by temperature, moisture content, and atmospheric $\mathrm{CO}_{2}$ levels (Terri \& Stowe, 1976;

Ehleringer et al. 1997). For $C_{3}$ plants, photosynthesis becomes increasingly inefficient with high temperatures, low moisture, and low $\mathrm{CO}_{2}$ levels (Ehleringer et al. 1997; MacFadden et al. 1999). The Arctic ecosystem is dominated exclusively by $C_{3}$ plants but variation in $\delta^{13} \mathrm{C}$ values can still occur within a $C_{3}$ plant ecosystem (Kristensen et al. 2011).

Environmental factors that can affect $\delta^{13} \mathrm{C}$ in $\mathrm{C}_{3}$ plants include temperature, water stress, and light level (Kohn, 2010). Temperature changes can inhibit the effectiveness of $C_{3}$ plant photosynthesis. At higher temperatures, $C_{3}$ plant photosynthesis becomes less effective, primarily due to photorespiration. In these scenarios, Rubisco will preferentially select $\mathrm{O}_{2}$ instead of $\mathrm{CO}_{2}$, resulting in higher $\delta^{13} \mathrm{C}$ fractionation values in the leaves (MacFadden et al. 1999). Similarly, if experiencing water stress, whether through a decrease in rainfall, relative humidity, or soil moisture, the stomata of $\mathrm{C}_{3}$ plants will close, preventing $\mathrm{CO}_{2}$ exchange creating higher $\delta^{13} \mathrm{C}$ values in the leaves (Kohn, 2010). Lastly, light availability will cause a similar reaction as stomata will also close during low light causing increased fractionation (Van der Merwe \& Medina, 1989).

For terrestrial mammals, food is the primary source of carbon. Their tissue reflects the plants that are consumed during their tissue growth with a physiological and trophic level offset (Koch et al. 1992). The stable isotopes of a mammal's tissue are differentiable depending on the plants consumed and the environment within which the 
plants are grown (Cerling et al. 1997). Most herbivorous mammals will have $12-14 \%$ o higher $\delta^{13} \mathrm{C}$ value in their tissue over their preferred plant group (i.e. C3 or C4 plants) (Koch et al. 1992; Cerling et al. 1997; Cerling \& Harris 1998; MacFadden et al. 1999). Between trophic levels most mammals have a $1-2 \%$ enrichment in $\delta^{13} \mathrm{C}$ values with higher degrees of variation in tertiary and quaternary diets (specifically in collagen tissue) (Codron et al. 2017; Kelly, 2000; DeNiro \& Epstein, 1981; Tieszen et al. 1983; Tieszen \& Boutton, 1989; Hobson et al. 1996). From our understanding of trophic levels, $\delta^{13} \mathrm{C}$ values within plants and physiological effects, we can infer their dietary and habitat preferences by studying the $\delta^{13} \mathrm{C}$ values of their various tissues. (DeNiro \& Epstein, 1981; Tieszen et al. 1983; Tieszen \& Boutton, 1989; Hobson et al. 1996).

\subsubsection{Nitrogen: $\delta^{15} \mathrm{~N}$}

Like carbon, nitrogen has two naturally occurring stable isotopes: ${ }^{14} \mathrm{~N}$, which makes up $99.6 \%$ of nitrogen, and ${ }^{15} \mathrm{~N}$ comprising the remaining $0.4 \%$ (Koch, 2007; Bleam, 2017). Unlike carbon, the variation in $\delta^{15} \mathrm{~N}$ within a terrestrial ecosystem is not defined by a single source, like photosynthesis (DeNiro \& Hastof, 1985; Mizutani \& Wada, 1988; Ehleringer \& Rundel, 1989; Kelly, 2000). Therefore, it can be complicated to compare $\delta^{15} \mathrm{~N}$ values across terrestrial food webs, even for individuals of the same species from different geographic regions. Despite this challenge, $\delta^{15} \mathrm{~N}$ values have been shown to be useful, for example, identifying the dietary contributions of different plant types to the terrestrial food chain (Schoeninger \& DeNiro, 1984; Sealy et al. 1987; Ambrose, 1993; Kelly, 2000). 
Many factors can affect nitrogen isotope values in plants, including soil, moisture, temperature, altitude, latitude, atmospheric nitrogen deposition, and the nitrogen fixing bacteria within the plants (Koch, 2007; Nadelhoffer \& Fry, 1994; Högberg, 1997; Handley et al. 1999; Martinelli et al. 1999). The moisture content and temperature of a soil impacts how nitrogen is processed within it altering the degree of which nitrification, ammonification, and leaching occur (Martinelli et al. 1999). From this relationship, $\delta^{15} \mathrm{~N}$, in soil and subsequently plants, has a negative correlation with moisture and positive correlation with temperature (Rabanus-Wallace et al. 2017; Ambrose, 1991; Shearer et al. 1978; Mariotti et al. 1980). In the cold wet ecosystem of the Arctic, $\delta^{15} \mathrm{~N}$ within plants and soil is relatively low. This is particularly true in the permafrost regions where low soil temperatures cause low mineralization rates thus limiting the availability of inorganic nitrogen (Handley et al. 1999; Stevens et al. 2008). Therefore, the plants that grow in this region are generally poor nitrogen-fixing plants that are not inhibited by this limited resource, plants such as mosses, lichen, graminoid shrubs and a few tree species (Rabanus-Wallace et al. 2017; Mann et al. 2013). $\delta^{15} \mathrm{~N}$ values can vary within the tundra ecosystems through seasonal changes in temperature and moisture levels. Increases in temperature from a season can causes a 2-3\%o enrichment within soil while increased precipitation by a few $100 \mathrm{~mm}$ can cause an inverse affect, a 2-3\% depletion (Craine et al. 2015).

For terrestrial mammals, nitrogen is sourced from consumed foods (primarily dietary protein). The $\delta^{15} \mathrm{~N}$ values of their tissue reflect the consumed foods with a 3$5 \%$ enrichment in $\delta^{15} \mathrm{~N}$ between each trophic level (DeNiro \& Epstein, 1981; Minagwa 
\& Wada, 1984; Kelly, 2000). The 3\%o enrichment between trophic levels is created as a byproduct of metabolism. As an animal metabolizes the nitrogen within their body, ${ }^{14} \mathrm{~N}$ is preferentially used and excreted in the form of nitrogenous waste, creating an enrichment of $\sim 3-5 \%$ in $\delta^{15} \mathrm{~N}$ values (DeNiro \& Epstein, 1981; Kelly, 2000). This fractionation of ${ }^{15} \mathrm{~N}$ in consumer tissues makes $\delta^{15} \mathrm{~N}$ values one of the most important tools for understanding interactions in paleoecosystems (Kelly, 2000; Minagwa \& Wada, 1984; Peterson \& Fry, 1987).

$\delta^{15} \mathrm{~N}$ values are not limited to trophic level reconstruction, they also reflect nutrient and water stress in consumers (Ambrose, 1991; Kelly, 2000; Hobson \& Clark, 1992; Cormie \& Schwarcz, 1996). For example, ${ }^{15} \mathrm{~N}$ enrichment in consumer tissue can be a result of urea-recycling during water stress, such as occurs in ruminants including caribou and other cervids (Kelly, 2000; Sealy et al. 1987).

\subsubsection{Nitrogen: $\delta^{15} \mathrm{~N}$ - Carbon: $\delta^{13} \mathrm{C}$}

Nitrogen and carbon isotope values have been shown to covary positively (Fig. 6).

Though this relationship may not be universal (Kelly, 2000; Mizutani et al. 1991), many studies still use it to determine dietary sources. The positive relationship between $\delta^{15} \mathrm{~N}$ and $\delta^{13} \mathrm{C}$ relates to the relative moisture in the environment (Heaton et al. 1986; Sealy et al. 1987; Kelly, 2000). Differences in temperature, moisture content, and atmospheric $\mathrm{CO}_{2}$ levels cause changes to the dominance of either $\mathrm{C}_{3}$ or $\mathrm{C}_{4}$ plants but also affect the $\delta^{13} \mathrm{C}$ values within the plants (Terri \& Stowe, 1976; Ehleringer et al. 1997; Kelly, 2000; Phelan, 2014) Similarly, temperature and humidity affect nitrogen fixation which also 
impacts the $\delta^{15} \mathrm{~N}$ within plants (Rabanus-Wallace et al. 2017; Ambrose, 1991; Shearer et al. 1978; Mariotti et al. 1980). From our understanding of isotopic fractionation of $\delta^{13} \mathrm{C}$ and $\delta^{15} \mathrm{~N}$ within plants we can make inferences about the environment in which they were formed. For example, throughout Northern Canada, the cold wet ecosystem of the Arctic is dominated by only $\mathrm{C}_{3}$ plants (Kristensen et al. 2011). Here $\delta^{13} \mathrm{C}$ and $\delta^{15} \mathrm{~N}$ values are relatively low, however, the values can change with environmental changes (i.e. seasonal changes), such as increased temperature, moisture, and light level (Heaton et al. 1986; Sealy et al. 1987; Ambrose, 1991; Kelly, 2000; Kohn, 2010). Using animal tissue we look at $\delta^{13} \mathrm{C}$ and $\delta^{15} \mathrm{~N}$ values to infer characteristics of their environment including seasonal changes and habitat (i.e. forests, deserts, tundra, and nearshore/coastal environments) (Hobson \& Welch, 1992; Kelly 2000; Ambrose, 1993; Peterson \& Fry, 1987). 


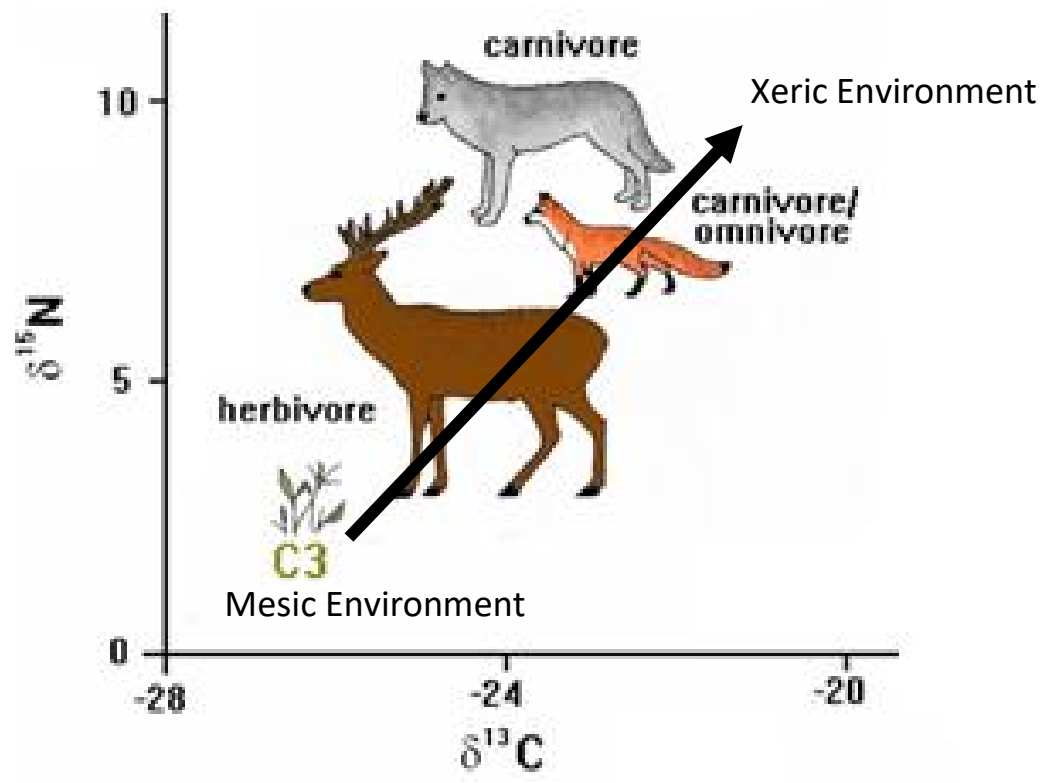

Figure 6. The trophic level and base plant diet impact on nitrogen and carbon stable isotopes (Schulting 1998, modified by S. Svyatko).

\subsubsection{Oxygen: $\delta^{18} \mathrm{O}$}

Unlike carbon and nitrogen, oxygen has three naturally occurring stable isotopes: ${ }^{16} \mathrm{O}$ being the most abundant at $99.76 \%,{ }^{17} \mathrm{O}$ the least abundant at $0.04 \%$, and ${ }^{18} \mathrm{O}$ at $0.2 \%$ (Taylor, 1948). Concentrations of ${ }^{17} \mathrm{O}$ are very low and most studies focus on $\delta^{18} \mathrm{O}$ (Taylor, 1948). Atmospheric oxygen has relatively little effect on isotope values within terrestrial ecosystem (Fry, 2003; Koch, 2007). Water $\delta^{18} \mathrm{O}$ values vary both geographically and temporally, providing an indicator for precipitation and evaporation within an ecosystem (Koch, 2007). Variation occurs geographically as water vapour travels inland from the coast; Rayleigh distillation occurs, ${ }^{18} \mathrm{O}$ in water vapour is lost through rain-out, leaving lower $\delta^{18} \mathrm{O}$ values within the water vapour (Clark \& Fritz, 1997; Hoefs, 2009). The results are a geographical gradient with high-latitudes and coastal 
regions having higher $\delta^{18} \mathrm{O}$ values, a similar effect occurs in regions of high precipitation as more ${ }^{18} \mathrm{O}$ is release through rain-out (Rindsberger et al. 1990; Hoefs, 2009).

$\delta^{18} \mathrm{O}$ values are also broadly correlated with temperature; waters become ${ }^{18} \mathrm{O}$ enriched in warmer temperatures, and depleted in cold (Higgins \& MacFadden, 2004; McCrea, 1950; Bryant et al. 1996). This is largely due to evaporation rates, the lighter ${ }^{16} \mathrm{O}$ is preferentially released into the atmosphere, creating an enrichment in ${ }^{18} \mathrm{O}$ within water during warmer temperatures (Koch, 2007). Evaporation has a greater effect on $\delta^{18} \mathrm{O}$ values in smaller water sources. The effect of evaporation on $\delta^{18} \mathrm{O}$ values is particularly important for the leaves of plants. Increases in temperature cause the evaporation of water within plant leaves, resulting in enrichment in ${ }^{18} \mathrm{O}$. That enrichment then transports throughout the phloem of the plant, affecting $\delta^{18} \mathrm{O}$ values in plant organs (i.e. roots, stems, and branches) (Koch, 2007; Helliker \& Ehleringer, 2000). Evaporation rates can be affected by more than just temperature, increases in relative humidity, precipitation and even wind can alter the amount of evaporation within the environment and the $\delta^{18} \mathrm{O}$ values (Clark \& Fritz, 1997).

If temperatures are above $20^{\circ} \mathrm{C}$, a phenomenon known as the "Amount Effect" occurs. The "Amount Effect" is when $\delta^{18} \mathrm{O}$ values decrease despite increases in temperature. This is a result of a significant increase in precipitation and/or humidity (e.g. the summer rainy season). The increase of precipitation and/or humidity cause a decrease in evaporation within the ecosystem, resulting in a decrease of $\delta^{18} \mathrm{O}$ values in the environment (i.e. within the meteoric water and plants) (Higgins \& MacFadden, 2004; Rozanski et al. 1993; Bard et al. 2002; Straight et al. 2004). In the high Arctic, 
temperatures do not often reach the $20^{\circ} \mathrm{C}$ threshold, however, with climate change it is anticipated that the threshold would be reached more frequently (Higgins \& MacFadden, 2004; Dansgaard, 1964; Rozanski et al. 1993; Straight et al. 2004).

Oxygen isotopes are introduced into the tissues of animals primarily through water intake supplied to the body by diet, drinking, and inhalation, though the latter is negligible (Podlesak et al. 2008). Oxygen isotopes are exchanged with the animal tissue at equilibrium with the body water, in homeotherms (mammals and birds) there is a constant fractionation caused by internal body temperature (Kohn, 1996; Podlesak et al. 2008). Therefore, in terrestrial mammals' variation in $\delta^{18} \mathrm{O}$ values of consumed waters is reflected in vertebrate tissue and can be used to infer seasonal/climatic patterns, migration routes and altitude changes (Koch, 2007).

\subsection{Tissue Development}

As part of my research, stable isotope analysis of oxygen, carbon, and nitrogen was conducted on various tissue types of Rangifer tarandus (caribou). During tissue development, materials consumed through drinking, eating, and breathing are incorporated into new tissues. In principle, the stable isotope values occurring in the environment will be captured in that tissue with little to no additional fractionation, enabling the inference of habitat, diet, and drinking water source. However, skin, bone, teeth, muscle, and hair incorporate stable isotopes from the environment differently due to differences in rates of tissue formation and the physical and chemical processes involved in tissue synthesis (Hedges, 2007; Drucker et al. 2010; Gannes et al. 1997). 
Different types of tissue have different rates of formation and as such reflect different periods of time. Some tissues can also have turnover, meaning new growth and/or degradation (e.g. bone absorption and remodeling). Diagenesis - the physical and chemical change of material - can also alter stable isotope values after prolonged environmental exposure (Macko et al. 1990). As my research involved well-preserved modern tissues, it was not necessary to consider this phenomenon further.

Teeth have been heavily studied and have proven to be particularly useful given that, once fully mineralized, stable isotopes from the environment are no longer incorporated in the tissue (Passey \& Cerling, 2002; Fricke \& O'Niel, 1996; Fricke et al. 1998). In the case of caribou, teeth develop over roughly 6 months and reflect only food consumed during this growth period (Drucker et al. 2012; Kohn, 2004). Bone remodels (i.e. new bone is developed while old bone is absorbed) slowly over time, providing an average of the stable isotopic values of consumed foods over years (Eriksen, 2010; Eriksen et al. 1990; Matsubayashi \& Tayasu, 2019). Antler tissue has not been thoroughly studied but stable isotope values from this tissue may provide unique ecological information, as antler is one of the fastest growing bone (Chen et al. 2009; Goss, 1983; Lincoln, 1992). Antler may provide a high-resolution record of ecology during their relatively brief growth period (months). Yearly re-growth and shedding also make antler a useful and humane tool in studying yearly variations in cervid ecology using stable isotopes.

\subsubsection{Bone}


Antler and bone tissues are largely comprised of the same material, being a composite of protein (mostly collagen) and calcium hydroxylapatite (which binds carbonate and phosphate groups) (Stevens \& O'Connell, 2016). However, there are several distinct differences. The first and primary difference is the speed of growth, with antler tissue undergoing rapid development over a few months in the spring and summer whereas bone can take 3-5 years to fully form (Heckeberg, 2017; Goss, 1983; Pasda, 2009; Skogland, 1985). A second major difference is that long bones contain more spaces to accommodate structures and tissues like blood vessels and marrow, which produce necessary materials for body growth and function. Antlers pull materials out of the body, like calcium and phosphate, but do not provide materials back to the body (Chen et al. 2009). A third difference is that bone, remodels over a period of $\sim 10$ years within large mammals. In contrast, antlers never remodel (Stevens \& O’Connell, 2016; Hedges et al. 2007; Ambrose \& Norr, 1993; Tieszen \& Fagre, 1993).

Bone is remodeled through a two-step process, bone resorption and ossification (Eriksen, 2010; Eriksen et al. 1990). Bone resorption occurs when osteoclasts break down bone tissue into its base minerals and allow the blood stream to transport the material to where it is needed. Ossification is essentially the reverse. Osteoblasts replace cartilage and mesenchyme tissue directly on to the bone where it ossifies to bone tissue (Eriksen, 2010; Komori et al. 1997). For both bone and antler, isotopes will vary during the formation of collagen, carbonates, and phosphates due to an individual's diet (Stevens \& O'Connell, 2016). For bone, the stable isotope values will reflect an individual's intake average over a period of $\sim 10$ years within bone tissue. 


\subsubsection{Teeth}

Teeth grow over a finite period and do not remodel; in this way they are comparable to antlers. The growth rate of a tooth varies from species to species but usually occurs over a 6-12 month period during the early years of the species life, for caribou teeth development occurs over 6 months (Passey \& Cerling, 2002; Drucker et al. 2012; Kohn, 2004). Teeth are comprised of two major parts, the enamel, which is the hard-outer layer, and the dentin, a connective tissue under the enamel. Enamel is mainly comprised of hydroxylapatite. Isotopic variation can be found in carbonate and phosphate substitutions made during enamel formation (Chritz et al. 2009; Koch, 1998; Kohn \& Cerling, 2002). Enamel forms through a process called amelogenesis, this occurs during the Bell stage of tooth development (Fig. 8) (Passey \& Cerling, 2002; Eisenmann, 1985). Amelogenesis occurs in two stages, the secretory stage and maturation. During the secretory stage, ameloblasts surround the forming tooth and secrete an enamel matrix in sequential layers, building the enamel wall. Maturation occurs after the formation of the enamel, starting at the crown of the tooth and moving down towards the root. For isotopic analysis, this maturation stage is the most important. The enamel matrix is slowly mineralized, followed shortly by the tooth eruption (Bronckers, 2017; Josephsen \& Fejerskov, 1977; Takano \& Ozawa, 1980). 


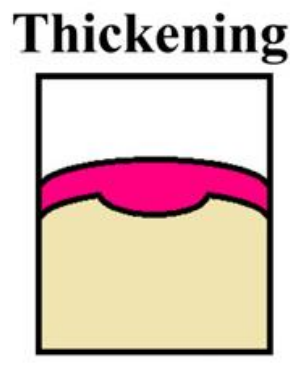

Dental epithelium

Dental mesenchyme
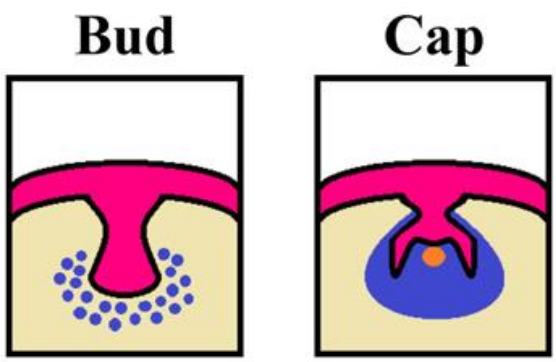

Condensed mesenchyme

\section{Primary enamel} knot
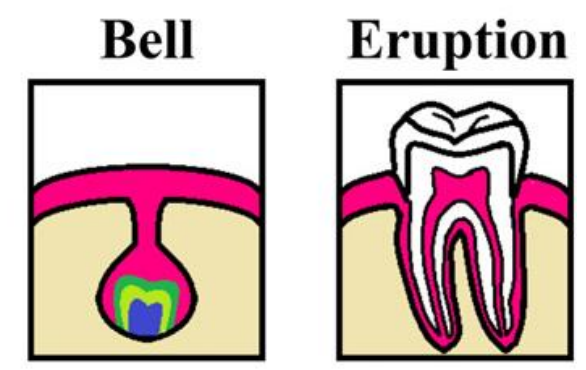

Ameloblasts

\section{Odontoblasts}

Figure 7. Tooth development and process (Amrollahi et al. 2016).

Once the tooth mineralizes, it will no longer have isotopic exchange with the body fluids (Passey \& Cerling, 2002; Lee-Thorpe \& Van der Merwe, 1987; Quade et al. 1992; Bocherens et al. 1996; Zazzo et al. 2000; Cerling et al. 2001). The isotopes within the enamel will reflect the diet consumed during tooth formation, often reflecting the first $6-12$ months of the individual's life (Fricke \& O'Niel, 1996; Fricke et al. 1998).

\subsubsection{Antler}

Antlers occur in members of the deer family Cervidae and, of the 40 extant deer species, 36 grow antlers annually. Cervid antlers vary among species, taking on a wide variety of shapes and sizes, from a simple spike to the large palmate antler of a moose (Goss, 1983). Rangifer tarandus are unique among these 36 extant species as they are the only species where both males and females develop antlers, though female antler growth is not uncommon in the history of mammal evolution (Lincoln, 1992; Schaeffer \& Mahoney, 2001; Roberts, 1996). 
For female caribou, the functional advantages of antler development outweigh the costs (Schaeffer \& Mahoney, 2001; Clutton-Brock, 1982; Kiltie, 1985). Antlers in both male and female caribou, are primarily used for resource competition and intraspecific combat (Schaeffer \& Mahoney, 2001; Clutton-Brock, 1982; Markusson \& Folstad, 1997). Females are unique to males as they carry their antlers through the winter to remove snow cover from subnivean food and to defend food patches (Schaeffer \& Mahoney, 2001; Espmark, 1964; Barrette \& Vandal, 1986, 1990).

Antler growth varies between male and female caribou. Antler growth is triggered by hormonal release that is aligned with the seasonal reproductive cycle. For the males, the gonads release concentrations of testosterone to initiate development, while females have a similar hormonal release during the onset of ovarian activity (Lincoln, 1992). Males begin antler formation in February and March, while females grow their antlers beginning in May and June (Baski \& Newbery, 1987, 1989). Males shed their antlers at the end of the rutting season, which occurs in early winter, while females often shed their antlers when calving in late spring the following year (Shah et al. 2008).

Antler growth is a very fast development process in which hydroxylapatite (i.e. calcium phosphate hydroxylapatite $\left.\mathrm{Ca}_{10}\left(\mathrm{PO}_{4}\right)_{6}(\mathrm{OH})_{2}\right)$, and collagen form a compact bone surrounding a core of cancellous bone. An antler cross-section consists of concentric rings of collagen protecting a series of blood vessels that pull fluid and minerals from the body to sustain fast growth (Chen et al. 2009). Their rapid development and lack of 
remodelling has the potential to result in unique, high resolution stable isotopic records of caribou ecology.

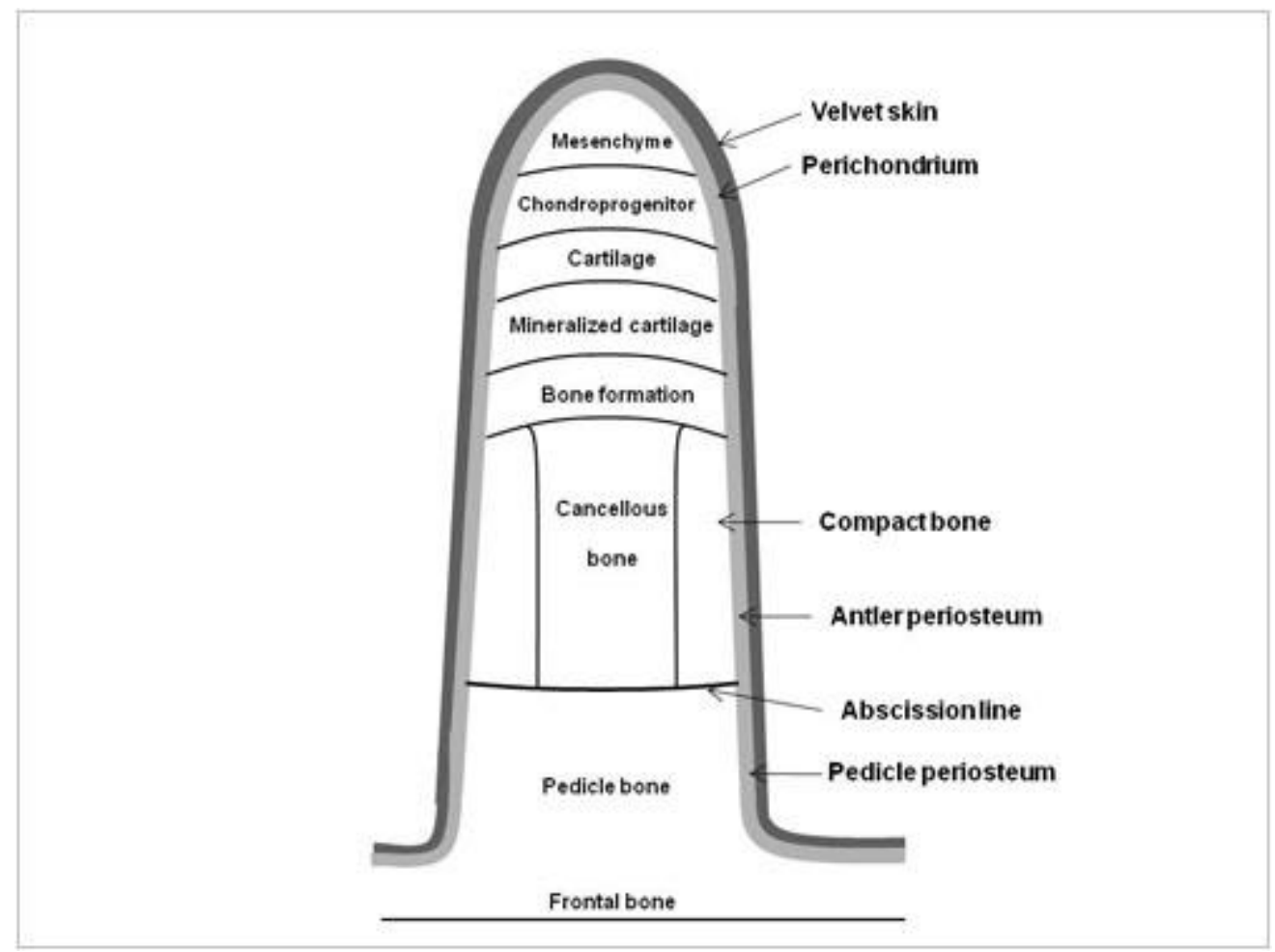

Figure 8. Pedicle bone of initiating the start of antler formation. Upper layers of cartilage mineralize to form antler bone (MSU, 2020 - adapted from Price et al. 2005).

Rangifer tarandus antler development is one of the fastest growing hard tissue known, developing at a rate between $1.7 \mathrm{~cm} /$ day up to $10 \mathrm{~cm} /$ day (Heckeberg, 2017; Goss, 1983). Antler growth begins on the pedicle, a bony platform found in the frontal bone of the skull. A velvet membrane is formed on the surface of the pedicle during antler growth (Fig. 7). This smooth-haired skin has a high density of blood vessels, which aids in rapid growth by supplying a large quantity of nutrients (Krauss et al. 2011; Li et al. 2004). On the tip of the antler, under the velvet membrane, a cap-like area of mesenchymal cells continuously forms new bone tissue. Thus, the tip of the antler is 
made of the youngest material (Krauss et al. 2011; Banks, 1974; Kierdorf et al. 2003; Li et al. 2005; Wislocki, 1942). Once the antler is fully developed, the velvet skin is shed, and the bone has completely developed and will not undergo remodelling (Krauss et al. 2011; Stevens \& O’Connell, 2016).

Antlers will incorporate isotopes during the formation of the compact and cancellous bone (i.e. the collagen, carbonates, and phosphates) through the individual's diet (Stevens \& O'Connell, 2016). This tissue will indicate a dietary time series of their growth period.

\subsection{Thesis Objective}

As highlighted above, caribou are an important species for maintaining the Arctic ecosystem. However, they are being greatly impacted by climate change. My future research goal is to determine if Rangifer tarandus antlers can be used as effective ecological indicators relative to other hard tissues such as bone and teeth using stable isotopes of oxygen, carbon, and nitrogen. Antlers are large, fast growing tissue, that grow and shed annually. They could provide a high-resolution record of the ecological changes that occur during their growth period from the early spring to late summer. In comparison, other tissue such as bone only provides decadal averages. Teeth are excellent resources but only reflect the early stages of life.

My Master's thesis aims to address two main questions: 1) How do isotopic signals on antlers differ from two well-studied hard tissues, teeth and bone and 2) Do stable isotopes vary along the length of the antler? Due to differences in the timing of 
tissue development, it is predicted that isotopic variation will occur among the three tissues. Further, it is predicted that variation will also occur along the growth axis of the antler. If variation along the length of the antler occurs, possible explications for isotopic change could be the seasonal migration of caribou and associated ecological changes or physiological isotopic fractionation. 


\subsection{Methods}

This study was conducted using caribou tissue (i.e. antlers, teeth, and bones) gathered during a Canadian Wildlife Services (CWS) study conducted in the late 1960s (Parker, 1973; Miller D.R., 1973; Miller F.L., 1973; Dauphine, 1973). During the CWS study, 999 caribou were culled, 943 were from the Qamanirjuaq population and 56 from the Beverly population. Culling was conducted to better understand the biology of the caribou population with specific interest in determining age, sex, foraging relationships, growth, and physical and pathological conditions. The project collected caribou over two years between April 1966 to July 1968 to determine seasonal and annual changes to the biology of the caribou. The caribou collected were weighed and their body size measured. A portion of the CWS project studied their rumen contents and mandibles. All samples of skulls, including teeth, antler and bone were carefully scrubbed clean with a stiff-bristle brush after being soaked in hot water for several days. The age and sex of each specimen was determined through dental measurements of the right mandible, with the left being archived (Parker, 1973). The Canadian Museum of Nature housed the samples after the data collected.

The CWS study has allowed me to minimize the variables between my selected samples. A total of 15 caribou were selected from the Qamanirjuaq population, all available caribou culled during the September 1967 collection period, specifically between September $15^{\text {th }}$ and the $21^{\text {st }}$. The 15 individual sample size was selected to ensure that antlers could be thoroughly analyzed with samples taken every $3 \mathrm{~cm}$ along 
the length. The selected caribou were all male, approximately 50 months in age, and of similar weight and body size. To minimize migration differences, all selected caribou were understood to be from the same herd (i.e. the Churchill herd) (Fig. 3). A detailed description of the population, range, habitat, migration routes, and diet are provided in section 1.3 .

\subsection{Samples}

All specimens selected were housed at the Natural Heritage Campus of the Canadian Museum of Nature. Table 2 provides summary information on the selected caribou that were included in my study.

Table 2: List of samples containing collection date, location and specimen size as recorded by Canadian Wildlife Services.

\begin{tabular}{|c|c|c|c|c|c|c|c|c|c|}
\hline $\begin{array}{l}\text { CMN } \\
\text { Catalogue } \\
\text { Number }\end{array}$ & $\begin{array}{l}\text { Date } \\
\text { Collected }\end{array}$ & Latitude & Longitude & $\begin{array}{l}\text { Age } \\
\text { (M) }\end{array}$ & $\begin{array}{l}\text { Weight } \\
\text { (Ibs) }\end{array}$ & $\begin{array}{l}\text { Total } \\
\text { Length } \\
\text { (cm) }\end{array}$ & $\begin{array}{l}\text { Tail } \\
\text { (cm) }\end{array}$ & $\begin{array}{l}\text { Hind } \\
\text { Foot } \\
\text { (cm) }\end{array}$ & $\begin{array}{l}\text { Ear } \\
\text { (cm) }\end{array}$ \\
\hline CMNMA 39079 & $\begin{array}{l}1967-09- \\
17\end{array}$ & 61.15 & -95.4167 & 39 & 218 & 172 & 12 & 49 & 12 \\
\hline CMNMA 39090 & $\begin{array}{l}1967-09- \\
18\end{array}$ & 61.25 & -95.35 & 59 & 283 & 188 & 14.5 & 56 & 12.5 \\
\hline CMNMA 39102 & $\begin{array}{l}1967-09- \\
18\end{array}$ & 61.25 & -95.35 & 51 & 258 & 180 & 14.5 & 53 & 12 \\
\hline CMNMA 39104 & $\begin{array}{l}1967-09- \\
18\end{array}$ & 61.25 & -95.35 & 54 & 277 & 178 & 12.5 & 57 & 11.5 \\
\hline CMNMA 39120 & $\begin{array}{l}1967-09- \\
19\end{array}$ & 61.25 & -95.3167 & 39 & 241 & 168 & 12 & 53 & 12 \\
\hline CMNMA 39121 & $\begin{array}{l}1967-09- \\
19\end{array}$ & 61.25 & -95.3167 & 51 & 221 & 169 & 17 & 55 & 13.5 \\
\hline CMNMA 39132 & $\begin{array}{l}1967-09- \\
19\end{array}$ & 61.25 & -95.3167 & 51 & 260 & 185 & 16 & 54.5 & 11 \\
\hline CMNMA 39145 & $\begin{array}{l}\text { 1967-09- } \\
21\end{array}$ & 61.2 & -95.25 & 51 & 288 & 187 & 14 & 56.5 & 13 \\
\hline CMNMA 39148 & $\begin{array}{l}1967-09- \\
21\end{array}$ & 61.2 & -95.25 & 51 & 274 & 182.5 & 14 & 56.5 & 12 \\
\hline CMNMA 39149 & $\begin{array}{l}\text { 1967-09- } \\
21\end{array}$ & 61.2 & -95.25 & 51 & 283 & 175 & 14.5 & 53 & 13 \\
\hline CMNMA 39151 & $\begin{array}{l}1967-09- \\
21\end{array}$ & 61.2 & -95.25 & 51 & 281 & 182 & 16 & 56.5 & 13 \\
\hline CMNMA 39107 & $\begin{array}{l}1967-09- \\
19\end{array}$ & 61.21667 & -95.0833 & 51 & 268 & 176 & 10.5 & 53.5 & 12 \\
\hline
\end{tabular}




\begin{tabular}{|l|l|l|l|l|l|l|l|l|l|}
\hline CMNMA 39108 & $\begin{array}{l}1967-09- \\
19\end{array}$ & 61.21667 & -95.0833 & 51 & 270 & 180 & 12 & 53 & 12 \\
\hline CMNMA 39110 & $\begin{array}{l}1967-09- \\
19\end{array}$ & 61.21667 & -95.0833 & 39 & 284 & 182 & 10 & 52 & 11 \\
\hline CMNMA 39136 & $\begin{array}{l}1967-09- \\
21\end{array}$ & 61.21667 & -95.0833 & 51 & 342 & 182 & 11 & 54 & 13 \\
\hline
\end{tabular}

\subsection{Isotope Sampling}

Samples for stable isotope analysis were taken along the length of one antler as well as from the mandible (jawbone) and third lower molar of each specimen (for a total of 15 specimens). The third lower molar was selected for this study as it is the final tooth to erupt, indicating a fully mature adult. For each of the 15 antlers, samples were taken at the burr of the antler and then sequentially every $3 \mathrm{~cm}$ to the tip of the antler. Samples were also collected at approximately the middle of each tine (Fig. 9).

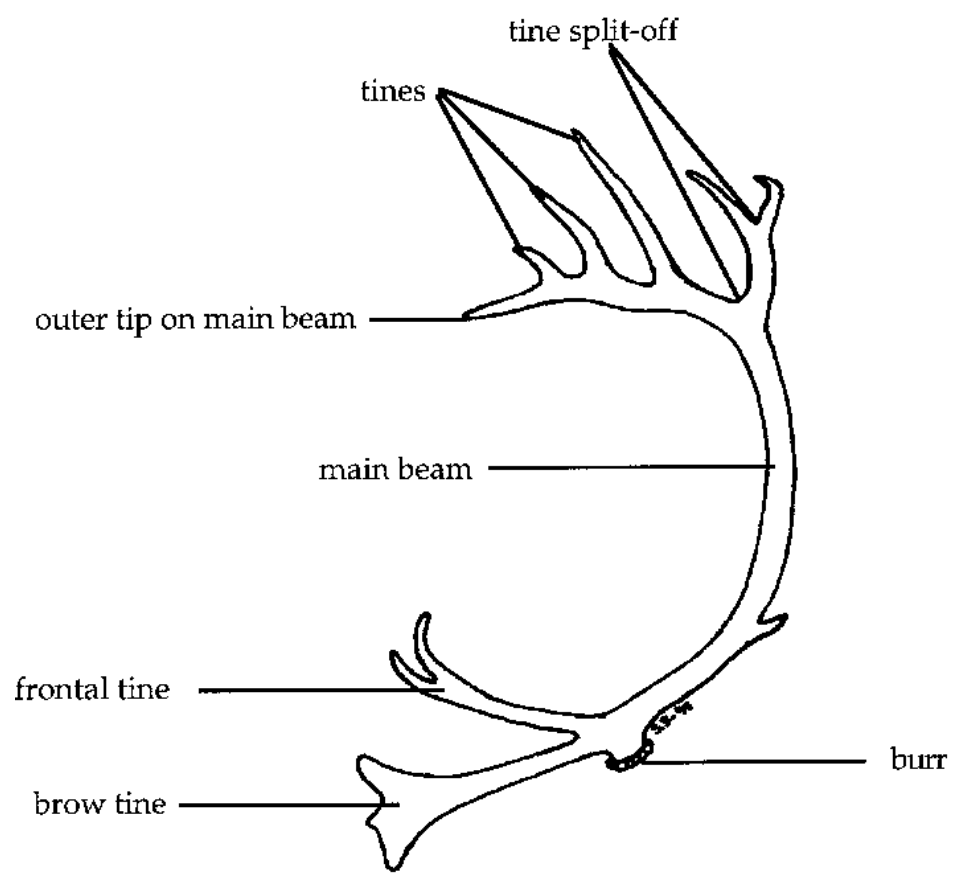

Figure 9: Antler structure and anatomical nomenclature (Markusson \& Folstad, 1997). 
One mandible sample was taken from the middle of the jawbone for each specimen. Three samples of tooth enamel were collected along the third lower molar from root to crown, with approximately $3 \mathrm{~mm}$ between each sample. Collecting enamel was done meticulously to avoid the addition of dentin to the sample. A Dremel (C) tool was used to collect the samples (8050 Micro and 8220 12Vmax High Performance Cordless). Prior to sampling, the Dremel (c) tool was used to remove a surface layer (a few microns) to eliminate potential contaminants. It should be noted that all specimens have been stored at the museum since they were collected, and no environmental contamination is expected. Six (6) mg of powder was collected for antler and bone sampling, while approximately 1-2 mg was collected for tooth enamel sampling.

\subsubsection{Carbonate chemical pre-preparation}

Isotopic chemical pre-preparation procedures followed the standard methods for isolating carbonate (O'Connell et al. 2001; Longin, 1971). $1 \mathrm{ml}$ of 2-3\% $\mathrm{NaOCl}$ (bleach) was added to $3 \mathrm{mg}$ of bone powder to isolate carbonate tissue. Samples were agitated then left to sit in a refrigerator for 24 hours. Samples were then placed in a centrifuge to separate powdered bone/enamel/antler from bleach. The separated liquid was then aspirated, and new $\mathrm{NaOCl}$ solution was added. After another 24 hours of refrigeration, the samples were centrifuged and the $\mathrm{NaOCl}$ solution aspirated. To ensure no bleach remained, the powder samples were washed with deionized water. The sample wash was conducted by adding approximately $1 \mathrm{ml}$ of deionized water, agitating the sample, centrifuging, and aspirating the water. The whole process was repeated five times 
adding $1 \mathrm{ml}$ of deionized water each time. Standard sampling procedure suggests adding $0.5 \mathrm{ml}$ of $1 \mathrm{M}$ acetic acid buffered with calcium acetate to a pH of 5 (Longin, 1971; Koch et al. 1997). The acetic acid protocol is designed for fossilized bone and teeth, as a necessary step to eliminate exogenous carbonate contamination (i.e. weathering). However, antler tissue is made of fine crystals smaller than bone (Chen et al. 2009). The acetic acid was too strong and dissolved all powdered antler material. Since the current samples are modern, I did not expect exogenous carbonate contamination. Therefore, acetic acid treatment was unnecessary.

Finally, samples were placed in a dry oven overnight to remove remaining water. The isolated carbonate tissue was sent to the University of Western Ontario to be placed in a a Thermo Finnigan Delta ${ }^{\text {plus }} \mathrm{XL}$ Isotope Ratio Mass Spectrometer interfaced with GasBench, Costech EA , GC/C, and PreCon peripherals to determine $\delta^{13} \mathrm{C}$ and $\delta^{18} \mathrm{O}$ isotope values.

\subsubsection{Collagen chemical pre-preparation}

The standard isotopic sampling method was followed for collagen with slight modifications (Longin, 1971; O'Connell et al. 2001). 1 - $2 \mathrm{mg}$ of bone and antler were weighed out and placed into separate plastic microcentrifuge tubes with $1.5 \mathrm{ml}$ of $0.1 \mathrm{M}$ $\mathrm{HCl}$ solution (initial procedure suggested $1 \mathrm{M} \mathrm{HCl}$ but was reduced to avoid the rapid breakdown of antler powder). Tubes were given aluminum foil caps and placed into a refrigerator for 30 minutes to allow the samples to decalcify. Published research procedures suggested a two-day decalcification period but caused the complete 
degradation of antler powder material. The resulting solution was aspirated then rinsed using the same deionized water washing technique as the carbonate sample preparation. Samples were placed in the freeze dryer overnight to remove remaining water. Alterations to the typical collagen preparation procedure were made as studies initially suggested the addition of a petroleum ether wash to defat bone material. From research by Chen et al. (2009), I deemed that antlers did not contain enough fatty tissue for this procedure. Defatting can also affect the nitrogen isotopes (Logan \& Lutcavage, 2008; Elliott \& Elliott, 2016). As such, I opted to remove the defatting process for both bone and antler. Samples were then placed in a freeze dryer overnight.

The collagen was isolated for each sample the tissue was sent to the University of Western Ontario to be placed into a Thermo Finnigan Delta ${ }^{\text {plus }}$ XL Isotope Ratio Mass Spectrometer interfaced with GasBench, Costech EA, GC/C, and PreCon peripherals to determine $\delta^{13} \mathrm{C}$ and $\delta^{15} \mathrm{~N}$ isotope values.

\subsubsection{Statistical analysis}

Stable isotope values of carbonate tissue in antler, bone, and teeth were compared within an individual to determine tissue difference. A linear regression statistical analysis was then used to determine if there was linear relationship between the stable isotope values and position along the length of the antler. Analysis was conducted comparing carbon and oxygen isotope values to the length of the antler (from carbonate results). Similarly, nitrogen and carbon isotopes were compared over the length of the antler (from collagen results). 


\subsection{Results}

I found significant evidence of change in both carbonate carbon and collagen nitrogen isotope values along the lengths of Rangifer tarandus antlers. While the isotope values along the antlers demonstrated a high degree of variability, this variability provides fascinating insight into the dietary changes known to occur in caribou.

\subsection{Carbonate Isotope Results}

For the carbonate isotopes, I only completed sampling for five individuals for $\delta^{13} \mathrm{C}$ and $\delta^{18} \mathrm{O}$ isotope values (a sixth was started but never finished). As discussed below, stable isotope analysis of carbonate oxygen showed low repeatability. The COVID-19 crisis, which resulted in the shutdown of the stable isotope laboratory, also eliminated the opportunity to consider other possible solutions to produce reliable oxygen values, as such, further sampling focused on the collagen component.

Carbonate $\delta^{13} \mathrm{C}$ values from the three hard tissues tested were as follows. The average $\delta^{13} \mathrm{C}$ value for bone samples was $-9.16 \pm 0.29 \%$; $1 \%$, lower than the overall average $\delta^{13} \mathrm{C}$ value for antler samples (Table 3). The average $\delta^{13} \mathrm{C}$ value for teeth was $8.79 \pm 0.28 \%$, in between the values for antler and bone samples (Table 3). Tooth enamel $\delta^{13} \mathrm{C}$ values shows a trend opposite to antler, decreasing throughout their growth by $1 \%$ from $-9.33 \pm 0.33 \%$ o to $-8.36 \pm 0.14 \%$ (Fig. 13 ).

The carbonate $\delta^{13} \mathrm{C}$ values had a range of $3 \%$ across all five samples; from $-9.26 \%$ (found at the base of Antler D; Fig. 10) to - $6.92 \%$ (found near the tip of Antler B; Fig. 10). The carbonate $\delta^{13} \mathrm{C}$ values increased significantly along the length of the 
antlers for all five individuals (ordinary least squares regression, $p<0.05$; Fig. 10). $\delta^{13} \mathrm{C}$ values started at an average of $-8.76 \pm 0.23 \%$ in the antler burr and increased by $1 \%$ o to an average of $-7.76 \pm 0.51 \%$ at the tip of the antler (Fig 10). Duplicates did not show a significant difference in $\delta^{13} \mathrm{C}$ between samples (averaging $0.22 \pm 0.31 \%$; Fig. 12).

Carbonate $\delta^{18} \mathrm{O}$ values from the three hard tissues experienced a wide degree of variability. The average $\delta^{18} \mathrm{O}$ value for bone samples was $15.21 \pm 1.57 \%$, the oxygen values within bone samples had greater variability than carbon values, ranging from $13.86 \%$ o (on Specimen A; Fig. 14) to $17.59 \%$ (on Specimen E; Fig. 14). The average $\delta^{18} \mathrm{O}$ value for teeth was $16.33 \pm 0.72 \%$, teeth varied roughly $0.96 \pm 0.68 \%$ o between the crown and root values. Much like antler values, tooth $\delta^{18} \mathrm{O}$ values did not show a consistent trend across all 5 samples.

Across all sampled antlers, carbonate $\delta^{18} \mathrm{O}$ values ranged $~ 8 \%$, from 12 to $21 \%$ o (on Antler B \& F respectively; Fig. 11). The carbonate $\delta^{18} \mathrm{O}$ values did not change significantly along the length of the antlers (ordinary least squares regression, $p>0.05$; Fig. 11). $\delta^{18} \mathrm{O}$ values averaged $16.44 \pm 2.23 \%$ o throughout all the antlers. However, there was a high degree of variation in $\delta^{18} \mathrm{O}$ values between duplicate samples (averaging 1.69 $\pm 1.82 \%$ ), suggesting poor reproducibility (Fig. 12 ). 

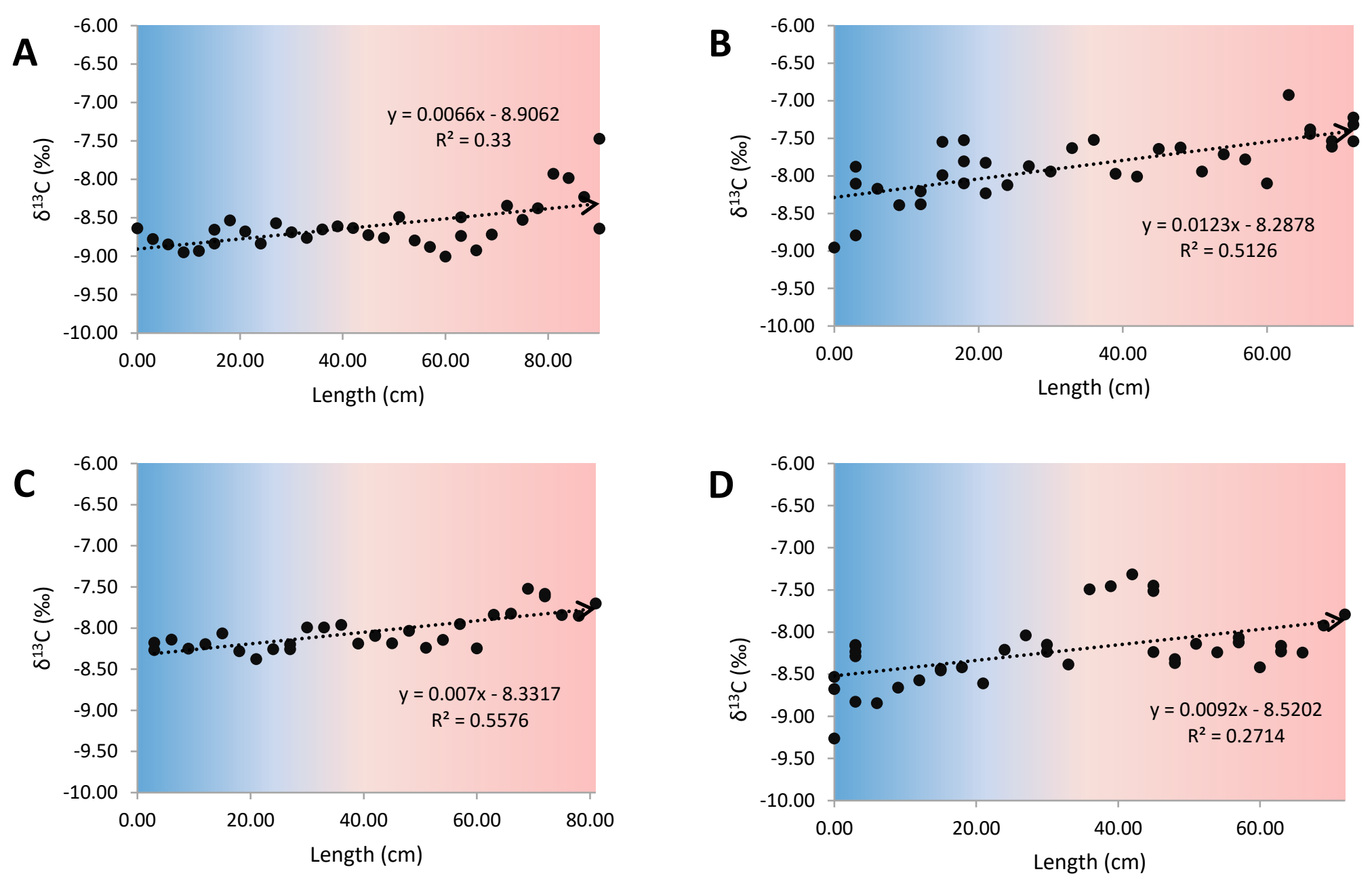

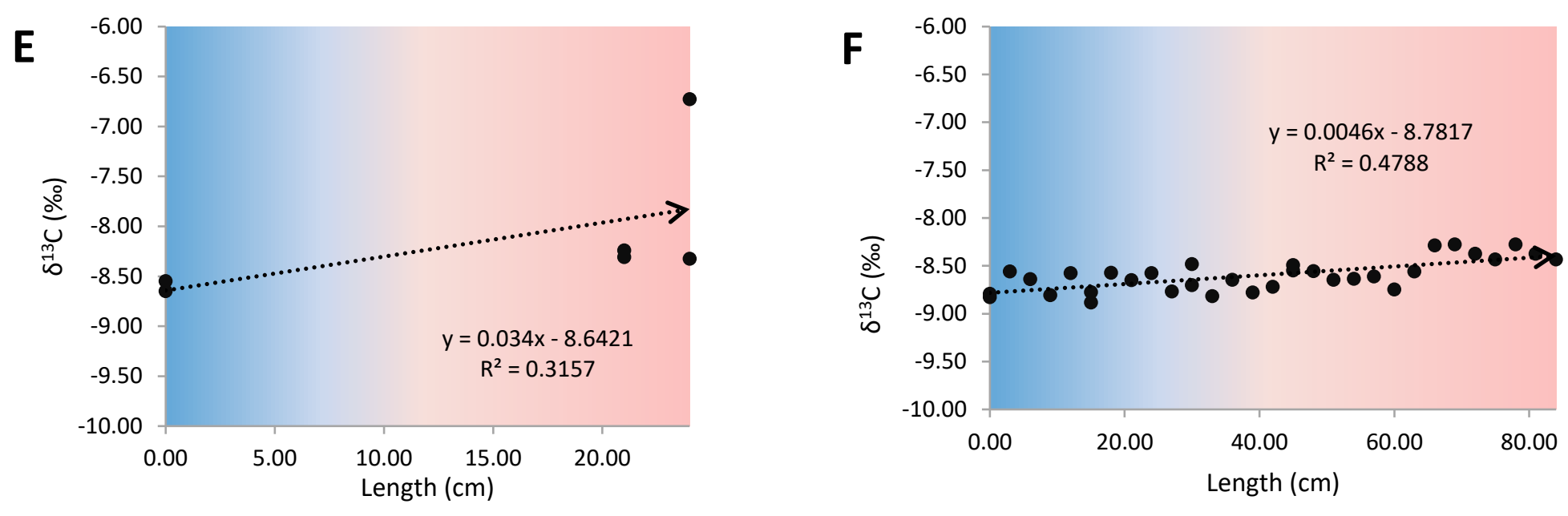

Figure 10. The $X$-axis represents the length of each antler, $0 \mathrm{~cm}$ representing the burr. Linear relationship between antler length and $\delta^{13} \mathrm{C}$ values for carbonate stable isotopes. Linear regression analysis indicate all antlers (with the exception of $E$ due to lack of data) have significant $p$-values ( $A, p=0.000381 ; B, p=9.16 E-07 ; C, p=1.4 E-06 ; D, p=0.000798 ;$ and $F, p=8.18 E-06)$. The $\delta^{13} C$ values ranged from $-9.5 \%$ to $-7.5 \%$ an almost consistent $1 \%$ increase $\delta^{13} \mathrm{C}$ from the base of the antler to the tip. Antlers analyzed: $A=39107, B=39108, C=39145, D=39148, E=39149, F=$ 39151. Colour change representing seasonal temperature changes that occur during antler growth, blue representing the winter season while red represents the summer. 

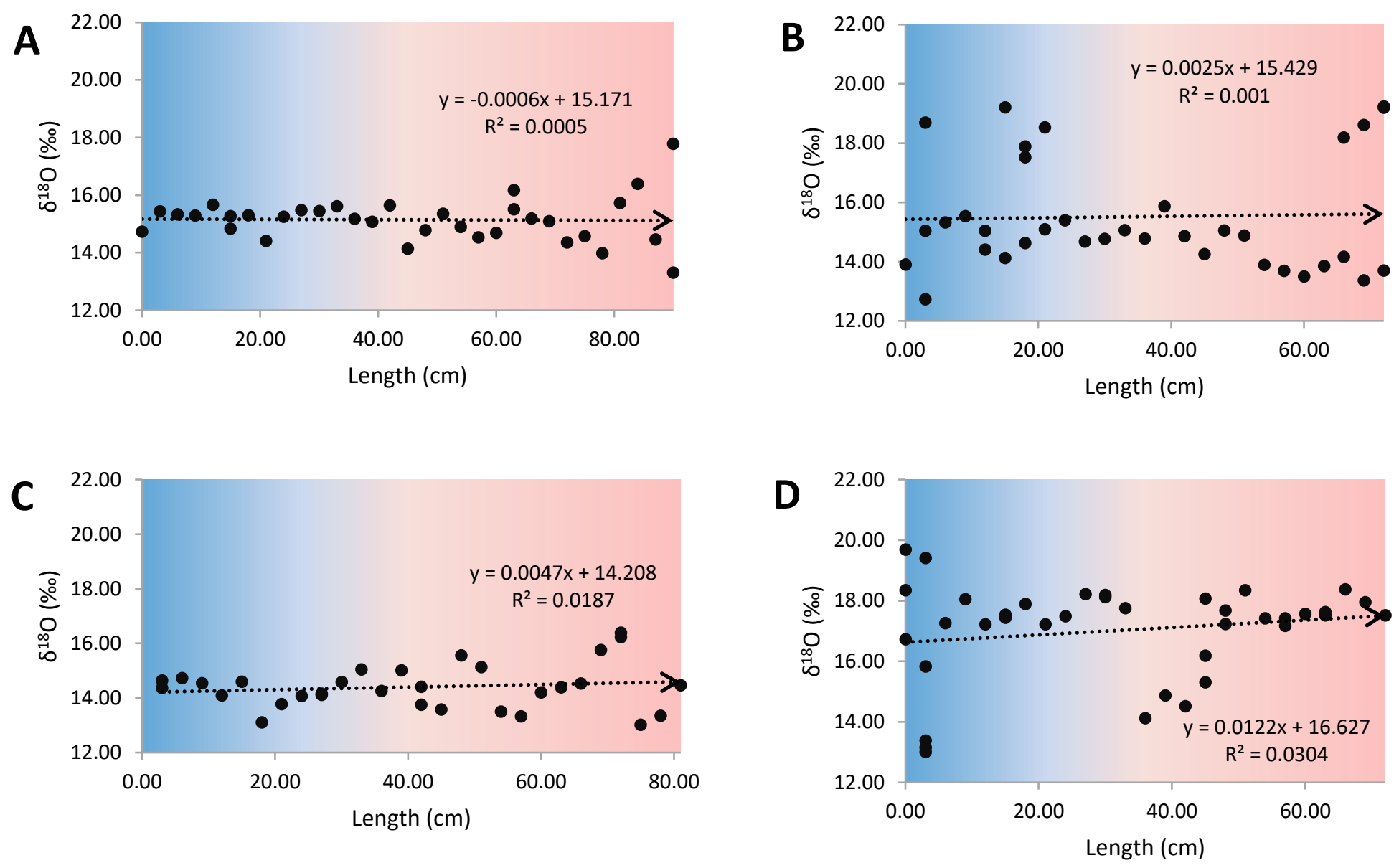

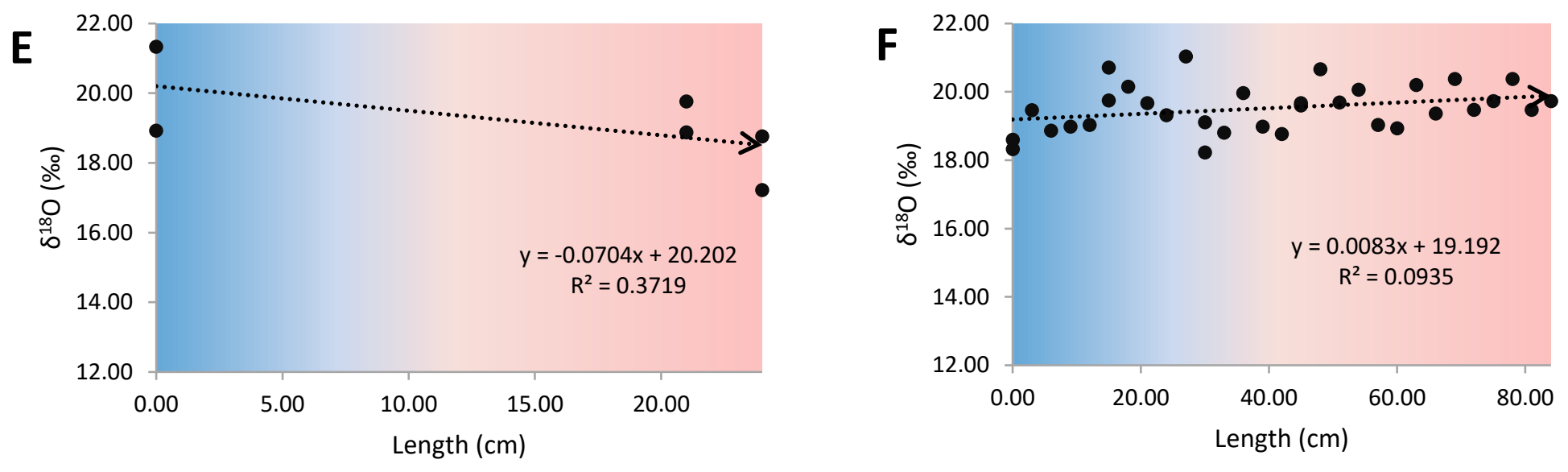

Figure 11. Linear relationship between antler length and $\delta^{18} \mathrm{O}$ values for carbonate stable isotopes. Linear regression analysis for all antlers indicate no significant relationship between antler length and $\delta^{18} \mathrm{O}$ values. The most significant result was sample 39151 (F) with a $p$-value of 0.083592. Antlers analyzed: $A=39107, B=39108, C=39145, D=39148, E=39149, F=39151$. Colour change representing seasonal temperature changes that occur during antler growth, blue representing the winter season while red represents the summer. 

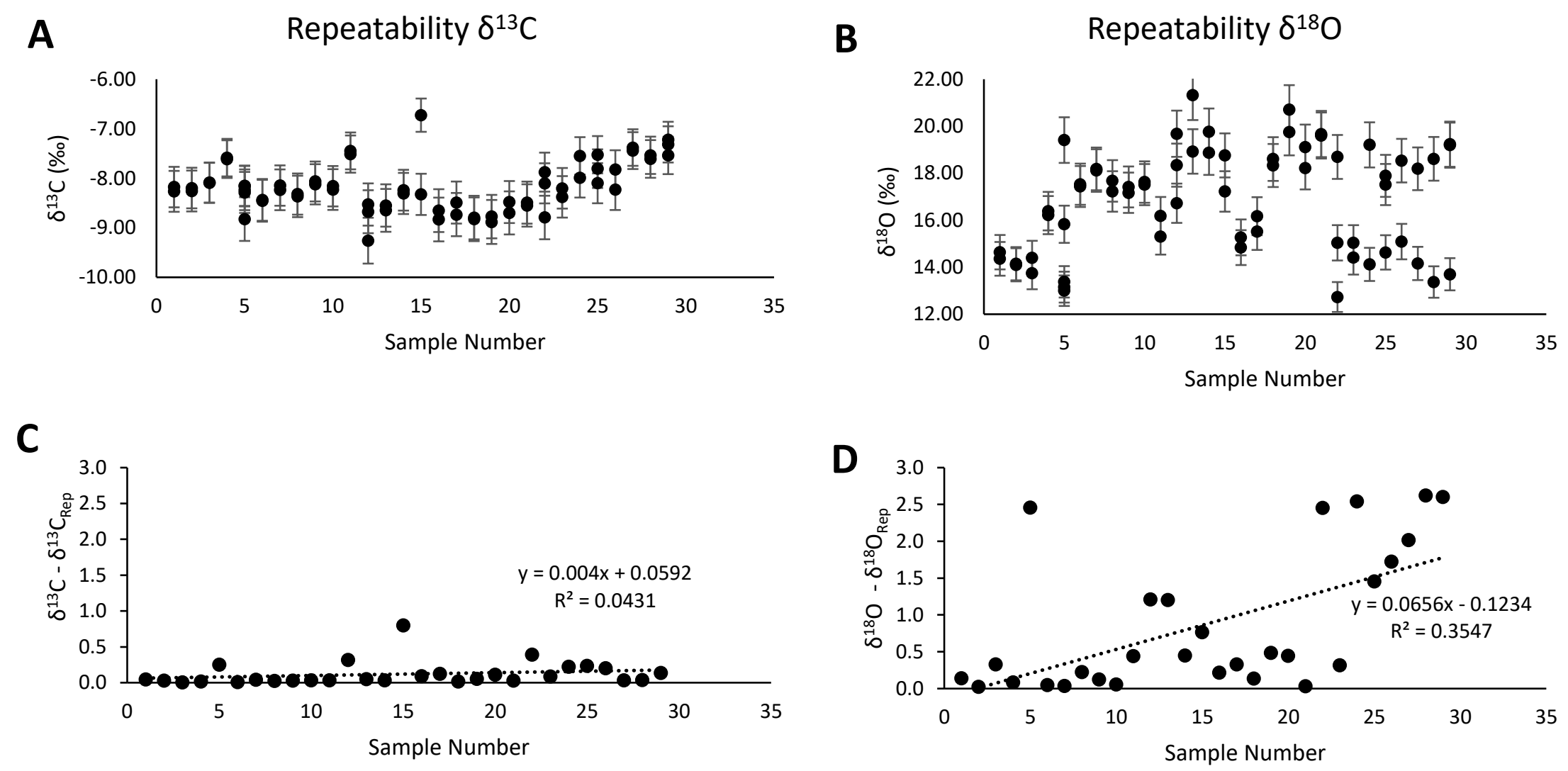

Figure 12. During stable isotope analysis every tenth sample was subject to repeat testing. $A$ and $B$ above are the values of the repeat testing, each sample number represents a different sample tested. $C$ (carbon) and $D$ (oxygen) show the difference between repeated samples for each sample duplicated. There are no correlations between sample numbers as the graph above shows multiple individuals. The only values compared are the repeated stable isotope analysis on one sample. $\delta^{13} \mathrm{C}$ and $\delta^{18} \mathrm{O}$ values of the repeat sampling are indicated strong repeatability, however, $\delta^{18} \mathrm{O}$ values showed poor correlation upon repeat testing. 

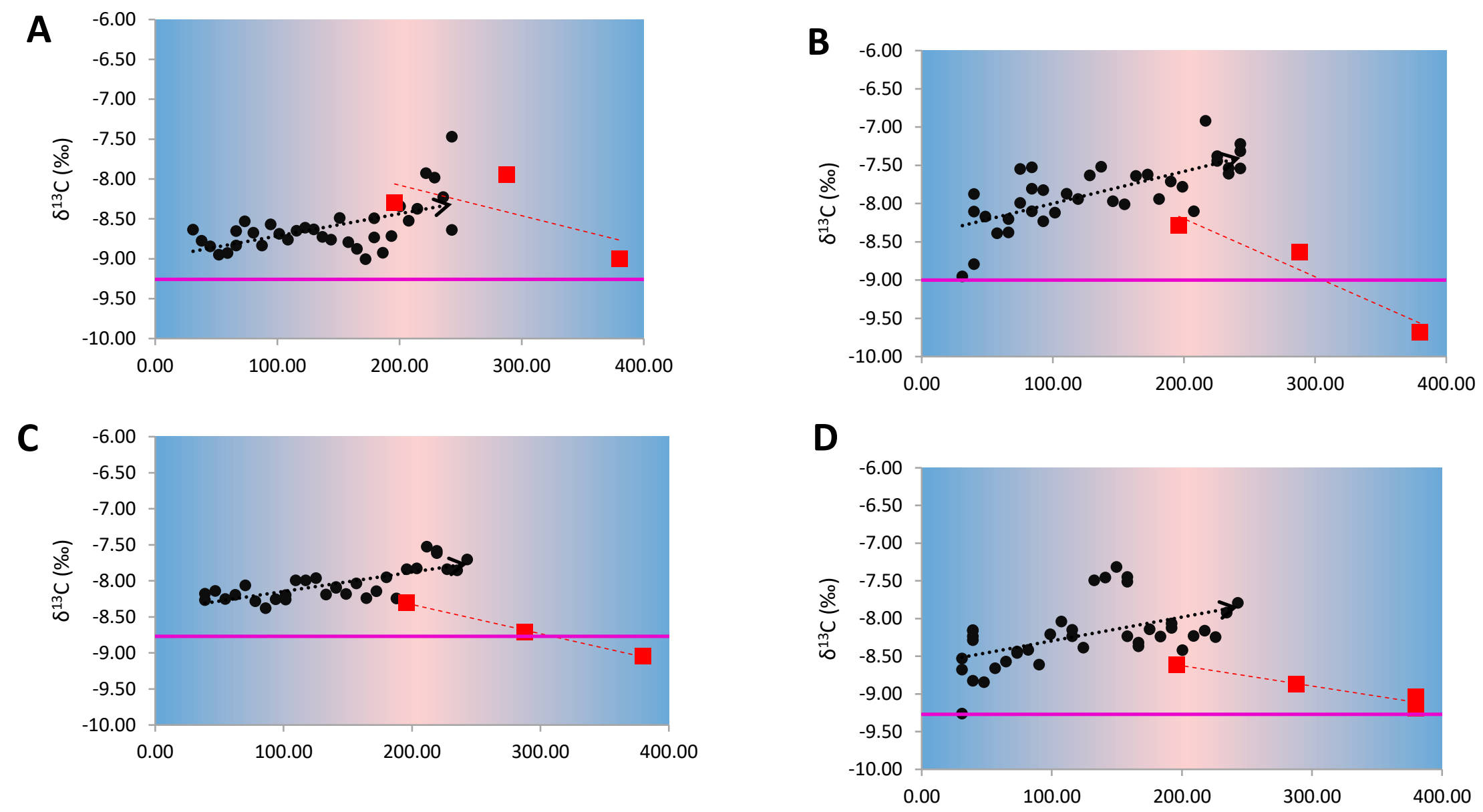


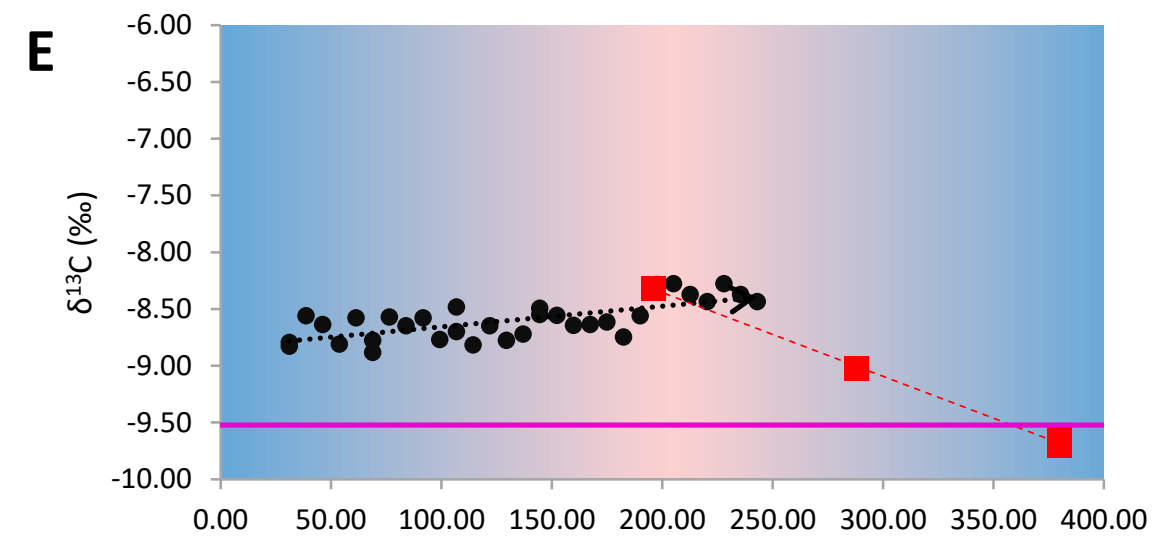

Figure 13. Comparison graphs between the antler $\delta^{13} \mathrm{C}$ isotopes (indicated in black circles, dotted line representing line of best fit), tooth enamel $\delta^{13} \mathrm{C}$ isotopes (indicated in red squares, dotted line representing line of best fit), and mandible (bone) $\delta^{13} \mathrm{C}$ isotopes (indicated by the purple line). For the $x$-axis 0 is set as January $1^{\text {st }}$ the $x$-axis represents just over a year of growth. Each tissue begins formation at a different time of year, antlers begin in the winter, teeth begin in the summer, and bone continuously grows. The colour gradient is used to demonstrate temperature changes during an entire year. Antlers analyzed: $A=39107, B=39108, C=39145, D=39148, E=39151$. 

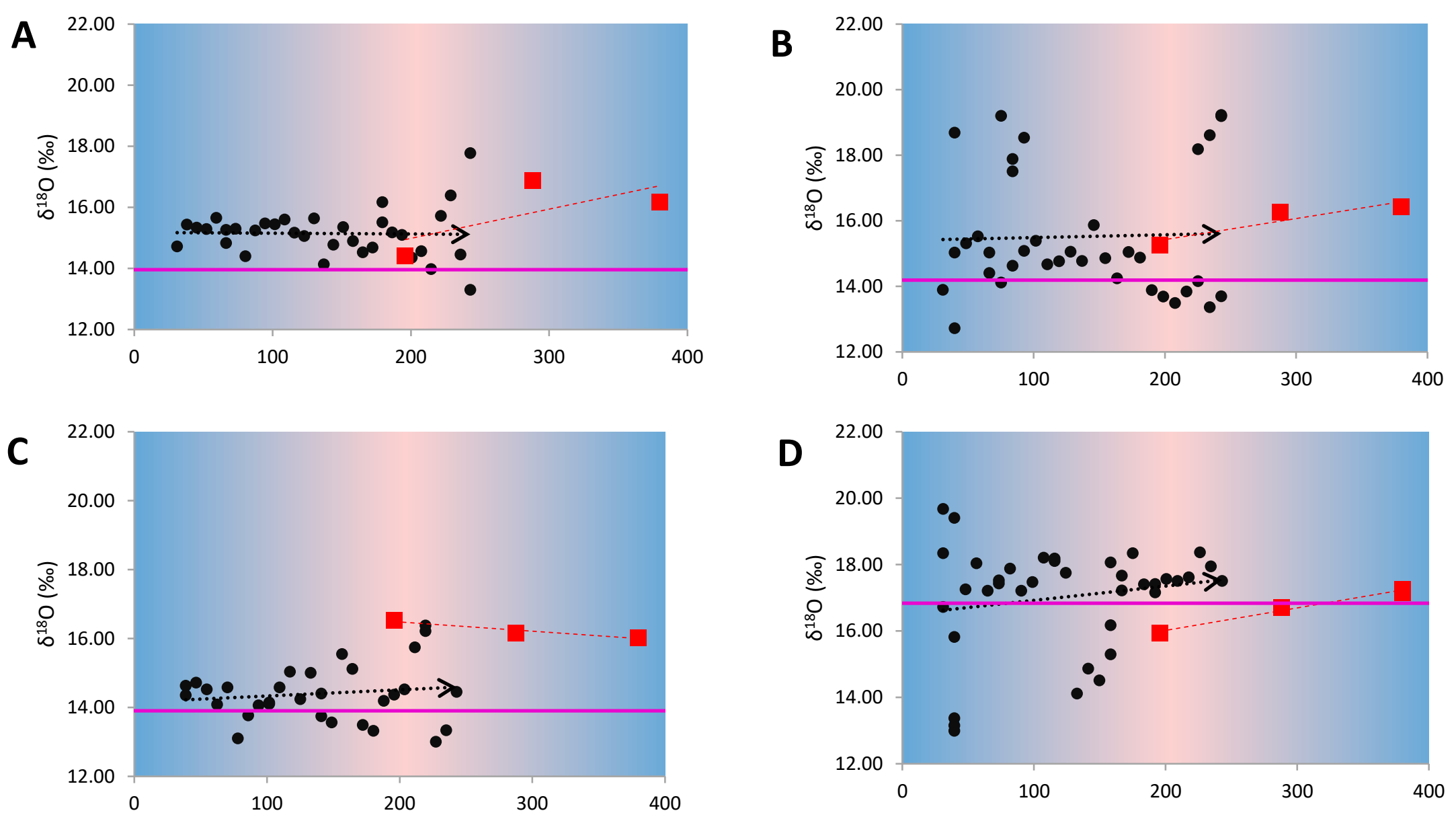


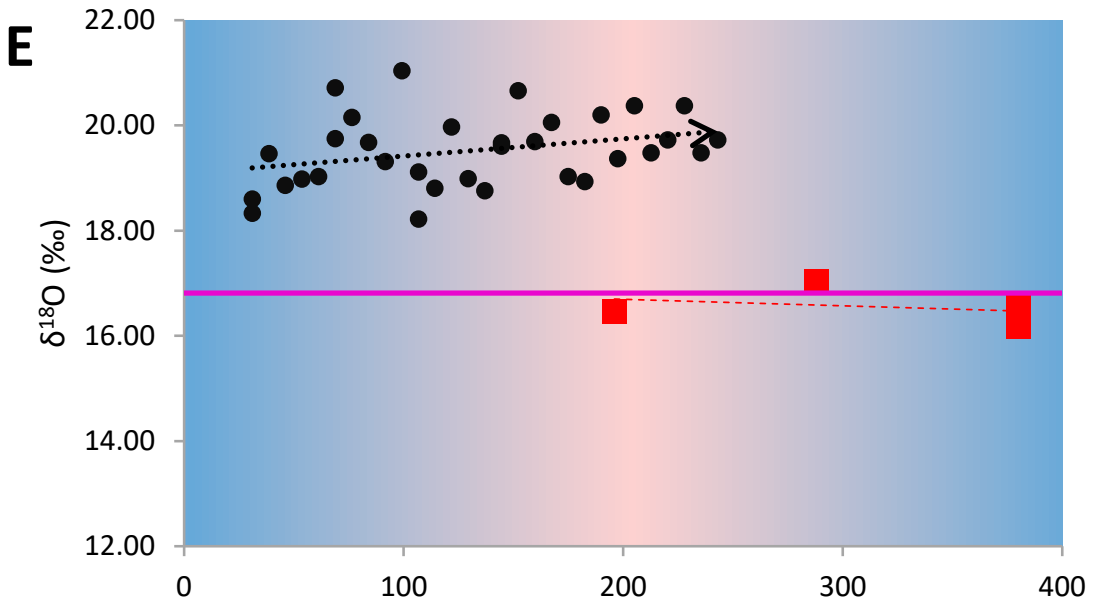

Figure 14. Comparison graphs between the antler $\delta^{18} \mathrm{O}$ isotopes (indicated in black circles, dotted line representing line of best fit), tooth enamel $\delta^{18} \mathrm{O}$ isotopes (indicated in red squares, dotted line representing line of best fit), and mandible (bone) $\delta^{13} \mathrm{O}$ isotopes (indicated by the purple line). For the $x$-axis 0 is set as January $1^{\text {st }}$ the $x$-axis represents just over a year of growth. Each tissue begins formation at a different time of year, antlers begin in the winter, teeth begin in the summer, and bone continuously grows. The colour gradient is used to demonstrate temperature changes during an entire year. The colour gradient is used to demonstrate temperature changes from February (0) to January $15^{\text {th }}(350)$. Antlers analyzed: $A=39107, B=39108, C=39145, D=39148, E=39151$. 
Table 3: Average isotopic values for carbonate $\delta^{13} \mathrm{C} \& \delta^{18} \mathrm{O}$ for mandible (bone), tooth enamel, and antler, including $\delta^{13} \mathrm{C} \& \delta^{18} \mathrm{O}$ values from the antler burr and antler tip, complete table of samples in Appendix 1: Carbonate Stable Isotope Data.

\begin{tabular}{|c|c|c|c|c|c|c|c|c|c|c|c|}
\hline \multicolumn{2}{|l|}{ Sample } & \multicolumn{10}{|c|}{ Carbonate } \\
\hline & & Antler Tip & $\begin{array}{l}\text { Antler } \\
\text { Burr }\end{array}$ & $\begin{array}{l}\text { Antler } \\
\text { Average }\end{array}$ & Bone & $\begin{array}{l}\text { Tooth } \\
\text { Average }\end{array}$ & Antler Tip & $\begin{array}{l}\text { Antler } \\
\text { Burr }\end{array}$ & $\begin{array}{l}\text { Antler } \\
\text { Average }\end{array}$ & Bone & $\begin{array}{l}\text { Tooth } \\
\text { Average }\end{array}$ \\
\hline & & \multicolumn{5}{|c|}{ Carbon $\left(\delta^{13} \mathrm{C} \%\right)$} & \multicolumn{5}{|c|}{ Oxygen $\left(\delta^{18} 0 \%\right.$ ) } \\
\hline A & 39107 & -8.05 & -8.63 & -8.6 & -9.26 & -8.41 & 15.54 & 14.72 & 15.14 & 13.96 & 15.83 \\
\hline B & 39108 & -7.22 & -8.95 & -7.85 & -9.00 & -8.87 & 19.19 & 13.90 & 15.52 & 14.19 & 15.99 \\
\hline C & 39145 & -7.70 & -8.22 & -8.04 & -8.77 & -8.68 & 14.46 & 14.50 & 14.40 & 13.90 & 16.25 \\
\hline D & 39148 & -7.79 & -8.82 & -8.23 & -9.27 & -8.92 & 17.51 & 18.25 & 17.02 & 16.84 & 16.77 \\
\hline $\mathbf{E}$ & 39151 & -8.43 & -8.81 & -8.60 & -9.52 & -9.17 & 19.72 & 18.47 & 19.52 & 16.81 & 16.56 \\
\hline
\end{tabular}




\subsection{Collagen Isotope Results}

For the collagen isotopes, I was only able to sample 12 of the 15 individuals.

Unfortunately, the COVID-19 crisis led to the shutdown of the stable isotope laboratory and the remaining samples could not be analyzed.

Collagen $\delta^{13} \mathrm{C}$ values did not differ between hard tissue of antler and bone (Table 4). The average $\delta^{13} \mathrm{C}$ value for bone samples was $-19.08 \pm 0.34 \%$, only a $0.2 \%$ difference than antler (Table 4).

The collagen $\delta^{13} \mathrm{C}$ values ranged approximately $1 \%$ from -19.68\%o (on Antler $\mathrm{H}$; Fig. 15) to $-18.37 \%$ (on Antler B; Fig. 15). The collagen carbon $\left(\delta^{13} \mathrm{C}\right)$ values did not show consistent trends along the length of the antler. Further, the samples from 12 individuals showed a high degree of variability (Fig. 15; Table 4). Only six antlers showed a significant linear relationship between $\delta^{13} \mathrm{C}$ values and the antler length, though the slopes varied between both positive and negative values (ordinary least squares regression, $p<0.05$; Fig. 15). The average $\delta^{13} \mathrm{C}$ value for antler samples was $-18.88 \pm$ $0.26 \%$ (Table 4 ) and the average difference between burr and antler tip was $0.43 \pm$ $0.29 \%$. Duplicate testing did not show a difference in $\delta^{13} \mathrm{C}$ between samples (averaging $0.14 \pm 0.13 \%$; Fig. 15)

Bone $\delta^{15} \mathrm{~N}$ values ranged from 2.29\%o (on Specimen C; Fig. 16) to $7.00 \%$ (on Specimen G; Fig. 16). There was an average difference of $1.37 \pm 0.84 \%$ o between bone and antler $\delta^{15} \mathrm{~N}$ values (Table 4). 
The collagen $\delta^{15} \mathrm{~N}$ values ranged $~ 5 \%$ from 2.26\%o (on Antler K; Fig. 16) to 6.91\%o (on Antler B; Fig. 16). The collagen nitrogen isotope $\left(\delta^{15} N\right)$ values showed significant change along the length of the antlers (ordinary least squares regression, $\mathrm{p}<$ 0.05; Fig. 16). With the except Antler $\mathrm{K}$, all antlers showed an increase in $\delta^{15} \mathrm{~N}$ values along their length (Table 4). The average difference in $\delta^{15} \mathrm{~N}$ values from the burr to the tip was $1.26 \pm 0.91 \%$ o (Fig. 16 ). $\delta^{15} \mathrm{~N}$ values started at an average of $4.36 \pm 0.72 \%$ o in the antler burr and increased by $1 \%$ o to an average of $5.62 \pm 0.85 \%$ in the tip of the antler (Fig. 16). However, there was a high degree of variation in the $\delta^{15} \mathrm{~N}$ values among individuals. The average $\delta^{15} \mathrm{~N}$ value for antler samples was $5.08 \pm 0.81 \%$ o (Table 4). Duplicate testing did not show a significant difference in $\delta^{13} \mathrm{C}$ between samples (averaging $0.30 \pm 0.36 \%$; Fig. 16).

Collagen $\delta^{13} \mathrm{C}$ values were compared to $\delta^{15} \mathrm{~N}$ values throughout the length of the antler (Fig. 17). No consistent observable trend was seen across all 12 specimens, although certain individuals (i.e. Antlers B, H, I, J, and L; Fig. 17) did demonstrate slight variation between summer and winter values. Summer nitrogen values were higher than winter (Fig. 16) but carbon values did not have a consistent pattern (Fig. 15), as a result, individuals did not display a consistent shift in their $\delta^{13} \mathrm{C} / \delta^{15} \mathrm{~N}$ ratios.

Collagen $\delta^{13} \mathrm{C}$ values were also compared to carbonate $\delta^{13} \mathrm{C}$ values throughout the length of the antlers (Fig. 18). Five antlers were sampled for both collagen and carbonate values and only two had similar observable trends between the two materials (Antler D \& E, Fig. 18). The average difference between collagen $\delta^{13} \mathrm{C}$ values and carbonate $\delta^{13} \mathrm{C}$ values was $10.73 \pm 0.35 \%$. The differences between collagen $\delta^{13} \mathrm{C}$ values 
and carbonate $\delta^{13} \mathrm{C}$ values ranged by $\sim 2 \%$ across all samples with the maximum difference at $11.98 \%$ and the minimum difference at $9.88 \%$ o 

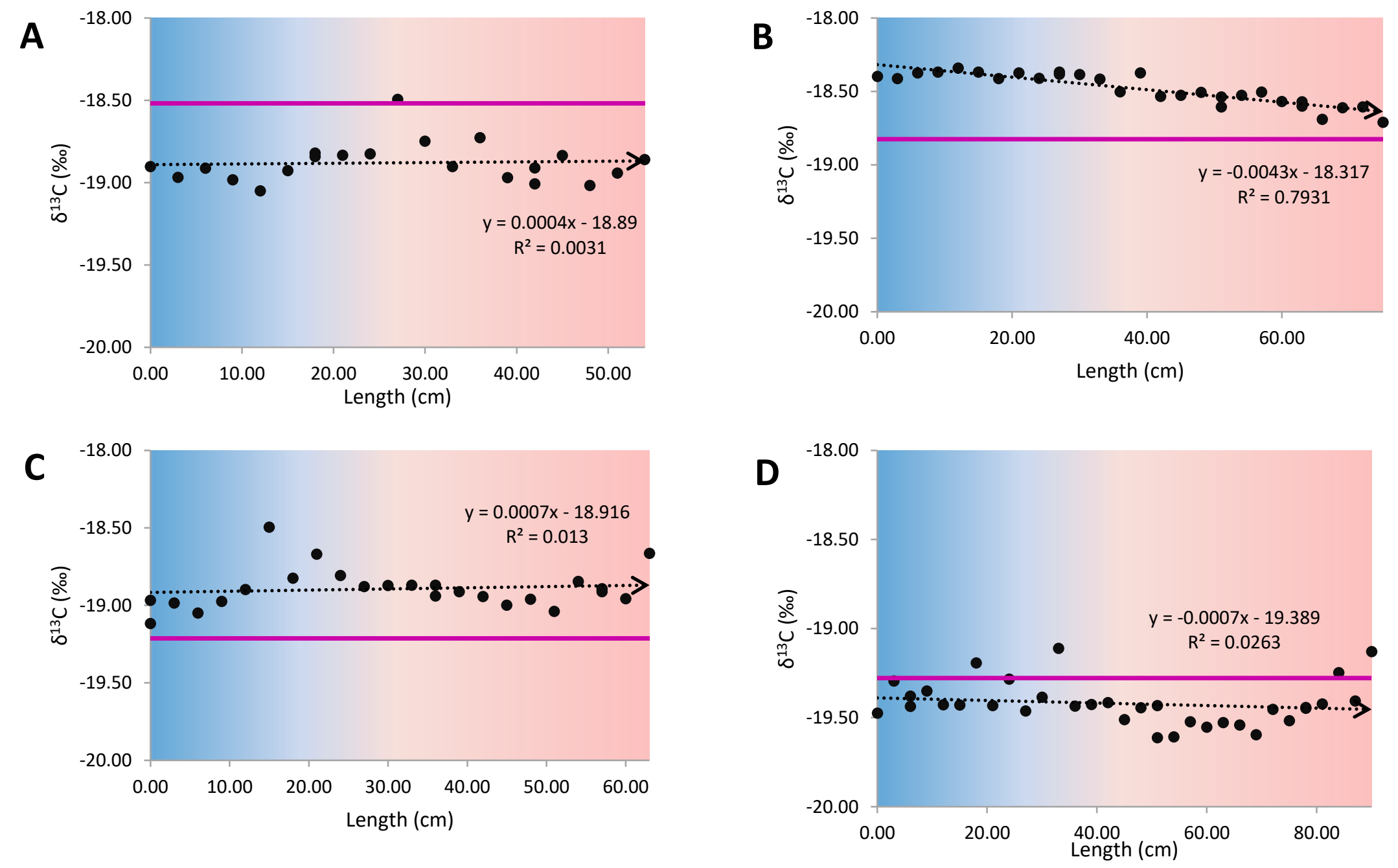

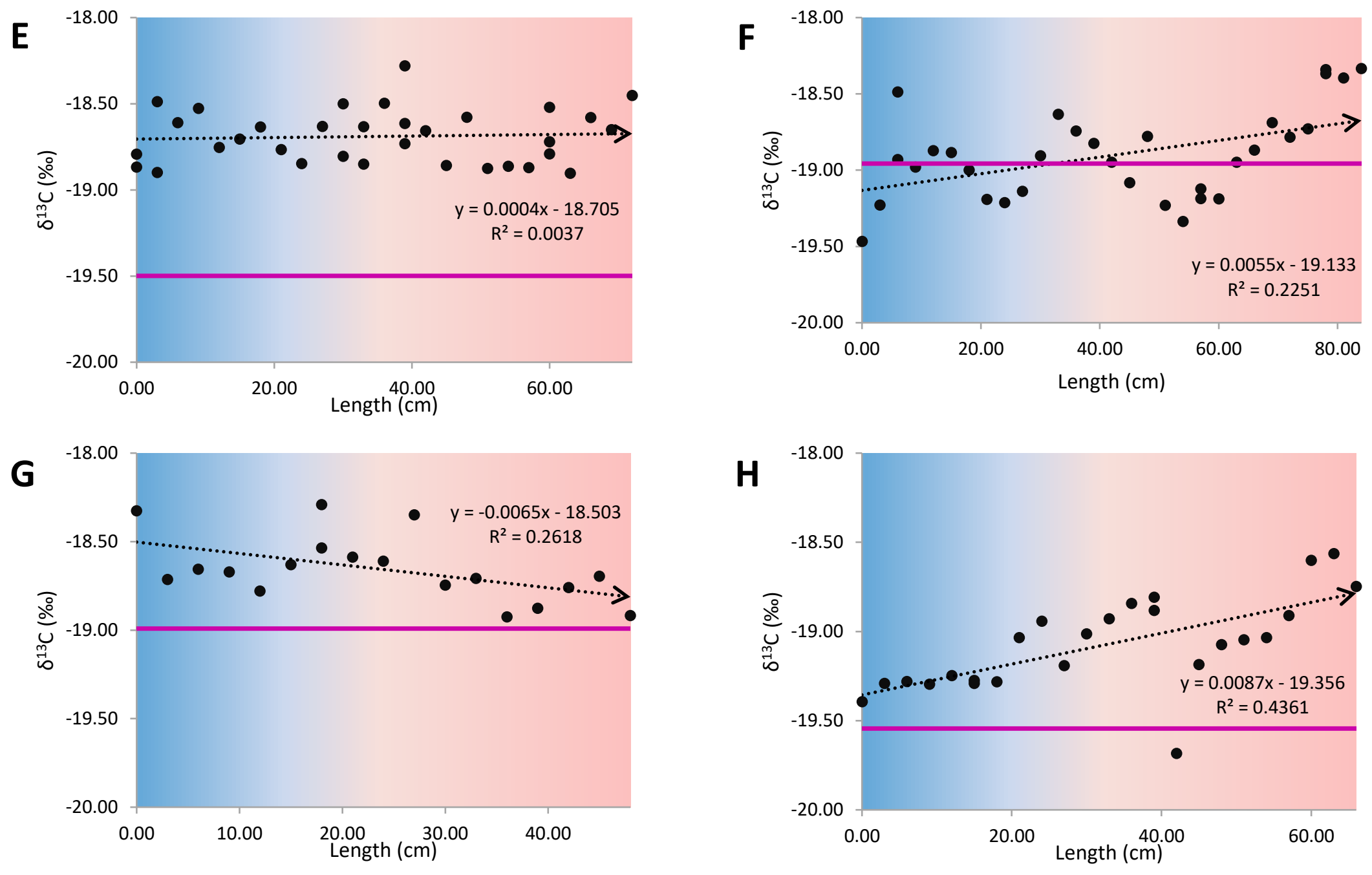

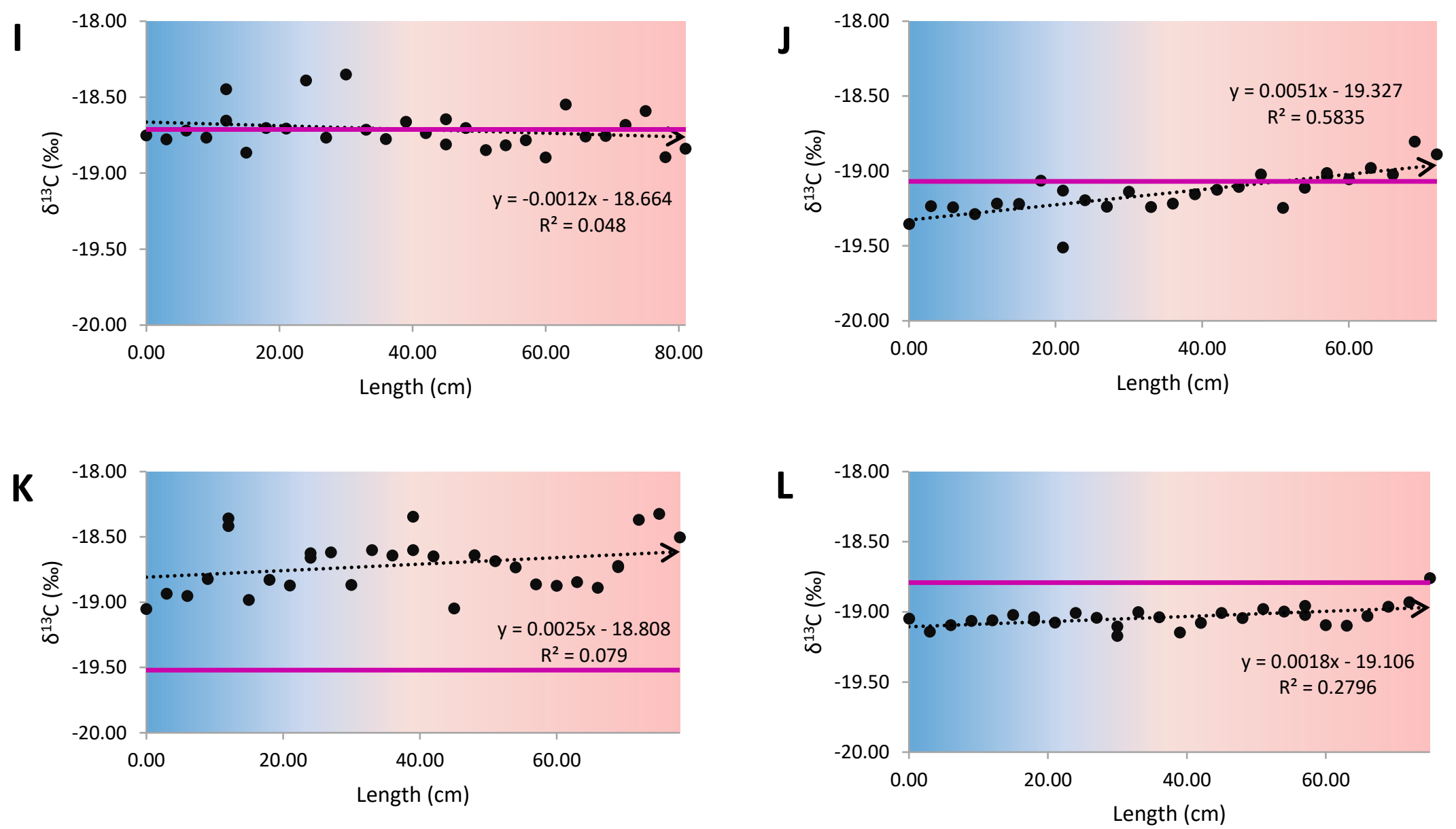

Figure 15. Linear relationship between antler length and $\delta^{13} \mathrm{C}$ values for collagen stable isotopes. Linear regression analysis indicates some antlers follow a linear relationship with significant $p$-values. Antlers following a linear relationship are as follows: $B, p=9.8 E-11 ; F, p=0.006084 ; G, p=$ 0.029982; $H, p=0.000328 ; J, p=3.55 E-6 ; L, p=0.003191$. Antlers analyzed: $A=39079, B=39090, C=30102, D=39107, E=39108, F=39110, G=$ $39120, H=39132, I=39145, J=39148, K=39149, L=39151$. The colour gradient along the graph represents temporal change that occurs during antler growth, blue representing the winter and red the summer. Purple line represents the average bone isotope value. 

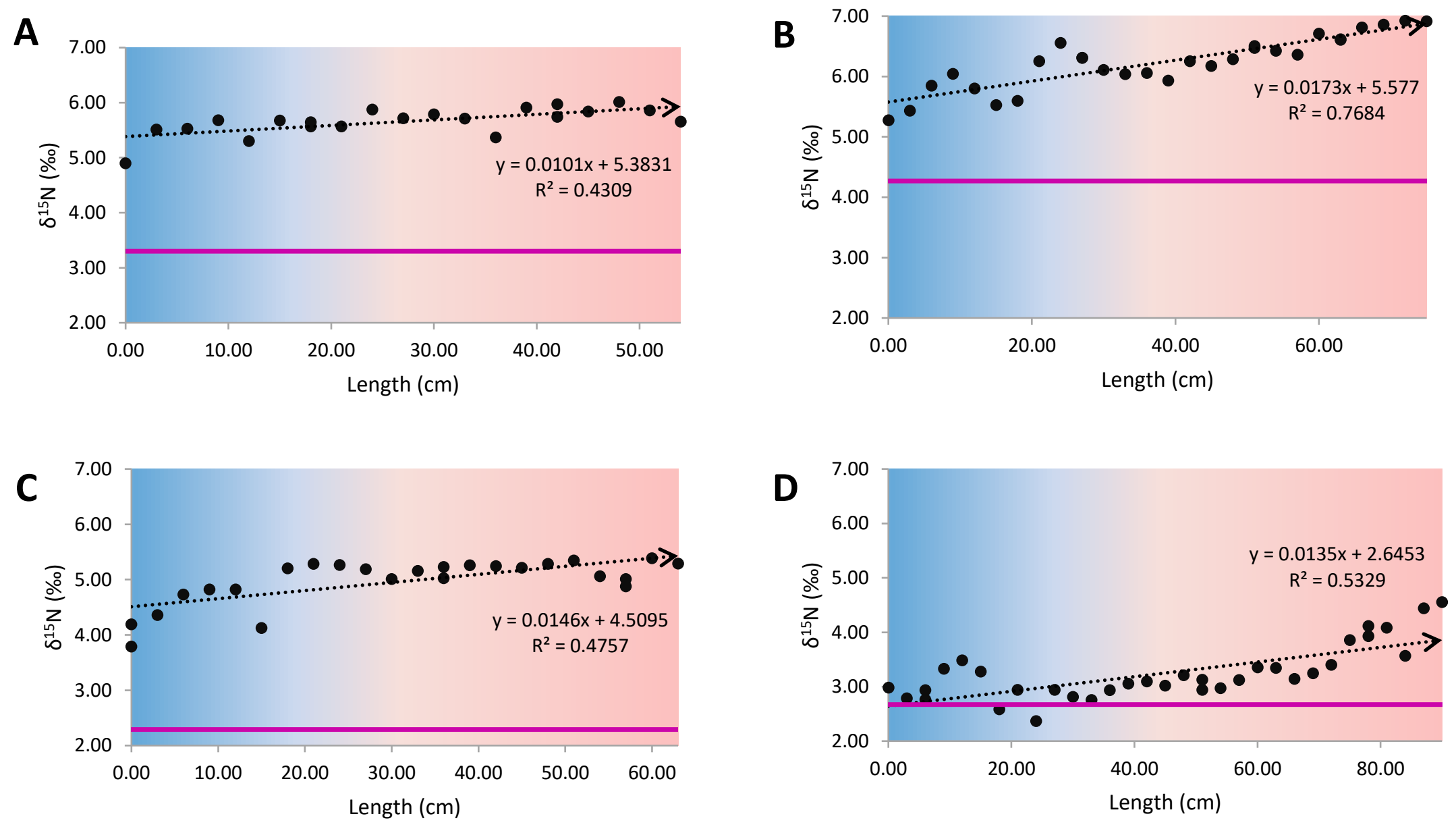

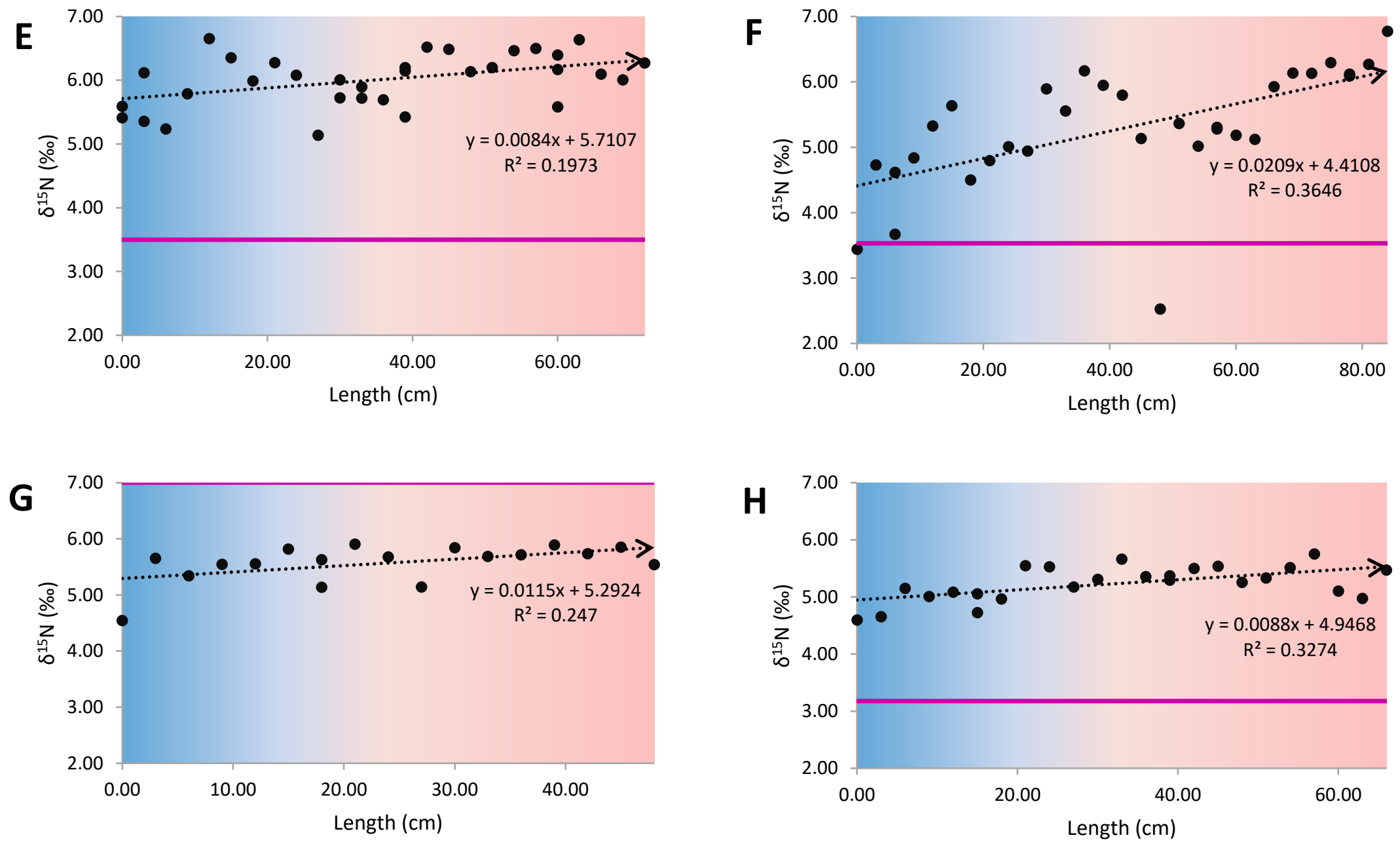

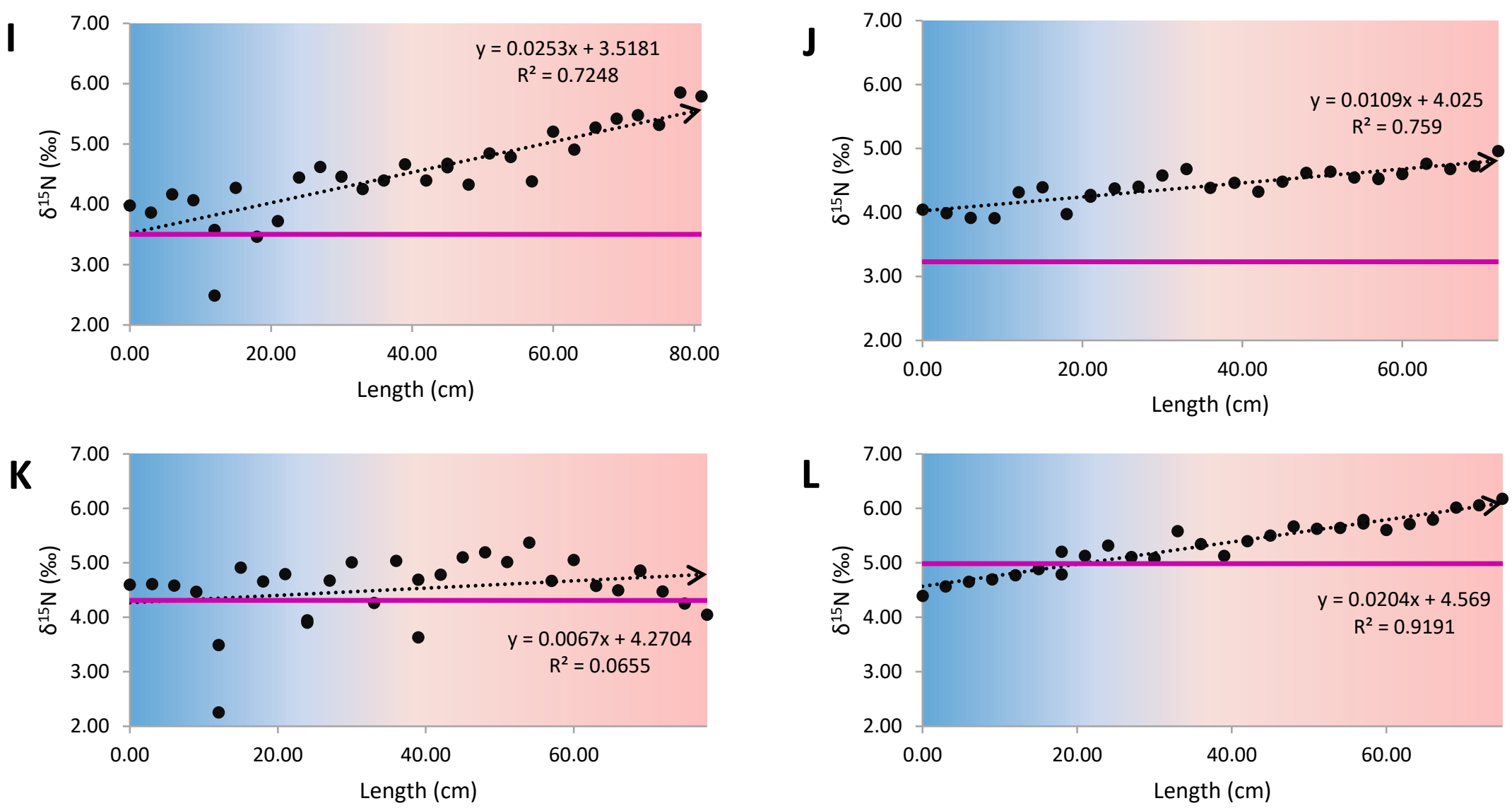

Figure 16. Linear relationship between antler length and $\delta^{15} \mathrm{~N}$ values for collagen stable isotopes. Linear regression analysis indicates all antlers, except (K) 39150, follow a linear relationship with significant $p$-values. The $p$-values for all significant linear relationships are: $A, p=0.001229 ; B$, $p=4.57 E-10 ; C, p=0.000137 ; D, p=9.59 E-07 ; E, p=0.009617 ; F, p=0.000253 ; G, p=0.035858 ; H, p=0.0028 ; I, p=2.48 E-09 ; J, p=3.37 E-09 ; L$, $p=2.85 E-16$. $K$ has a linear regression $p$-value of 0.164788. Antlers analyzed: $A=39079, B=39090, C=30102, D=39107, E=39108, F=39110, G$ $=39120, H=39132, I=39145, J=39148, K=39149, L=39151$. The colour gradient along the graph represents temporal change that occurs during antler growth, blue representing the winter and red the summer. Purple line represents the average bone isotope value. 


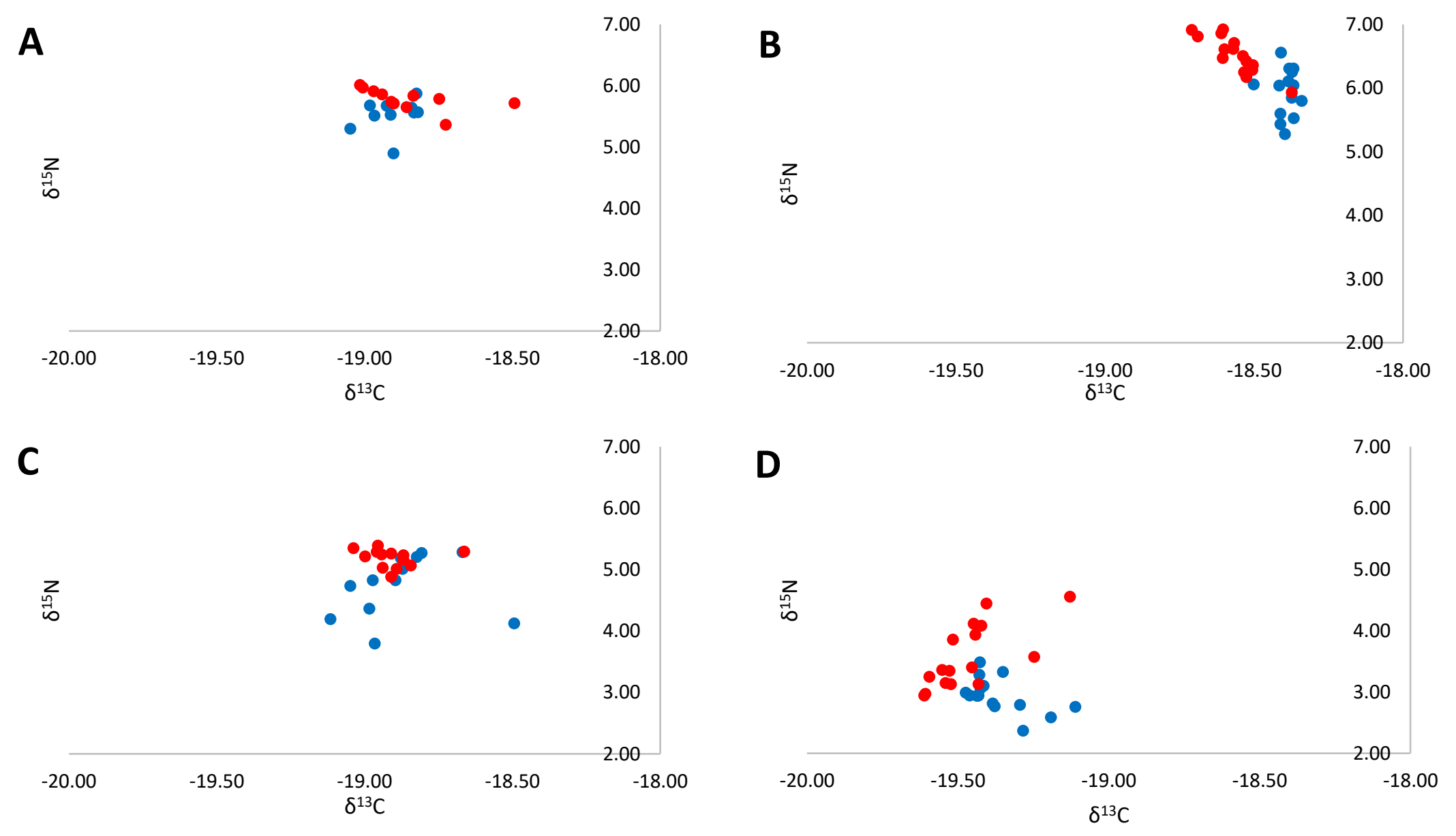



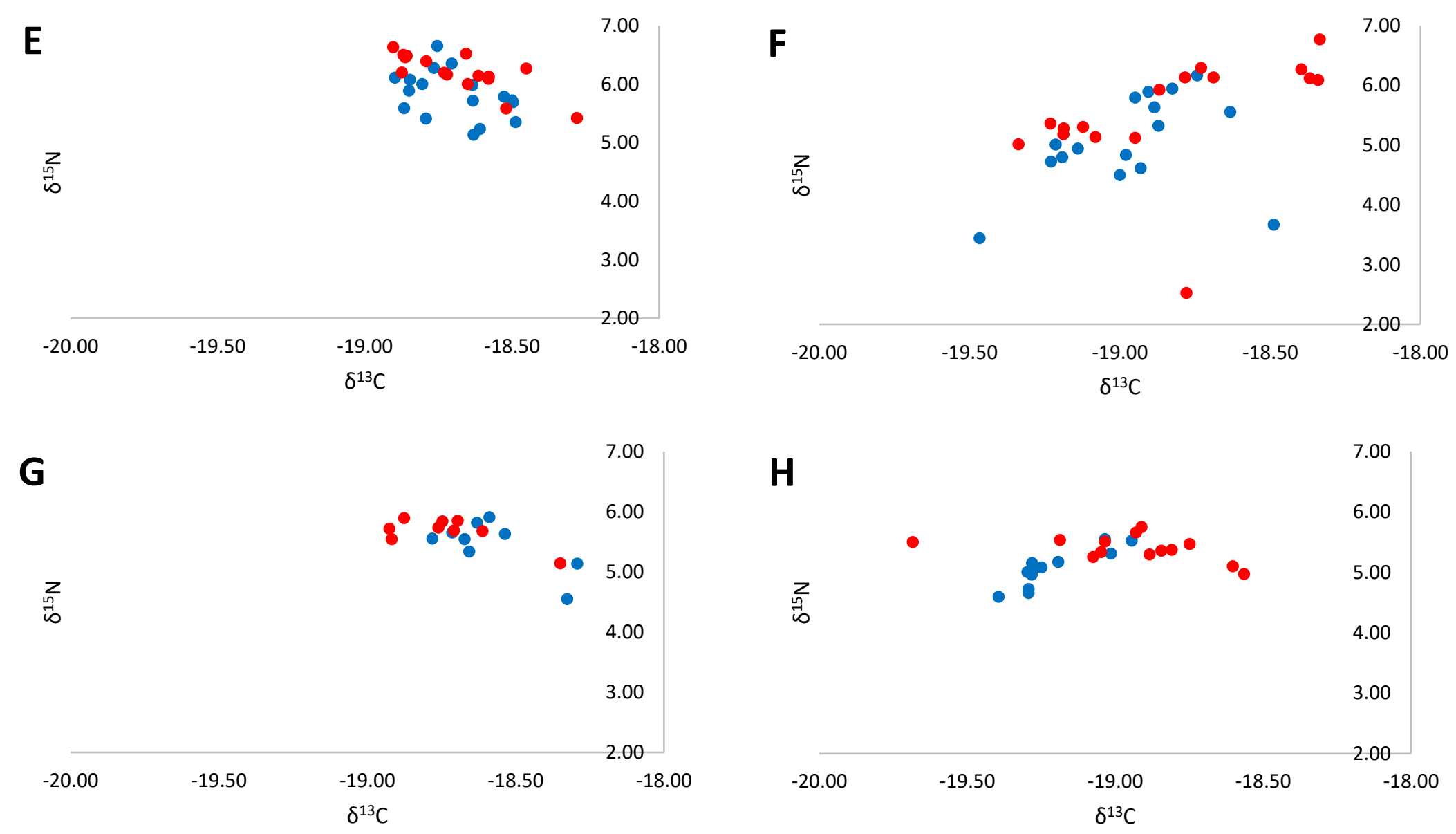

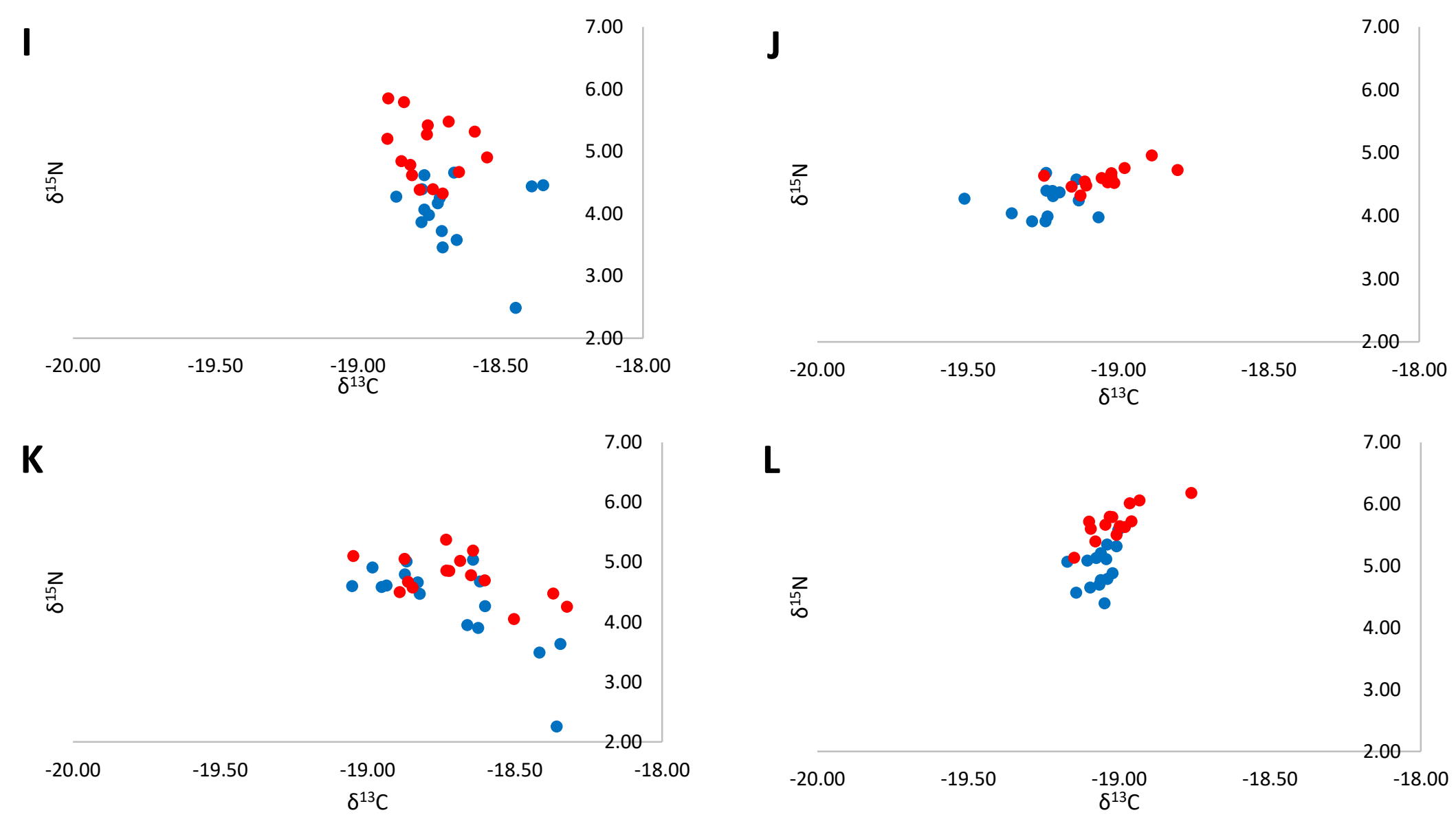

Figure 17. $\delta^{13} \mathrm{C} / \delta^{15} \mathrm{~N}$ values for collagen data for each individual antler. Values are shown in two separate groups, summer (red) values and winter (blue) values. The degree of variation within the antler is quite unique with some individuals showing little change throughout the antler with others containing a high degree of variation. Blue points represent the half of the antler formed between February and April while the red represent April to August. Antlers analyzed: $A=39079, B=39090, C=30102, D=39107, E=39108, F=39110, G=39120, H=39132, I=39145, J$ $=39148, K=39149, L=39151$. 
A

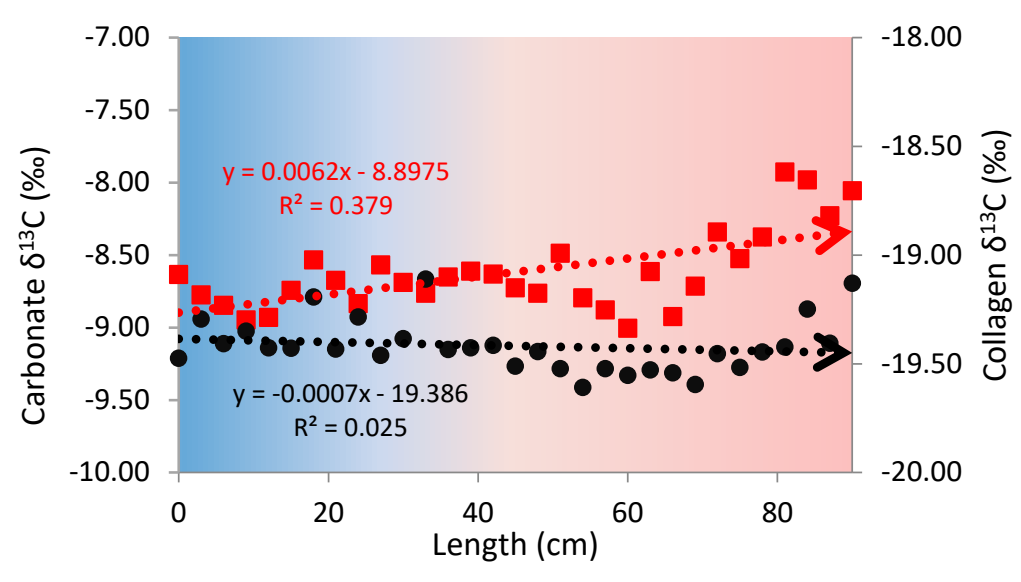

C

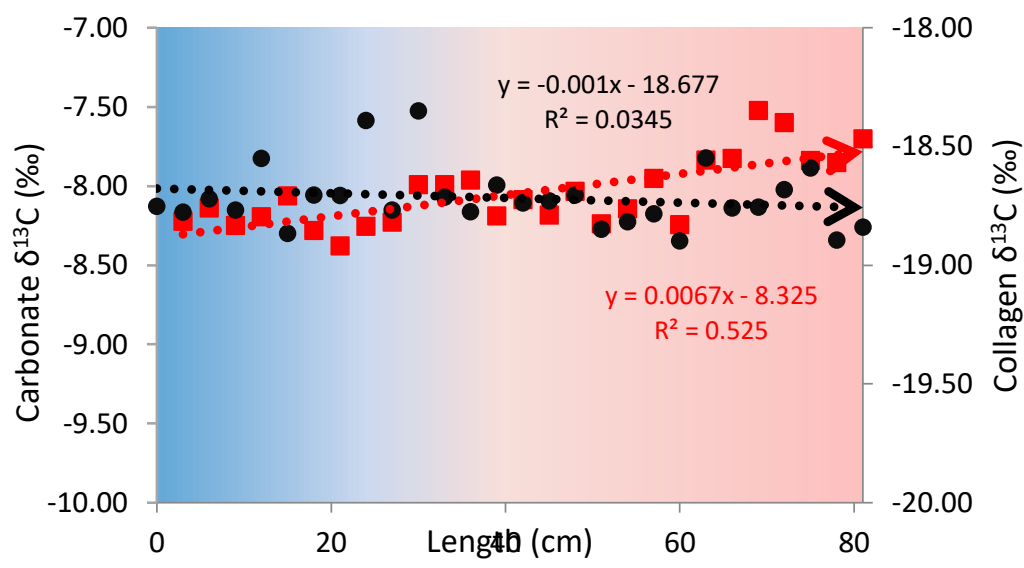

B

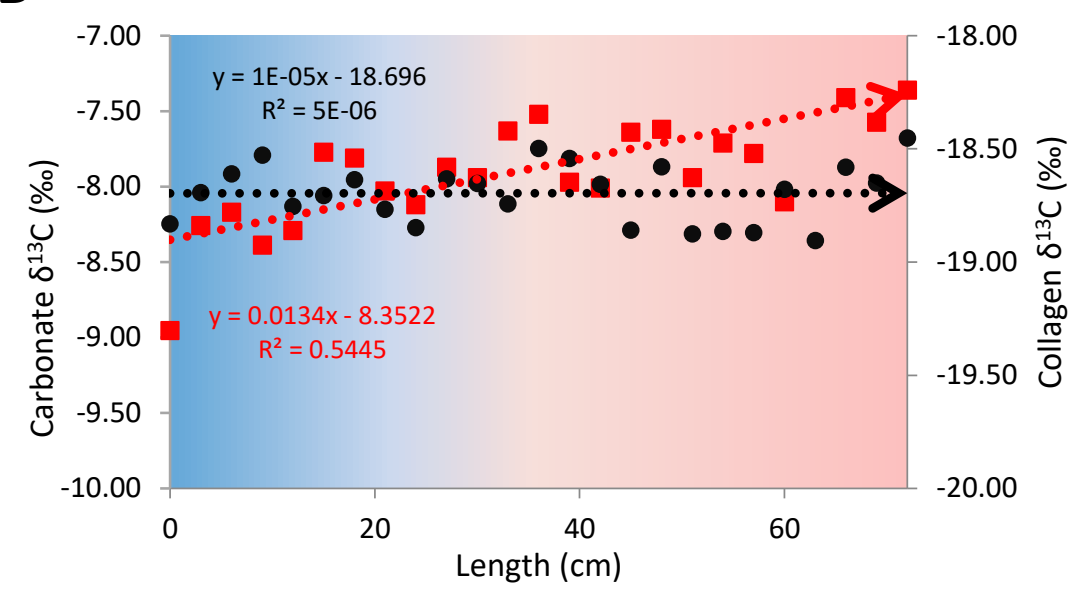

D

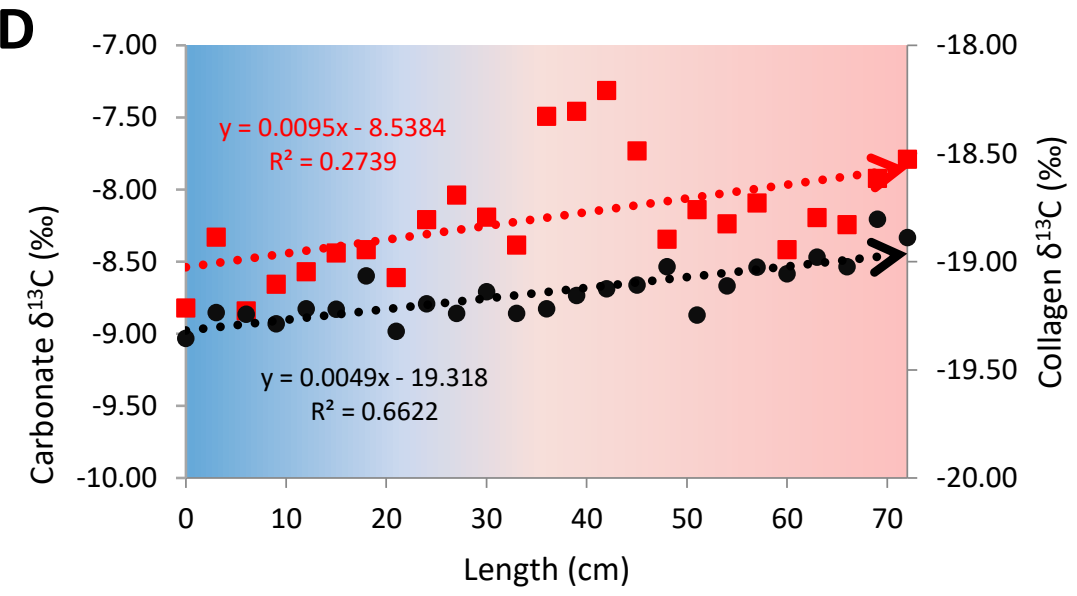




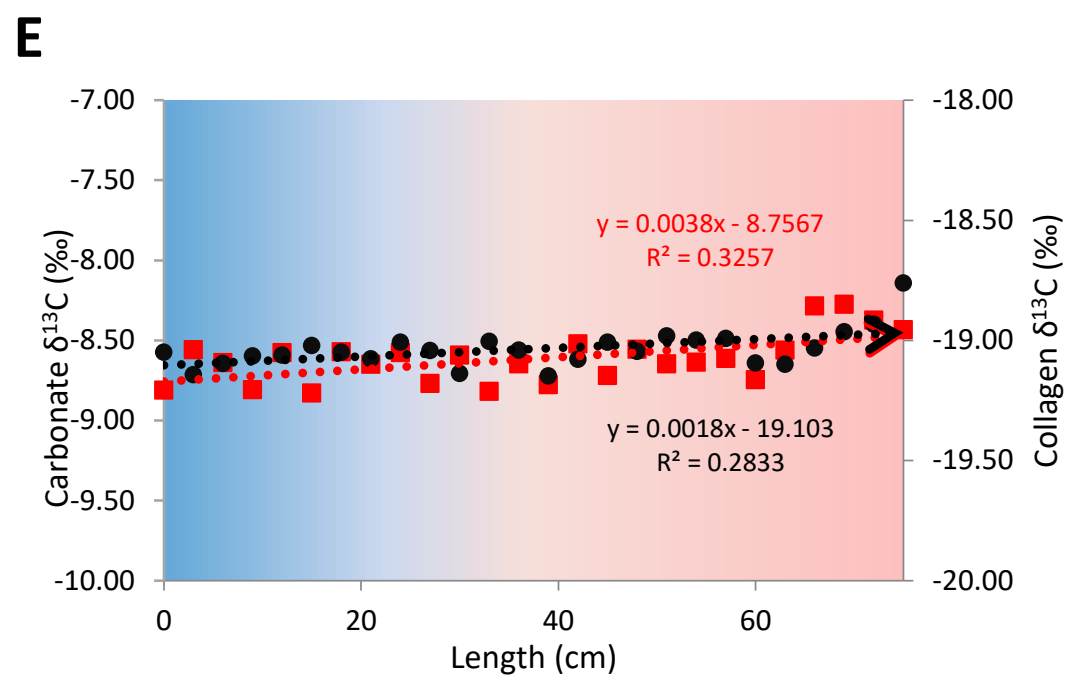

Figure 18. Comparison graphs between the collagen $\delta^{13} \mathrm{C}$ isotopes (indicated in black circles) and carbonate $\delta^{13} \mathrm{C}$ isotopes (indicated in red squares) along the length of the antler. Collagen and carbonate values followed different trends 3 of the 5 samples with similarities only in Antlers D \& E. Antlers analyzed: $A=39107, B=39108, C=39145, D=39148, E=39151$. 
Table 4: Average isotopic values for collagen $\delta^{13} \mathrm{C} \& \delta^{15} \mathrm{~N}$ for mandible (bone) and antler, including $\delta^{13} \mathrm{C} \& \delta^{15} \mathrm{~N}$ values from the antler burr and antler tip. Complete table of all collagen isotope data see Appendix 2: Collagen Stable Isotope Data.

\begin{tabular}{|c|c|c|c|c|c|c|c|c|c|}
\hline \multirow{2}{*}{\multicolumn{2}{|c|}{ Sample }} & \multicolumn{8}{|c|}{ Collagen } \\
\hline & & Antler Tip & Antler Burr & $\begin{array}{l}\text { Antler } \\
\text { Average }\end{array}$ & Bone & Antler Tip & Antler Burr & $\begin{array}{l}\text { Antler } \\
\text { Average }\end{array}$ & Bone \\
\hline & & \multicolumn{4}{|c|}{ Carbon $\left(\delta^{13} \mathrm{C} \%\right.$ o) } & \multicolumn{4}{|c|}{ Nitrogen $\left(\delta^{15} \mathrm{~N} \%\right.$ o) } \\
\hline A & 39079 & -18.86 & -18.90 & -18.88 & -18.52 & 5.65 & 4.90 & 5.66 & 3.30 \\
\hline B & 39090 & -18.71 & -18.40 & -18.48 & -18.82 & 6.91 & 5.28 & 6.24 & 4.27 \\
\hline C & 39102 & -18.66 & -19.04 & -18.89 & -19.21 & 5.29 & 3.99 & 4.97 & 2.29 \\
\hline D & 39107 & -19.13 & -19.47 & -19.42 & -19.28 & 4.55 & 2.99 & 3.25 & 2.67 \\
\hline E & 39108 & -18.45 & -18.83 & -18.69 & -19.50 & 6.27 & 5.50 & 6.00 & 5.13 \\
\hline $\mathbf{F}$ & 39110 & -18.33 & -19.47 & -18.90 & -18.96 & 6.77 & 3.44 & 5.30 & 3.53 \\
\hline G & 39120 & -18.92 & -18.33 & -18.66 & -18.99 & 5.54 & 4.54 & 5.56 & 7.00 \\
\hline H & 39132 & -18.75 & -19.39 & -19.07 & -19.54 & 5.47 & 4.60 & 5.23 & 3.18 \\
\hline I & 39145 & -18.84 & -18.75 & -18.71 & -18.71 & 5.79 & 3.98 & 4.52 & 3.50 \\
\hline J & 39148 & -18.89 & -19.35 & -19.14 & -19.07 & 4.96 & 4.04 & 4.42 & 3.23 \\
\hline K & 39149 & -18.50 & -19.05 & -18.71 & -19.52 & 4.05 & 4.60 & 4.53 & 4.31 \\
\hline $\mathbf{L}$ & 39151 & -18.76 & -19.05 & -19.04 & -18.79 & 6.18 & 4.40 & 5.33 & 4.99 \\
\hline
\end{tabular}




\subsection{Discussion}

The objective of this study was to determine whether Rangifer tarandus (caribou) antlers demonstrate a different isotopic signal in comparison to other hard tissues such as bone and teeth using stable isotopes of oxygen, carbon, and nitrogen. It also aimed to determine whether isotope values varied along the length of the antler growth axis.

\subsection{Antler Trends}

The following discussion of antler trends is presented in the same order as the results. It was predicted that isotopic variation would occur along the growth axis of the antler. Predictions for the cause of this variation were seasonal migration and physiological fractionation.

\subsubsection{Carbonate - Carbon isotopes}

Fifteen specimens were selected for analysis. However, after initial complications with oxygen isotope repeatability, remaining carbonate samples were set aside until a solution could be found to produce reliable oxygen values. Therefore, only five of the 15 were analyzed for carbonate carbon. All specimens showed significantly increasing $\delta^{13} \mathrm{C}$ values of $\sim 1 \%$ along the length of the antler (Fig. 10). Increasing $\delta^{13} \mathrm{C}$ values during antler growth are likely a result of dietary changes during the spring migration (Fig. 3). The spring migration of the Qamanirjuaq population occurs during the first snow melt when the antlers have begun to form (February to March). The antlers continue to grow 
as the population moves through the entirety of the spring migration, from northern Saskatchewan and Manitoba to North Henik Lake in central Nunavut (Miller F.L., 1973).
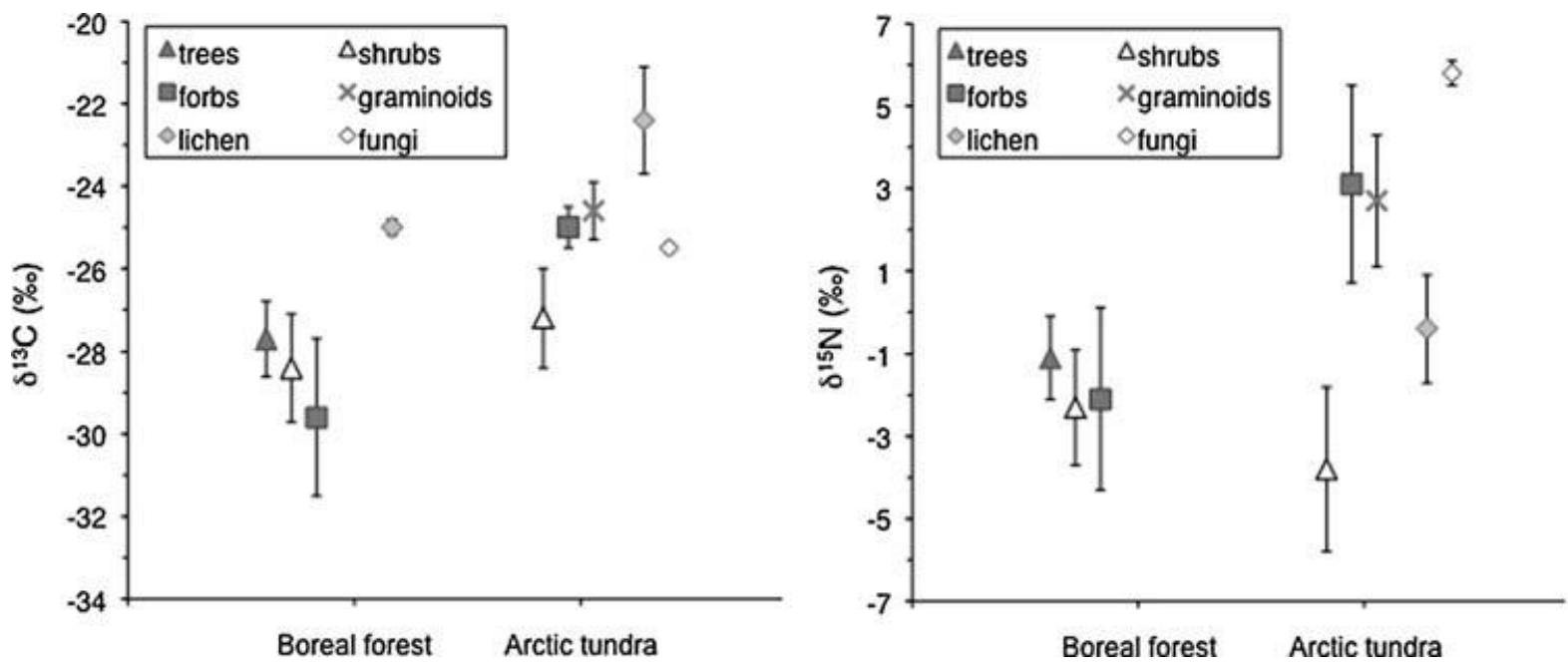

Figure 19. From paper Drucker et al. (2012) a review of the plant isotopes within the boreal forest and Arctic tundra from the following papers Brooks et al. 1997; Milligan, 2008; Griffith et al. 2002; McLeman, 2006; and Barrett, 1994.

The caribou tend to winter in the boreal forest of northern Saskatchewan and Manitoba, where they have access to various food sources, including lichen, a few shrubs, and sedges - primarily Carex aquatilis and Equisetum fluviatile (Table 1; Fig. 4) (Parker, 1973; Baldwin, 1953). During the spring, the caribou begin to migrate northward toward their calving ground near North Henik Lake (Fig. 3), an area characterized by tundra. Various plants and lichens have been shown to increase by 3$5 \%$ in $\delta^{13} \mathrm{C}$ between the boreal forest and tundra (Brooks et al. 1997; Milligan, 2008; Griffith et al. 2002; McLeman, 2006; Barrett, 1994), potentially accounting for the increases in $\delta^{13} \mathrm{C}$ within antlers. Previous studies suggest that caribou show a shift in $\delta^{13} \mathrm{C}$ due to greater consumption of lichen during the winter season (Drucker et al. 2010, 2012). However, lichen is consumed continuously throughout the year and is a staple of 
the Qamanirjuaq caribou diet (Fig. 8), suggesting that a dietary shift away from lichens in the spring may not be a contributor to $\delta^{13} \mathrm{C}$ along antlers.

Dietary shifts are, however, apparent from rumen samples (Table 1). The winter collection period (for 1967) found a higher percentage of occurrence for flora species of the genus Equisetum, and a higher occurrence for select species within the conifer and woody angiosperm groups (i.e. Larix laricina, Andromeda polifolia, Kalmia polifolia, Pinus banksiana and Vaccinium myrtilloides) in the rumen content of the Qamanirjuaq caribou. In comparison, the summer collection period had much higher Betula spp., Pleurozium schreberi, Dicranum spp., Ptilidium ciliare. Kristensen et al. (2011) found that, despite a lack of photosynthetic difference between Arctic plant groups, plants with higher drought tolerance - higher water-use efficiency - have a higher $\delta^{13} \mathrm{C}$ value. In general, there is a $1 \%$ o enriched in ${ }^{13} \mathrm{C}$ in more drought-tolerant plants compared to other graminoids at a similar latitude (Kristensen et al. 2011, Marshall et al. 2007). Higher drought-tolerant plants (e.g. Pleurozium schreberi) are commonly found in the Arctic tundra (Teeri, 1973; Ellis, 2020) and may have a large impact on the shift in $\delta^{13} \mathrm{C}$ found throughout the length of the antler.

As part of future work in this area, I plan to test whether the $\delta^{13} \mathrm{C}$ values in plants collected from rumen samples, during the CWS study, align with the shifts in $\delta^{13} \mathrm{C}$ found throughout the antler length. I hope to test the isotopic composition of several Arctic plant species, including lichens (i.e. Cladina spp., Cladonia spp. and Stereocaulon spp.), Bryophyta (i.e. Pleurozium schreberi and Ptilidium ciliare), Angiosperms (i.e. Kalmia 
polifolia, Andromeda polifolia, Vaccinium myrtilloides, and Betula spp.), and Equisetum spp.

\subsubsection{Carbonate - Oxygen isotopes}

Oxygen isotope analysis from carbonates of antler tissue proved to be challenging because the second pre-treatment step (1 M acetic acid treatment for 24 hours) dissolved all the antler material. The acetic acid pre-treatment is designed to remove exogenous carbonates - carbonates formed through post-mortem weathering however, the antlers studied were collected immediately after death, thus the acetic acid pre-treatment was deemed inconsequential. After I forwent the acid treatment, oxygen isotope analysis of the carbonates did not produce repeatable results (Fig. 12). There are several potential reasons for these complications.

Firstly, the pre-treatment used for this study was one designed for bone and tooth enamel and, while antler has a similar make up of protein and calcium hydroxylapatite, the crystal structure of antlers is different. Chen et al. (2009) studied the structure and mechanical properties of bone and antler in North American Elk (Cervus elaphus canadensis). Caribou, elk, and moose have the fastest growing antlers of the 40 cervid species that grow antlers. Chen et al. (2009) found that antlers have a platelet crystalized structure that range from $20-70 \mathrm{~nm}$ in length and have a thickness of $4 \mathrm{~nm}$. Bone has a similar structure and the crystals vary in size from $25-50 \mathrm{~nm}$ with a thickness of $3 \mathrm{~nm}$. The different crystal structure of antlers provides a higher surface area for the transportation of nutrients within the antlers vascular system (Chen et al. 
2009). The high surface area could also have caused a dissolution of the antler material during the $1 \mathrm{M}$ acetic acid treatment, resulting in the antler material being lost.

A second plausible explanation is a post-sampling re-crystallization of antler material. Re-crystallization can result in changes in the $\delta^{18} \mathrm{O}$ values of carbonates. Koch et al. (1997) noted that acids can promote the recrystallization of hydroxylapatite into brushite during chemical pre-treatment. This recrystallization can be particularly potent with acids such as $1 \mathrm{M}$ acetic acid; a step - as previously mentioned - which was removed during pre-treatment. While Koch et al. (1997) did not determine any recrystallization when using $2 \% \mathrm{NaOCl}$, they did not conduct the experiment on antler crystals. The submersion of the antler crystals in $2 \% \mathrm{NaOCl}$ for 24 hours, in conjunction with the naturally high surface area of antler crystals, could have potentially caused the disproportionate recrystallizing of hydroxylapatite into brushite or other minerals. This offset would have caused a change in the $\delta^{18} \mathrm{O}$ samples but would not impact the $\delta^{13} \mathrm{C}$ values because brushite does not contain carbon. Koch et al. (1997)'s study also provides a second possibility to explain the poor repeatability of the carbonate oxygen isotopes in Rangifer tarandus antlers. Structural carbonate within biological hydroxylapatite is chemically bound at phosphate and hydroxyl lattice sites. The variation between chemical bond strengths could lead to differences in atmospheric exchange rates at these two sites. If, during pre-treatment, the high surface area of antler crystals allowed partial dissolution of carbonate at these sites, the disproportional release of carbonate from the phosphate and hydroxyl lattice sites could have altered the apparent $\delta^{18} \mathrm{O}$ values of samples. It is unlikely that the $2 \% \mathrm{NaOCl}$ solution would 
cause these complications presented by Koch et al. (1997), however, with relatively little understanding of antler isotope analysis I believe it is worth further investigation in the future.

Finally, the sample washing procedure, which is conducted to remove all traces of pre-treatment chemicals from the sample, could have led to the poor repeatability of stable oxygen isotopes. The high surface area of antler crystal structures may have led to the rehydration of antler crystals during the wash with deionized water. Oxygen isotopes from the water molecules may have bonded or replaced the oxygen within the carbonate. Figure 12 shows the comparison of repeat samples with most varying by $5 \%$, possibly indicating a contamination from a single source (i.e. the deionized water). The rehydration may have transpired when samples were heated in an oven to dry overnight. However, to test this assumption, samples were placed in a freeze drier overnight. Oxygen isotope values from duplicates of the same sample still showed poor repeatability. Rehydration in antlers has been shown to occur and improve antler elasticity and fracture toughness in comparison to dry antler (Chen et al. 2009). A high rehydration potential may be important for antler function but may have caused the isotope sampling issues within Rangifer tarandus antlers.

For future analysis, experimenting with different pre-treatment protocols will be critical. In combination with Fourier-transformed infrared spectroscopy (FTIR), which provides information on crystal structure, it will provide a means of understanding variability in carbonate oxygen isotopes. In addition to FTIR and pre-treatment experiments, use of phosphate oxygen isotope values could present an alternative that 
may suffer less from oxygen exchange with the atmosphere and water due to greater bond strength.

\subsubsection{Collagen - Carbon Isotopes}

There is a debate among scientists about whether carbonate or collagen stable carbon isotopes offer a better isotopic representation of diet, with many studies advocating for the use of both (Clementz et al. 2009; Froehle et al. 2010; Codron et al. 2018). The utility of sampling the same tissue for carbon isotopes from both tissues relates to the difference in carbon sourcing. Carbonate carbon incorporates carbon from all nutrient consumption, thus reflecting the average diet, whereas collagen is incorporating carbon preferentially from dietary protein (Ambrose \& Norr, 1993). Studying both tissues might therefore provide a more holistic understanding of diet. There is, however, much more ecological research utilizing collagen carbon isotopes, as finding the source of dietary protein can often be easier than observing the entire bulk diet. Herein, I was able to utilize both for a subset of specimens.

I expected that migration between the boreal forest and tundra ecozones during the spring migration would result in an increase in $\delta^{13} \mathrm{C}$ values for antler collagen, as with the carbonates. Unlike the antler carbonates, however, collagen $\delta^{13} \mathrm{C}$ values from 12 sampled antlers did not show increases (Fig. 15). Only six of 12 showed a statistically significant change in $\delta^{13} \mathrm{C}$ (Fig. 15). In particular, the five antlers analyzed for both carbonate and collagen stable carbon isotopes did not show consistent change (Fig. 18). Of the five individuals sampled for both carbonate and collagen $\delta^{13} \mathrm{C}$ values, only two 
showed consistent increases along the length of the antler for both tissues (Fig 18). However, future study will need to increase the carbonate sampling to create a better comparison to collagen values.

Typically, carbonate and collagen carbon values show a linear relationship, with carbonate $\delta^{13} \mathrm{C}$ showing a 9\%o enrichment (Codron et al. 2018; Ambrose \& Norr, 1993). Carbonate $\delta^{13} \mathrm{C}$, however, has been found to be significantly less variable than collagen $\delta^{13} \mathrm{C}$, particularly with regards to seasonal dietary changes involving high protein plants (Codron et al. 2012). Nutrients consumed by Rangifer tarandus of the Qamanirjuaq population are entirely derived from plant consumption. Within a plant, $\delta^{13} \mathrm{C}$ can vary among the carbohydrates, lipids, and proteins (Dungait et al. 2008), potentially producing differences between carbon isotopes within collagen and carbonates. If plant protein is enriched in ${ }^{13} \mathrm{C}$, then the caribou consumption of high protein plants during the summer months (Drucker et al. 2001) could result in $\delta^{13} \mathrm{C}$ trend differences between collagen and carbonates.

High protein plant consumption could result in the different trends between collagen and carbonate results. Additionally, individualistic migratory and dietary behaviour might contribute to the variability among collagen findings. During the spring and summer, male caribou migratory patterns are inconsistent, many are scattered throughout the populations range, until they begin to migrate north to Henik Lake for the rut (Fig. 3) (Parker, 1973). Males may move in either small bands or independently (Parker, 1973; Miller F.L., 1973). To minimize potential variation due to differences in migration routes, samples were selected from similar localities, however, this does not 
eliminate all possible effects of the scattered spring migration behavior. The lack of consistent migratory patterns among the males could lead to the consumption of different high protein plants. Caribou have very flexible foraging behaviour and can switch dietary items depending on biomass availability (Barboza, 2018; Van der Wal et al. 2000, Thompson et al. 2015, Denryter et al. 2017). It is possible that the male caribou selected for study had different foraging behaviours. If the high protein plants varied significantly in $\delta^{13} \mathrm{C}$ values the result would cause a high degree of variation within my antler samples.

To address this hypothesis, I suggest two additional stable isotope analyses. Strontium isotope analysis along the antler growth axis could be used to measure different migratory patterns between the male caribou. Strontium isotopes have been, previously, used to measure migration patterns in Rangifer tarandus teeth (Britton et al. 2011) but not antlers. A second stable isotope analysis could be conducted on Arctic plants, studying the difference in protein $\delta^{13} \mathrm{C}$ values. Arctic plants found in rumen contents (Table 1) may provide information as to the variability found within collagen carbon samples.

As mentioned, protein is a limiting nutrient for herbivores like caribou during the winter months (Gerhart et al. 1996), limited protein availability may also cause the variation seen with collagen carbon results (Fig. 15). Like many ruminants, caribou will recycle protein from reserves into urea though protein catabolism, when protein sources are scarce (Drucker et al. 2010; Soveri et al. 1992; \& Westerling, 1970). Recycling of proteins occurs within the foregut and causes a substantial enrichment ${ }^{13} \mathrm{C}$ 
(Parker et al. 2005). If both diet and protein recycling production vary throughout the antler growth season it may result in the observed changes. Furthermore, the rut, which occurs in November, may also lead to nutrient stress and increased protein recycling.

Finally, one other possible cause for the variation observed in collagen carbon $\delta^{13} \mathrm{C}$ values is methane production. Herbivores produce methane through microbial fermentation in the gastrointestinal tract this causes the preferential loss of ${ }^{12} \mathrm{C}$, resulting in higher $\delta^{13} \mathrm{C}$ values within the body and newly synthesized tissue (Codron et al. 2018; Hedges, 2003; Passey et al. 2005). Seasonal changes in methane production could result in the $\delta^{13} \mathrm{C}$ values found within the antler. However, this would affect all synthesized tissue and the results would be present in collagen and carbonate isotopes. Presently, the lack of variation among carbonate values indicates that this is an unlikely explanatory factor, more carbonate results are needed.

\subsubsection{Collagen - Nitrogen Isotopes}

For 11 out of the 12 Rangifer tarandus antlers sampled, there was significant increase in $\delta^{15} \mathrm{~N}$ values of $1-3 \%$ along the growth axis (Table 4). $\delta^{15} \mathrm{~N}$ values are often used to determine the trophic level of a species, with increases of $~ 3 \%$ indicating a shift from one trophic level to another (Minagwa \& Wada, 1984; DeNiro \& Epstein, 1981; Kelly, 2000). The consistent 1-3\% for caribou antlers are therefore nearly the equivalent of an increase in one trophic level (Fig. 6). Though individualistic foraging behaviours may have driven the observed changes in $\delta^{13} \mathrm{C}$ from collagen, this does not appear to be 
the case for $\delta^{15} \mathrm{~N}$ despite my expectations (Fig. 6). This unexpected and consistent increase in $\delta^{15} \mathrm{~N}$ may have three plausible explanations.

The first possibility is that the increasing $\delta^{15} \mathrm{~N}$ values are reflective of increased mushroom consumption during the late summer and early winter (Table 1). Caribou show virtually no mushroom consumption during the months of June, February, and April but significant consumption in September (Fig. 4). Several other studies show that caribou actively seek to consume mushrooms (Launchbaugh \& Urness, 1992; Karaev, 1968; Boertjie, 1981). Fungi (i.e. mushrooms) have a substantially higher $\delta^{15} \mathrm{~N}$ values relative to other Arctic plants (Fig. 19) (Drucker et al. 2012; Barnett, 1994). The dietary preference of mushrooms may therefore create the increase in $\delta^{15} \mathrm{~N}$ along the antler growth axis. Future analysis of isotopic composition of $\delta^{15} \mathrm{~N}$ in Arctic fungi from the same region where the antlers were harvested is, however, necessary.

The second possibility is nutrient stress (Ambrose, 1991; Kelly, 2000; Hobson \& Clark, 1992; Cormie \& Schwarcz, 1996). Enrichment of $\delta^{15} \mathrm{~N}$ values in tissue are shown to be caused by nutrient stress, due to metabolizing of the body's tissue, particularly nitrogen-rich fat, resulting in the recycling of nitrogen in the body (Kelly, 2000). This effect can be particularly strong in select ruminants (including Rangifer tarandus), where water stress result in recycling of urea in the gut as a source of nitrogen for microbial digestion (Ambrose, 1991). The 1966/1967 winter was associated with high snow accumulation and lower than average temperatures (Dauphine, 1973), which may have resulted in higher than average nutrient stress. Deep snow can inhibit the caribou's access to subnivean plant materials causing an increase in nutrient stress (Schaeffer \& 
Mahoney, 2001; Espmark, 1964; Barrette \& Vandal, 1986, 1990). Furthermore, the rut occurs in October and males are usually starved prior to and during the rut (Drucker et al. 2010), further contributing to nutrient stress and $\delta^{15} \mathrm{~N}$ increases in the antler collagen.

Finally, consistent $\delta^{15} \mathrm{~N}$ increases in male Qamanirjuaq caribou antlers may be caused by nutrient and bone resorption during antler growth. Baksi and Newbrey (1989) found that bone ash and calcium percentage were significantly lower in July relative to January in caribou ribs while osteoid volume (collagen) was significantly higher. Antler growth is highly taxing and often nutrients will be repurposed from with in the body (often from the rib cage) to aid with heavily nutrient dependent growth of antlers. The redistributing of nutrients may have an isotopic effect that has not been observed, it could be a potential cause of the persistent increase in $\delta^{15} \mathrm{~N}$ values.

\subsection{Tissue Comparison}

Bone and teeth have been thoroughly studied, their patterns of isotope incorporation are well known and commonly used for ecological studies (e.g. Passey \& Cerling, 2002; Fricke \& O'Niel, 1996; Fricke et al. 1998; Eriksen et al. 1990). Herein, I show that antlers are unique in that their patterns of isotopic variation are different from teeth and bone. I hypothesized that isotopic variation would occur between the three tissues due to differences in timing of tissue development and times over which the different tissues

exchange isotopes with the available "pool" in the body (Hedges, 2007; Drucker et al. 2010; Gannes et al. 1997). Antler, bone, and tooth tissues form during different times of 
the year and incorporate isotopes from the diet over different temporal scales. Antler forms from February to end of August, a roughly 200-day growth period (Miller F.L., 1973; Schaefer \& Mahoney, 2001). In contrast, formation (amelogenesis) and mineralization of the third lower molar $\left(\mathrm{M}_{3}\right)$ takes approximately 6 months. Mineralization of the $\mathrm{M}_{3}$ in Cervus elaphus (Elk) begins at roughly 13 months of age and continues until approximately 18 months of age, thus forming from the mid to late summer through winter of the second year of life (Miller F.L., 1973; Fricke et al. 1998; Kohn, 2004; Brown \& Chapman, 1991). We can reasonably assume a similar developmental trajectory for caribou lower third molars. In contrast, bone continuously remodels and does not represent a single snapshot in time (Hedges et al. 2007). For example, Matsubayashi \& Tayasu (2019) tested stable isotope turnover in bone collagen for sika deer and found that isotopic composition remained unchanged during the first 2.5 years of rapid bone growth and reflected the average diet.

I also expected that any difference in stable isotope values among the three tissues would be related to the differences in the temporal scale over which isotopes are incorporated from the diet into the tissue rather than differences in developmental pathways. The developmental pathway is similar for all three tissues used herein. The mineral components of antler, bone, and tooth enamel are all comprised of hydroxylapatite (Chen et al. 2009; Chritz et al. 2009; Koch, 1998; Kohn \& Cerling, 2002), which is sourced from the bicarbonate pool in the body fluid that derives its isotopic signature from all dietary components - protein, carbohydrates and lipids (Codron et al. 2018). Similarity in the isotopic source for the three tissues suggests that timing of 
development and duration of exchange with the body fluid should have a greater impact on their comparative isotopic signatures.

Bone and antler incorporate protein in the form of collagen (type 1) into the mineral matrix (Stevens \& O'Connell, 2016). Both antler and bone are supplied the collagen proteins through the blood stream. Antlers have highly vascularized tissue with blood being supplied through the velvet membrane and the pedicle. Bone growth and remodelling is conducted by osteoblasts and osteoclasts; the bone forming cells (osteoblasts) are supplied material through extracellular fluid, primarily comprised of blood and plasma (Chen et al. 2009; Eriksen, 2010; Eriksen et al. 1990). It is therefore reasonable to presume that both tissues have a similar isotopic source.

I found that the $\delta^{13} \mathrm{C}$ values of carbonates from bone are approximately $1 \%$ lower than antler tissue for all five individual caribou (Fig. 13), a likely result of bone remodeling, which leads to time averaging of isotopic signals from the diet over several years (Matsubayashi \& Tayasu, 2019; Hedges et al. 2007). The Qamanirjuaq caribou show distinct seasonal shifts in diet between the summer and winter months (Miller F.L., 1973). Antler formation, occurring from early February to late August, largely reflects diet during the summer months, which is overall higher in $\delta^{13} \mathrm{C}$ (Fig. 10) (Drucker et al 2010; 2012). In contrast, the time averaging of bone isotopic values creates a $\delta^{13} \mathrm{C}$ signal that reflects both the summer and winter diets, which show overall lower $\delta^{13} \mathrm{C}$ values (Fig. 13).

During the winter months, both antler and tooth isotopic values are at their lowest (Fig. 13; dark blue area of the plot). Antler $\delta^{13} \mathrm{C}$ values then increase along the 
axis of the antler growth (from pedicle to tip), representing the late winter to late summer (Fig. 13). The values for tooth and antler peak during the late summer months, the period when antler formation is completed (the tip of the antler) and tooth mineralization is beginning (the crown; Fig. 13). Contrary to antlers, tooth enamel $\delta^{13} \mathrm{C}$ values decreased along from the crown to root (Fig. 13), representing their period of formation, late summer to mid-winter. Combining antler and tooth stable isotopes may therefore provide a record of nearly year-round dietary data for caribou, which would be unprecedented for cervids, but this requires further testing. 


\subsection{Conclusion}

The Qamanirjuaq population of Rangifer tarandus groenlandicus (Barren-Ground Caribou) are of both ecologic and socio-economic importance to the North.

Unfortunately, given pronounced Arctic climate change, the population is in decline. This study determined that male Rangifer tarandus antlers of the Qamanirjuaq population can provide a unique isotopic signature in comparison to other hard tissues such as bone and teeth. Antlers isotope signals may reflected the isotopic composition of food and water consumed during the spring and summer of a single year and could provide a high-resolution record of ecological conditions. In comparison to other hard tissues such as bone and teeth, antlers had different stable isotope profiles of carbon and nitrogen. Variation in the rate and timing of tissue development created the different stable isotope profiles for each tissue observed. Fifteen males were selected, from the Canadian Museum of Nature collection, based on geographic location, sex, maturity, and collection date. Samples were then processed using alterations to the standard procedures for both collagen and carbonate extraction. The carbon and nitrogen isotope results for collagen along the antlers showed a significant pattern of variation, demonstrating the potential of such data as ecological indicators during the antler growth period. Similarly, carbon and oxygen isotope results for carbonates showed patterns of variation for carbon, potentially providing another signal of ecological variation during antler growth. This study helps provide a tool for better understanding the ecology of caribou populations within Canada. Moving forward, additional stable isotopes should be measured to verify findings and to incorporate new 
potential avenues for discovery. Pleistocene antlers will be sampled to help determine the adaptability of climate change in Rangifer tarandus.

\subsection{Future Implications}

This study lays the foundation for future research into the use of antlers as ecological indicators. My study has shown that antlers vary isotopically throughout the length of the antler in both $\delta^{13} \mathrm{C}$ and $\delta^{15} \mathrm{~N}$. The variation along the length of the antler is most likely an indication of dietary changes between ecozones and nutritional stress. The implications of these findings provide us with the opportunity to use antlers as a tool to determine changes in regards to caribou ecology. Antlers are particularly beneficial as they provide a high-resolution image of the spring and summer period, a period of migration and growth for caribou. However, further research is required before more definitive conclusions can be made. Stable isotope analysis of Arctic plants will help support the conclusions drawn in the discussion section. To determine the isotopic variation within diet, the plants found in the rumen contents of caribou collected (see Table 1 and Fig. 4) will need to be analyzed. In addition, other isotopes need to be analyzed to create a greater understanding of the ecology an antler can represent. The completion of oxygen isotope analysis may potentially show temperature changes throughout the antler growth season and strontium isotopes may provide information about migratory patterns during the spring migration.

The implications of this research can also be applied to Pleistocene caribou. Pleistocene caribou survived dramatic climate change similar in many respects to the 
climate change experienced by modern caribou. By researching the effect of climate change on Pleistocene caribou through antler fossils, we may be able to generate a better understanding of the impact modern climate change is having on the Qamanirjuaq and other caribou populations. Within the fossil record, antlers are more abundant as they grow and are shed annually, therefore representing an ideal fossil to study Pleistocene caribou ecology.

The benefits of antler isotope research are just beginning to be understood and this study helps further the research. Antlers yearly growth and shedding provide a humane means of studying dietary and potentially ecological changes around a caribou population. 


\subsection{References}

1. Adams J.M. et al. "Increases in terrestrial carbon storage from the Last Glacial Maximum to the present." Nature 348.6303 (1990): 711.

2. Albon S.D. et al. "The role of parasites in the dynamics of a reindeer population." Proceedings of the Royal Society of London B: Biological Sciences 269.1500 (2002): 1625-1632.

3. Albon S.D., Irvine R.J., Halvorsen O., Langvatn R., Loe L.E., Ropstad E. et al. "Contrasting effects of summer and winter warming on body mass explain population dynamics in food-limited Arctic herbivore." Glob. Change Biol. 23 (2017) 1374-1389.

4. Álvarez-Lao D.J., and García N. "Geographical distribution of Pleistocene cold-adapted large mammal faunas in the Iberian Peninsula." Quaternary International 233.2 (2011): 159-170.

5. Ambrose, S.H. "Effects of diet, climate and physiology on nitrogen isotope abundances in terrestrial foodwebs." Journal of archaeological science 18.3 (1991): 293-317.

6. Ambrose S.H. "Isotopic analysis of paleodiets: methodological and interpretive considerations." In investigations of ancient human tissue. Edited by M.K. Sandord. Gordon and Breach, Langhorne, $\mathrm{Pa}$ (1993): 59-130.

7. Ambrose S. H., and Norr L. "Carbon isotopic evidence for routing of dietary protein to bone collagen, and whole diet to bone apatite carbonate: purified diet growth experiments." Molecular archaeology of prehistoric human bone. Springer, Berlin Heidelberg New York (1993): 1-37.

8. Amrollahi P., Shah B., Seifi A., and Tayebi L. "Recent Advancements in Regenerative Dentistry: A Review." Materials Science and Engineering C 69 (2016): 1383-1390.

9. Anderson T. A., and C. J. Johnson. "Distribution of barren-ground caribou during winter in response to fire." Ecosphere 5.10 (2014): 1-17.

10. Anisimov O., Vaughan D., Callaghan T., Furgal C., Marchant H., Prowse T., Vilhjálmsson H., and Walsh J. "Polar regions (Arctic and Antarctic)." Climate Change 2007: Impacts, Adaptation and Vulnerability. Contribution of Working Group II to the Fourth Assessment Report of the Intergovernmental Panel on Climate Change, Cambridge University Press (2007): 653-685.

11. Banks W. J. "The ossification process of the developing antler in the white-tailed deer (Odocoileus virginianus)." Calcified tissue research 14.1 (1974): 257-274.

12. Baksi S.N., and Newbrey J.W. "Plasma calcemic hormones in mature female reindeer, Rangifer tarandus." General and comparative endocrinology 69.2 (1987): 262-266.

13. Baksi, S.N., and Newbrey J.W. "Bone metabolism during antler growth in female reindeer." Calcified tissue international 45.5 (1989): 314-317.

14. Baldwin W.K.W. "Botanical Investigations in Reindeer-Nucltin Lakes area, Manitoba." Nat. Mus. Can. Bull. 128 (1953): 110-142.

15. Ballantyne A.P., Rybczynski N., Baker P.A., Harington C.R., and White D. "Pliocene Arctic temperature constraints from the growth rings and isotopic composition of fossil larch." Palaeogeography, Palaeoclimatology, Palaeoecology 242 (2006): 188-200.

16. Ballesteros, M. et al. "The effect of warble flies on reindeer fitness: a parasite removal experiment." Journal of Zoology 287.1 (2012): 34-40.

17. Barber Q.E. et al. "Potential impacts of climate change on the habitat of boreal woodland caribou." Ecosphere 9.10 (2018).

18. Barboza P.S., Van Someren L.L., Gustine D.D., and Bert-Harte M.S. "The nitrogen window for arctic herbivores: plant phenology and protein gain of migratory caribou (Rangifer tarandus)." Ecosphere 9:1 (2018): e02073.10.1002/ecs2.2073

19. Barnett B.A. "Carbon and nitrogen ratios of caribou tissues, vascular plants and lichens from Northern Alaska." M.Sc. Thesis, University of Alaska, Fairbanks (1994). 
20. Barrette C., and Vandal D. "Social rank, dominance, antler size, and access to food in snow-bound wild woodland caribou." Behaviour 97.1 (1986): 118-145.

21. Barrette C., and Vandal D. "Sparring and access to food in female caribou in the winter." Animal behaviour (1990).

22. Barnosky, A.D. "The late Pleistocene event as a paradigm for widespread mammal extinction." Mass extinctions: processes and evidence (1989): 235-54.

23. Barnosky, A.D. et al. "Assessing the causes of Late Pleistocene extinctions on the continents." Science 306.5693 (2004): 70-75.

24. Barnosky A.D. et al. "Approaching a state shift in Earth's biosphere." Nature 486 (2012): 52-58.

25. Bergerud, Arthur T. "Decline of caribou in North America following settlement." The Journal of Wildlife Management (1974): 757-770.

26. Beverly and Qamanirjuaq Caribou Management Board, 2020. "Caribou Resources." Government of Canada, Government of Nunavut, Government of Manitoba, Government of Northwest Territories, Government of Saskatchewan, 25 July $2020<$ https://arcticcaribou.com/resources/\#maps>

27. Bleam W. "Chapter 7 - Natural Organic Matter." Soil and Environmental Chemistry (Second Edition) (2017): 333-384.

28. Blinnikov M.S. et al. "Pleistocene graminoid-dominated ecosystems in the Arctic." Quaternary Science Reviews 30.21-22 (2011): 2906-2929.

29. Bocherens H. et al. "Isotopic biogeochemistry $\left({ }^{13} \mathrm{C},{ }^{18} \mathrm{O}\right)$ of mammalian enamel from African Pleistocene hominid sites." Palaios (1996): 306-318.

30. Boertjie R.D. "Nutritional ecology of the Denali caribou herd." Unpublished master's thesis, University of Alaska, Fairbanks (1981).

31. Boutton T.W. "Stable carbon isotope ratios of natural materials: II. Atmospheric, terrestrial, marine, and freshwater environments." Carbon isotope techniques 1 (1991): 173.

32. Britton K., Grimes V., Niven L., Steele T.E., McPherron S., Soressi M., Kelly T.E., Jaubert J., Hublin J.J., and Richards M.P. "Strontium isotope evidence for migration in late Pleistocene Rangifer: Implications for Neanderthal hunting strategies at the Middle Palaeolithic site of Jonzac, France." Journal of Human Evolution 61.2 (2011): 176-185.

33. Bronckers, A.L.J.J. "Ion transport by ameloblasts during amelogenesis." Journal of dental research 96.3 (2017): 243-253.

34. Brooks J.R., Flanagan L.B., Buchmann N., and Ehleringer J.R. "Carbon isotope composition of boreal plants: Functional grouping of life forms." Oecologia 110 (1997): 120-131.

35. Brown W.A.B., and Chapman N.G. "Age assessment of red deer (Cervus elaphus): from a scoring scheme based on radiographs of developing permanent molariform teeth." Journal of Zoology London 225 (1991): 85-97.

36. Bryant J.D. et al. "Biologic and climatic signals in the oxygen isotopic composition of EoceneOligocene equid enamel phosphate." Palaeogeography, Palaeoclimatology, Palaeoecology 126.12 (1996): 75-89.

37. Bryant J.P. et al. "Can antibrowsing defense regulate the spread of woody vegetation in arctic tundra?." Ecography 37.3 (2014): 204-211.

38. Callaghan T.V., and Johansson M. "In species and communities in extreme environments." S.I. Golovatch et al. Eds. Pensoft, Moscow (2009): 13-52.

39. Ceballos G., Ehrlich P.R., Barnosky A.D., Garcia A., Pringle R.M., and Palmer T.M. "Accelerated modern human-induced species losses: Entering the sixth mass extinction." Sci. Adv. (2015): e1400253

40. Cerling T.E., and Harris J.M. "Carbon isotopes in bioapatite of ungulate mammals: implications for ecological and paleoecological studies." J. Vert. Paleontol., Abstr. Pap. 18 (1998): 33A. 
41. Cerling T.E., Harris J.M., and Leakey M.G. "Isotope paleoecology of the Nawata and Nachukui Formations at Lothagam, Turkana Basin, Kenya." Lothagam: The Dawn of Humanity in Eastern Africa. Columbia University Press, New York (2001): 605624.

42. Cerling T.E., Harris J.M., MacFadden B.J., Leakey M.G., Quade J., Eisenmann V., and Ehleringer J.R. "Global vegetation through the Miocene/Pliocene boundary." Nature 389 (1997): 153- 158.

43. Chen P.Y., Stokes A.G., and McKittrick J. "Comparison of the structure and mechanical properties of bovine femur bone and antler of the North American Elk (Cervus elaphus canadensis)." Acta Biomaterialia 5 (2009): 693-706.

44. Christensen T.R. et al. "A catchment-scale carbon and greenhouse gas budget of a subarctic landscape." Philosophical Transactions of the Royal Society of London A: Mathematical, Physical and Engineering Sciences 365.1856 (2007): 1643-1656.

45. Chritz K.L. et al. "Palaeobiology of an extinct Ice Age mammal: Stable isotope and cementum analysis of giant deer teeth." Palaeogeography, Palaeoclimatology, Palaeoecology 282.1-4 (2009): 133-144.

46. Clark I, and Fritz P. Environmental Isotopes in Hydrogeology. Lewis Publishers New York (1997): 63-77.

47. Clark P.U. et al. "The last glacial maximum." Science 325.5941 (2009): 710-714.

48. Clementz M.T., Fox-Dobbs K., Wheatley P.V., Koch P.L., and Doak D.F. "Revisiting old bones: Coupled carbon isotope analysis of bioapatite and collagen as an ecological and palaeoecological tool." Geological Journal 44 (2009): 605-620.

49. Clutton-Brock T. H. "The functions of antlers." Behaviour 79.2 (1982): 108-124.

50. Committee on the Status of Endangered Wildlife in Canada, 2014. "Caribou (Rangifer Tarandus) COSEWIC Assessment and Status Report 2014: Chapter 1." Government of Canada, Innovation, Science and Economic Development Canada, 5 June 2017, <www.canada.ca/en/environmentclimate-change/services/species-risk-public-registry/cosewic-assessments-statusreports/caribou2014/chapter-1.html>

51. Committee on the Status of Endangered Wildlife in Canada, 2020. "Endangered Species Registry." Government of Canada, Innovation, Science and Economic Development Canada, 25 July 2020 $<$ https://speciesregistry.canada.ca/indexen.html\#/species?cosewicStatusld=3\&sortBy=commonN ameSort\&sortDirection=asc\&pageSize $=10>$

52. Codron D., Clauss M., Codron J., and Tutken T. "Within trophic level shifts in collagen-carbonate stable carbon isotope spacing are propagated by diet and digestive physiology in large mammal herbivores." Ecology and Evolution 8:8 (2018): 3983-3995.

53. Codron J., Codron D., Sponheimer M., Kirkman K., Duffy K. J., Raubenheimer E. J., and Lee-Thorp J.A. "Stable isotope series from elephant ivory reveal lifetime histories of a true dietary generalist." Proceedings of the Royal Society B 279 (2012): 2433-2441.

54. Cooper A. et al. "Abrupt warming events drove Late Pleistocene Holarctic megafaunal turnover." Science 349.6248 (2015): 602-606.

55. Cormie A.B., and Schwarcz H.P. "Effects of climate on deer bone $\delta^{15} \mathrm{~N}$ and $\delta^{13} \mathrm{C}$ : lack of precipitation effects on $\delta^{15} \mathrm{~N}$ for animals consuming low amounts of $\mathrm{C}_{4}$ plants." Geochimica et Cosmochimica Acta 60.21 (1996): 4161-4166.

56. Craine J.M. et al. "Convergence of soil nitrogen isotopes across global climate gradients." Scientific Reports 5.8280 (2015): 1-8.

57. Cuyler C. et al. "Are warbles and bots related to reproductive status in West Greenland caribou?" Rangifer 32.2 (2012): 243-257.

58. Dansgaard W. "Stable isotopes in precipitation." Tellus 16.4 (1964): 436-468. 
59. Day T.A., Ruhland C.T., and Xiong F.S. "Warming increases aboveground plant biomass and C stocks in vascular-plant-dominated Antarctic tundra." Global Change Biology 14.8 (2008): 1827 1843.

60. Dauphiné Jr. T. C. (1973). Biology of the Kaminuriak Population of the Barren-Ground Caribou Part 3: Growth, Reproduction, and Nutritional Composition. Environment Canada Wildlife Services, Report Series - Number 20.

61. Davidson R., Simard M., Kutz S.J., Kapel C.M.O., Hamnes I.S., and Robertson L.J. “Arctic Parasitology: Why should we care?" Trends Parasitol. 27.6 (2011): 238-244.

62. DeMars, C.A., and Boutin S. "Nowhere to hide: Effects of linear features on predator-prey dynamics in a large mammal system. "Journal of Animal Ecology 87.1 (2018): 274-284.

63. DeNiro M.J., and Epstein S. "Influence of diet on the distribution of nitrogen isotopes in animals." Geochimica et cosmochimica acta 45.3 (1981): 341-351.

64. DeNiro M.J., and Hastorf C. "Alteration of ${ }^{15} \mathrm{~N} /{ }^{14} \mathrm{~N}$ and ${ }^{13} \mathrm{C} /{ }^{12} \mathrm{C}$ ratios of plant matter during the initial stages of diagenesis: studies using archaeological specimens from Peru." Geochim Cosmochim. Acta 49 (1985): 97-115.

65. Denryter K.A., Cook R.C., Cook J.G., and Parker K.L. "Straight from the caribou's (Rangifer tarandus) mouth: Detailed observations of tame caribou reveal new insights into summerautumn diets." Canadian Journal of Zoology 95 (2017): 81-94.

66. Dickie M. et al. "Faster and farther: wolf movement on linear features and implications for hunting behaviour." Journal of Applied Ecology 54.1 (2017): 253-263.

67. Dirzo R., Young H.S., Galetti M., Ceballos G., Isaac N., and Collen B. "Defaunation in the Anthropocene." Science 25.345 (2014): 401-406.

68. Drucker D.G. et al. "Intra-individual variation in stable carbon $\left(\delta^{13} \mathrm{C}\right)$ and nitrogen $\left(\delta^{15} \mathrm{~N}\right)$ isotopes in mandibles of modern caribou of Qamanirjuaq (Rangifer tarandus groenlandicus) and Banks Island (Rangifer tarandus pearyi): Implications for tracing seasonal and temporal changes in diet." International Journal of Osteoarchaeology 22.4 (2012): 494-504.

69. Drucker D.G., Hobson K.A., Ouellet J.P., and Courtois R. "Influence of forage preferences and habitat use on ${ }^{13} \mathrm{C}$ and ${ }^{15} \mathrm{~N}$ abundance in wild caribou (Rangifer tarandus caribou) and moose (Alces alces) from Canada." Isotopes in Environmental and Health Studies 46.1 (2010): 107-121.

70. Dungait J.A.J., Docherty G., Straker V., and Evershed R.P. "Interspecific variation in bulk tissue, fatty acid and monosaccharide $\delta^{13} \mathrm{C}$ values of leaves from a mesotrophic grassland plant community." Phytochemistry 69 (2008): 2041-2051.

71. Eisenmann D.R. “Amelogenesis". In Oral Histology (ed. A. R. Ten Cate). Mosby Company, St. Louis, 1985

72. Ehleringer J.R., Cerling T.E., and Helliker B.R. " $\mathrm{C}_{4}$ photosynthesis, atmospheric $\mathrm{CO}_{2}$, and climate." Oecologia 112 (1997): 285-299.

73. Ehleringer J.R., and Rundel P.W. Stable Isotopes in Ecological Research. Springer-Verlag, New York Inc (1988): 1-142.

74. Ehleringer J.R., and Rundel P.W. "Stable Isotopes: history, units, and instrumentation." In Stable isotopes in ecological research. Edited by P.W. Rundel, J.R. Rundel, and K.A. Nagy. SpringerVerlag, New York (1989): 1-16.

75. Ehleringer J.R. ${ }^{13} \mathrm{C} /{ }^{12} \mathrm{C}$ fractionation and its utility in terrestrial plant studies. " Carbon isotope techniques 1 (1991): 187.

76. Elliott K.H. and Elliott J.E. "Lipid extraction techniques for stable isotope analysis of bird eggs: Chloroform-methanol leads to more enriched ${ }^{13} \mathrm{C}$ values than extraction via petroleum ether." Journal of Experimental Marine Biology and Ecology 474 (2016): 54-57.

77. Ellis S. "Pleurozium schreberi." Introduction to Bryophytes: The Public Face of Biology 321. Faculty of Science, University of British Columbia < http://blogs.ubc.ca/biology321/?page_id=974> 
78. Eriksen E.F. "Cellular mechanisms of bone remodeling." Reviews in Endocrine and Metabolic Disorders 11.4 (2010): 219 - 227.

79. Eriksen E.F. et al. "Cancellous bone remodeling in type I (postmenopausal) osteoporosis: quantitative assessment of rates of formation, resorption, and bone loss at tissue and cellular levels." Journal of Bone and Mineral Research 5.4 (1990): 311-319.

80. Espmark Y. "Studies in dominance-subordination relationship in a group of semi-domestic reindeer (Rangifer tarandus L.)." Animal Behaviour 12.4 (1964): 420-426.

81. Evans E. "Annual Report 2018/2019." Beverly and Qamanirjuaq Caribou Management Board (2019): 1-34.

82. Farquhar G.D., Ehleringer J.R., and Hubick K.T. "Carbon isotope discrimination and photosynthesis." Annual review of plant biology 40.1 (1989): 503-537.

83. Fauchald P., Park T., Tømmervik H., Myneni R., and Hausner V.H. "Arctic greening from warming promotes decline in caribou populations." Sci. Adv. 3:4 (2017).

84. Festa-Bianchet M., Ray J.C., Boutin S., Cote S.D., and Gunn A. "Conservation of caribou (Rangifer tarandus) in Canada: an uncertain future." Can. Jour. Zool. 89 (2011): 419-434.

85. Fleming T.H., Nunez R.A., and Sternberg L.S.L. "Seasonal changes in the diets of migrant and nonmigrant nectarivorous bats as revealed by carbon isotope analysis." Oceologia 94 (1993): 72-75.

86. Freyer H.D. "On the ${ }^{13} \mathrm{C}$-record in tree rings: ${ }^{13} \mathrm{C}$ Variations in northern hemisphere trees during the last 150 years." Tellus 31 (1979): 124-137.

87. Fricke H.C., and O'Niel J.R. "Inter- and intra-tooth variation in the oxygen isotope composition of mammalian tooth enamel phosphate: Implications for palaeoclimatological and palaeobiological research." Palaeogeogr. Palaeocl. 126 (1996): 91-99.

88. Freyer H.D., and Belacy N. ${ }^{13} \mathrm{C} /{ }^{12} \mathrm{C}$ records in northern hemispheric trees during the past 500 years - anthropogenic impact and climate superpositions." Jour. Geophys. Res. 88 (1983): 68449852.

89. Fricke H.C., Clyde W.C., and O'Neil J.R. "Intra-tooth variations in 180(PO4) of mammalian tooth enamel as a record of seasonal variations in continental climate variables." Geochim. Cosmochim. Acta. 62 (1998): 1839-1850.

90. Froehle A.W., Kellner C.M., and Schoeninger M.J. "FOCUS: Effect of diet and protein source on carbon stable isotope ratios in collagen: Follow up to Warinner and Tuross (2009)." Journal of Archaeological Science 37 (2010): 2662-2670.

91. Fry, Brian. Stable isotope ecology. Vol. 521. New York: Springer, 2006.

92. Gannes L.Z., O'Brien D.M., and Martinez Del Rio C. "Stable isotopes in animal ecology: assumptions, caveats, and a call for more laboratory experiments." Ecology 78.4 (1997): 1271 1276.

93. Gerhart K.L., White R.G., Cameron R.D., and Russell D.E. "Body composition and nutrient reserves of arctic caribou." Canadian Journal of Zoology 74 (1996): 136-146.

94. Gilg O. et al. "Climate change and the ecology and evolution of Arctic vertebrates." Ann. NY Acad. Sci. 1249 (2012): 166-190.

95. Gilg O., Sittler B., and Hanski I. "Climate change and cyclic predator-prey population dynamics in the high Arctic." Glob. Change Biol. 15 (2009): 2634-2652.

96. Goss R.J. Deer antlers: regeneration, function and evolution. New York Academic Press Inc., 1983.

97. Graversen R.G., and Wang M. "Polar amplification in a coupled climate model with locked albedo." Clim Dyn 33 (2009): 629-643.

98. Griffith B., Gunn A., Russel D., Johnstone J., Kielland K., Wolfe S., and Douglas D.C. "Bathurst caribou calving ground studies: Influence of nutrition and human activity on calving ground location." Final report to the West Kitikmeot Slave Study Society, Yellowknife (2002).

99. Griscom B.W. "Natural Climate Solutions." Proceedings of the National Academy of Sciences USA 114.44 (2017): 11645-11650. 
100.Gross M. "Megafauna moves nutrients uphill." (2016): R1-R5.

101.Guthrie R.D. "Frozen fauna of the mammoth steppe: Chicago and London." The University of Chicago Press 323 (1990): 111-112.

102.Guthrie R.D. "New carbon dates link climatic change with human colonization and Pleistocene extinctions." Nature 441.7090 (2006): 207.

103. Hall A. "The Role of Surface Albedo Feedback in Climate." J Clim 17 (2004): 1550-1568.

104. Handley L.L. et al. "The ${ }^{15} \mathrm{~N}$ natural abundance $\left(\delta^{15} \mathrm{~N}\right)$ of ecosystem samples reflects measures of water availability." Functional Plant Biology 26.2 (1999): 185-199.

105. Heckeberg N.S. "Origination of antlerogenesis." Journal of morphology 278.2 (2017): 182-202.

106. Hedges R.E.M. "On bone collagen-apatite-carbonate isotopic relationships." International Journal of Osteoarchaeology 13 (2003): 66-79.

107. Hedges R.E.M. et al. "Collagen turnover in the adult femoral mid-shaft: modeled from anthropogenic radiocarbon tracer measurements." American Journal of Physical Anthropology: The Official Publication of the American Association of Physical Anthropologists 133.2 (2007): 808-816.

108. Heimann M., and Maier-Reimer E. "On the relations between oceanic uptake of $\mathrm{CO}_{2}$ and its carbon isotopes." Global Biogeochemical cycles 10:1 (1996): 89-110.

109. Helliker B.R., and Ehleringer J.R. "Establishing a grassland signature in veins: ${ }^{18} \mathrm{O}$ in the leaf water of $C_{3}$ and $C_{4}$ grasses." Proceedings of the National Academy of Sciences 97.14 (2000): 7894-7898.

110. Higgins P., and MacFadden B.J. "'Amount Effect" recorded in oxygen isotopes of Late Glacial horse (Equus) and bison (Bison) teeth from the Sonoran and Chihuahuan deserts, southwestern United States." Palaeogeography, Palaeoclimatology, Palaeoecology 206.3-4 (2004): 337-353.

111. Hobson K.A., and Wassenaar L.I. "Stable Isotope Ecology: An Introduction." Oecologia 120 (1999): 312-313.

112. Hobson K.A., and Clark R.G. "Assessing avian diets using stable isotopes II: factors influencing diet-tissue fractionation." Condor (1992): 189-197.

113. Hobson K.A. et al. "Stable carbon and nitrogen isotopic fractionation between diet and tissues of captive seals: implications for dietary reconstructions involving marine mammals." Canadian Journal of Fisheries and Aquatic Sciences 53.3 (1996): 528-533.

114. Hobson K.A., and Welch H.E. "Determination of Trophic Relationships within a High Arctic Marine Food Web Using $\delta^{13} \mathrm{C}$ and $\delta^{15} \mathrm{~N}$ analysis." Mar. Ecol. 84 (1992): 9-18.

115. Hoefs J. Stable Isotope Geochemisty Sixth Edition. Springer-Verlag Berlin Heidelberg (2009).

116. Högberg P. "15N natural abundance in soil-plant systems." New Phytologist 137 (1997): 179-203.

117. Hughes J. et al. "Is there a cost of parasites to caribou?" Parasitology 136.2 (2009): 253-265.

118. Iacumin P., Bocherens H., Delgado Huertes A., Mariotti A., and Longinelli A. "A stable isotope study of fossil mammal remains from the Paglicci cave, Southern Italy. $\mathrm{N}$ and $\mathrm{C}$ as palaeoenvironmental indicators." Earth Planet Sci Lett 148 (1997): 349-357.

119. lacumin P., Nikolaev V., and Ramigni M. "C and N stable isotope measurements on Eurasian fossil mammals, 40,000 to 10,000 years BP: herbivore physiologies and palaeoenvironmental reconstruction." Palaeogeog Palaeoclim Palaeoecol 163 (2000): 33-47.

120. Intergovernmental Science-Policy Platform on Biodiversity and Ecosystem Services (IPBES), 2020. "Nature's Dangerous Decline Unprecedented Species Extinction Rates Accelerating." United Nations Environment Program, 6 July 2020, < https://ipbes.net/news/Media-Release-GlobalAssessment>

121.Ims R.A. and Fuglei E. "Trophic interaction cycles in tundra ecosystems and the impact of climate change." Bioscience 55 (2005): 311-322.

122. Ims R.A. and Steen H. "Geographical synchrony in microtine population cycles: a theoretical evaluation of the role of nomadic avian predators." Oikos 57 (1990): 381-387. 
123.Jepsen J.U. et al. "Climate change and outbreaks of the geometrids Operophtera brumata and Epirrita autumnata in subarctic birch forest: evidence of a recent outbreak range expansion." Journal of Animal Ecology 77.2 (2008): 257-264.

124.Joly K., Duffy P.A., and Rupp T.S. "Simulating the effects of climate change on fire regimes in Arctic biomes: implications for caribou and moose habitat." Ecosphere 3.5 (2012): 1-18.

125.Josephsen K., and Fejerskov O. "Ameloblast modulation in the maturation zone of the rat incisor enamel organ. A light and electron microscopic study." Journal of anatomy 124.Pt 1 (1977): 45.

126. Karaev G.I. "Reindeer fodder resources." Reindeer Husbandy. US. Department of Commerce Springfield, Virginia. (1968).

127. Kelly J.F. "Stable isotopes of carbon and nitrogen in the study of avian and mammalian trophic ecology." Canadian journal of zoology 78.1 (2000): 1-27.

128. Kendrew V.G., and Currie B.W. The Climate of Central Canada. Queen's Printer, Ottawa (1955).

129. Kierdorf U. et al. "Histological studies of bone formation during pedicle restoration and early antler regeneration in roe deer and fallow deer." The Anatomical Record Part A: Discoveries in Molecular, Cellular, and Evolutionary Biology: An Official Publication of the American Association of Anatomists 273.2 (2003): 741-751.

130. Kiltie R.A. "Evolution and function of horns and hornlike organs in female ungulates." Biological Journal of the Linnean Society 24.4 (1985): 299-320.

131. Klein D.R. "Tundra ranges north of the boreal forest." Journal of Range Management (1970): 814.

132. Koch P.L. "Isotopic reconstruction of past continental environments." Annual Review of Earth and Planetary Sciences 26.1 (1998): 573-613.

133. Koch P.L. "Isotopic study of the biology of modern and fossil vertebrates." Stable isotopes in ecology and environmental science (2007): 99-154.

134. Koch P.L., Tuross N., and Fogel M.L. "The Effects of Sample Treatment and Diagenesis on the Isotopic Integrity of Carbonate in Biogenic Hydroxylapatite." Journal of Archaeological Science 24 (1997): 417-429.

135. Koch P.L., Zachos J.C. and Gingerich P.D. “Correlation between isotope records in marine and continental carbon reservoirs near the Palaeocene/Eocene boundary." Nature 358 (1992): 319322.

136. Kohn M.J. “Comment: Tooth enamel mineralization in ungulates: Implications for recovering a primary isotopic time-series, by B. H. Passey and T. E. Cerling (2002)." Geochimica et Cosmochimica Acta 68:2 (2004): 403-405.

137. Kohn M.J. "Predicting animal d180: accounting for diet and physiological adaptation." Geochimica et Cosmochimica Acta 60.23 (1996): 4811-4829.

138. Kohn M.J. "Carbon isotope compositions of terrestrial C3 plants as indicators of (paleo) ecology and (paleo) climate." Proceedings of the National Academy of Sciences 107.46 (2010): 1969119695.

139. Kohn M.J., and Cerling T.E. "Stable isotope compositions of biological apatite." Reviews in mineralogy and geochemistry 48.1 (2002): 455-488.

140. Komori T. et al. "Targeted disruption of Cbfa1 results in a complete lack of bone formation owing to maturational arrest of osteoblasts." cell 89.5 (1997): 755-764.

141. Krauss S. et al. "Tubular frameworks guiding orderly bone formation in the antler of the red deer (Cervus elaphus)." Journal of structural biology 175.3 (2011): 457-464.

142. Kristensen D.K., Kristensen E., Forchhammer M.C., Michelsen A., and Schmidt N.M. "Arctic herbivore diet can be inferred from stable carbon and nitrogen isotopes in $C_{3}$ plants, faeces, and wool." Canadian Journal of Zoology 89 (2011): 892-899. 
143. Kutz S.J., Jenkins E.J., Veitch A.M., Ducrocq J., Polley L., Elkin B., and Lair S. "The Arctic as a model for anticipating, preventing, and mitigating climate change impacts on host - parasite interactions." Vet. Parasitol. 163 (2009): 217-228.

144.Lajtha K., and Marshall J.D. "Sources of variation in the stable isotopic composition of plants." Stable isotopes in ecology and environmental science (1994): 1-21.

145.Lange O.L., Green T.G.A., and Ziegler H. "Water status related photosynthesis and carbon isotope discrimination in species of the lichen genus Pseudocyphellaria with green or blue-green photobionts and in photosymbiodemes." Oecologia 75.4 (1988): 494-501.

146. Lantis M. "The reindeer industry in Alaska." Arctic 3.1 (1950): 27-44.

147. Larsen J.A. "The vegetation of the Ennedai Lake Area, N.W.T: Studies in subarctic and Arctic Bioclimatology." Ecol. Monographs 35 (1965): 37-59.

148. Latham A.D.M. et al. "Wolves, white-tailed deer, and beaver: implications of seasonal prey switching for woodland caribou declines." Ecography 36.12 (2013): 1276-1290.

149.Launchbaugh K.L., and Urness P.J. "Mushroom consumption (Mycophagy) by North American Cervids." The Great Basin Naturalist 54 (199): 321-327.

150. Lawler J.P., and White R.G. "Effect of browse on post-ingestive energy loss in an Arctic ruminant: implications for muskoxen (Ovibos moschatus) in relation to vegetation change." Canadian journal of zoology 84.11 (2006): 1657-1667.

151.Li C., Suttie J.M., and Clark D.E. "Morphological observation of antler regeneration in red deer (Cervus elaphus)." Journal of Morphology 262.3 (2004): 731-740.

152. Li C., Suttie J.M., and Clark D.E. "Histological examination of antler regeneration in red deer (Cervus elaphus)." The Anatomical Record Part A: Discoveries in Molecular, Cellular, and Evolutionary Biology: An Official Publication of the American Association of Anatomists 282.2 (2005): 163-174.

153.Lincoln G.A. "Biology of antlers." Journal of Zoology 226.3 (1992): 517-528.

154.Logan J.M., and Lutcavage M.E. "A comparison of carbon and nitrogen stable isotope ratios of fish tissues following lipid extraction with non-polar and traditional chloroform/methanol solvent systems." Rapid Commun. Mass Spectrom. 22 (2008): 1081-1086.

155.Long E.S., Sweitzer R.A., Diefenbach D.R., and Ben-David M. "Controlling for anthropogenically induced atmospheric variation in stable carbon isotope studies." Oecologia 146 (2005): 148-156.

156.Longin R. "New method of collagen extraction for radiocarbon dating." Nature (1971): 230-241.

157.Lorenzen E.D. et al. "Species-specific responses of Late Quaternary megafauna to climate and humans." Nature 479.7373 (2011): 359.

158. MacFadden B.J., Cerling T.E., Harris J.M., and Prado J. "Ancient latitudinal gradients of $C_{3} / C_{4}$ grasses interpreted from stable isotopes of New World Pleistocene horse (Equus) teeth." Global Ecology and Biogeography 8 (1999): 137-149.

159. Macias-Fauria M., Japson P., Zimov N., and Malhi Y. "Pleistocene Arctic Megafaunal Ecological Engineering as a Natural Climate Solution?" Philosophical Transactions of the Royal Society B 375 (2020): 1- 13.

160. Macko S.A., Helleur R., Hartley G., and Jackman P. “Diagenesis of organic matter - A study using stable isotopes of individual carbohydrates." Organic Geochemistry 16.2-6 (1990): 1129-1137.

161. Mallory C.D., and Boyce M.S. "Observed and predicted effects of climate change on Arctic caribou and reindeer." Environmental Reviews 26.1 (2017): 13-25.

162. Mann D.H. et al. "Ice-age megafauna in Arctic Alaska: extinction, invasion, survival." Quaternary Science Reviews 70 (2013): 91-108.

163. Mariotti A. et al. "The abundance of natural nitrogen 15 in the organic matter of soils along an altitudinal gradient (Chablais, Haute Savoie, France)." Catena 7.4 (1980): 293-300.

164. Markusson E., and Folstad I. "Reindeer antlers: visual indicators of individual quality?" Oecologia 110.4 (1997): 501-507. 
165. Marshall J.D., Brooks J.R., and Lajtha, K. "Sources of variation in the stable isotopic composition of plants." In Stable isotopes in ecology and environmental science. 2nd ed. Blackwell Publishing, Malden, Mass. (2007): 22-60.

166. Martin P.S., and Klein R.G. eds. Quaternary extinctions: a prehistoric revolution. University of Arizona Press, 1984 \& 1989.

167. Martinelli L.A. et al. "Nitrogen Stable Isotopic Composition of Leaves and Soil: Tropical Versus Temperate Forests." Biogeochemistry 46 (1999): 45-65.

168. Matsubayashi J., and Tayasu I. "Collagen turnover and isotopic records in cortical bone." Journal of Archaeological Science 106 (2019): 37-44.

169. Matveyeva N.V., and Chernov Y. "Zonation in plant cover of the arctic." Russian Academy of Science, Moscow (2000): 219.

170.McCrea J.M. "On the isotopic chemistry of carbonates and a paleotemperature scale." The Journal of Chemical Physics 18.6 (1950): 849-857.

171. McLoughlin P.D. et al. "Declines in populations of woodland caribou." The Journal of wildlife management (2003): 755-761.

172. McLeman C.I.A. "Determining the relationships between forage use, climate and nutritional status of barren ground caribou, Rangifer tarandus groenlandicus, on Southampton Island, Nunavut, using stable isotopes analysis of $\delta^{13} \mathrm{C}$ and $\delta^{15} \mathrm{~N}$." MSc Thesis in Biology, University of Waterloo, Ontario, Canada (2006).

173. Mendoze M. \& Araújo M.B. "Climate shapes mammal community trophic structures and humans simplify them." Nature communications 10 (2019): 1-9.

174. Miller D.R. "Biology of the Kaminuriak Population of the Barren-Ground Caribou Part 4: Taiga Winter Range Relationships and Diet." Environment Canada Wildlife Services, Report Series Number 20 (1973).

175. Miller F.L. "Biology of the Kaminuriak Population of the Barren-Ground Caribou Part 2: Age and Sex Composition and Segregation of the Population." Environment Canada Wildlife Services, Report Series - Number 20 (1973).

176. Milligan $\mathrm{H}$. "Aquatic and terrestrial foraging by a subarctic herbivore: The beaver." MSc Thesis in Science, University of McGill, Quebec Canada (2008).

177. Minagawa M., and Wada E. "Stepwise enrichment of ${ }^{15} \mathrm{~N}$ along food chains: further evidence and the relation between $\delta^{15} \mathrm{~N}$ and animal age." Geochimica et cosmochimica acta 48.5 (1984): 11351140.

178. Mississippi State University: Deer Ecology and Management Lab, 2020 "Antler Growth Cycle." Mississippi State University, Forest and Wildlife Research Center, Mississippi State, 25 July 2020 <https://www.msudeer.msstate.edu/growth-cycle.php>

179. Mizutani H., Kabaya Y., and Wada E. "Nitrogen and Carbon isotope compositions relate linearly in cormorant tissues and its diet." Isotopenpraxis 27 (1992): 166-168.

180. Mizutani H., and Wada E. "Nitrogen and carbon isotope ratios in seabird rookeries and their ecological implications." Ecology 69 (1988): 340-349

181. Moore G.W.K. "Reduction in seasonal sea ice concentration surrounding southern Baffin Island 1979-2004." Geophysical Research Letters 33.20 (2006).

182. Nadelhoffer K.J., and Fry B. "Nitrogen isotope studies in forest ecosystems." Stable isotopes in ecology and environmental sciences (1994): 22-44.

183. National Snow \& Ice Data Center, 2020. "Climate Change in the Arctic." World Data System, International Science Council, 25 July $2020<$ https://nsidc.org/cryosphere/arcticmeteorology/climate_change.html>

184. Nicholson K.L. et al. "Modeling caribou movements: seasonal ranges and migration routes of the Central Arctic Herd." PloS one 11.4 (2016): e0150333. 
185.O'Connell T.C., Hedges R.E.M., Healey M.A., and Simpson A.H.R.W. "Isotopic comparison of hair, nail and bone: modern analyses." J. Archaeol. Sci. 28 (2001): 1247.

186.O'Leary M.H. "Carbon isotope fractionation in plants." Phytochemistry 20.4 (1981): 553-567.

187.O'Leary M.H. "Carbon isotopes in photosynthesis." Bioscience 38.5 (1988): 328-336.

188.Pachkowski M., Côté S.D., and Festa-Bianchet M. "Spring-loaded reproduction: effects of body condition and population size on fertility in migratory caribou (Rangifer tarandus)." Canadian Journal of Zoology 91.7 (2013): 473-479.

189.Parker G.R. "Biology of the Kaminuriak Population of the Barren-Ground Caribou Part 1: Total Numbers, Mortality, Recruitment and Seasonal Distribution." Environment Canada Wildlife Services, Report Series - Number 20 (1973).

190.Parker K.L., Barboza P.S., and Stephenson T.R. "Protein Conservation in Female Caribou (Rangifer tarandus): Effects of Decreasing Diet Quality During Winter." Journal of Mammalogy 86:3 (2005) 610-622.

191.Parkinson C.L., and Cavalieri D.J. "Arctic sea ice variability and trends, 1979-2006." Journal of Geophysical Research: Oceans 113.C7 (2008).

192. Parlee B.L., Sandlos J., and Natcher D.C. "Undermining subsistence: Barren-ground caribou in a "tragedy of open access"." Science Advances 4 (2018): 1-14.

193. Parmesan C. "Ecological and Evolutionary Responses to Recent Climate Change." Anu. Rev. Ecol. Evol. Syst. 37 (2006): 637-669.

194.Pasda K. "Bone growth throughout the lifetime of reindeer." Archaeozoology (2009).

195. Passey B.H., Robinson T.F., Ayliffe L.K., Cerling T.E. Sponheimer M., Dearing M.D., and Ehleringer J.R. "Carbon isotope fractionation between diet, breath $\mathrm{CO} 2$, and bioapatite in different animals." Journal of Archaeological Science 32 (2005): 1459-1470.

196. Passey B.H., and Cerling T.E. "Tooth enamel mineralization in ungulates: implications for recovering a primary isotopic time-series." Geochimica et Cosmochimica Acta 66.18 (2002): 32253234.

197.Peterson B.J., and Fry B. "Stable isotopes in ecosystem studies." Annual review of ecology and systematics 18.1 (1987): 293-320.

198. Phelan J. What is Life?: A Guide to Biology with Physiology. W H Freeman \& Co; $3^{\text {rd }}$ Edition (2014): 784.

199.Podlesak D.W., Torregrossa A.M., Ehleringer J.R., Dearing M.D., Passey B.H., Cerling T.E. "Turnover of oxygen and hydrogen isotopes in the body water, $\mathrm{CO}_{2}$, hair, and enamel of a small mammal." Cosmochimica Acta 72.1 (2008): 19-35.

200. Polley L., and Thompson R.C.A. "Parasite zoonoses and climate change: molecular tools for tracking shifting boundaries." Trends Parasitol. 25 (2009): 285-291.

201.Post E., and Pedersen C. "Opposing plant community responses to warming with and without herbivores." Proceedings of the National Academy of Sciences 105.34 (2008): 12353-12358.

202. Post E., and Forchhammer C. "Climate change reduces reproductive success of an Arctic herbivore through trophic mismatch." Philos. Trans. R. Soc. B 363 (2008): 2369.

203. Post E. et al. "Ecological dynamics across the Arctic associated with recent climate change." Science 325.5946 (2009): 1355-1358.

204. Quade J. et al. "A 16 million year record of paleodiet from Pakistan using carbon isotopes in fossil teeth." Chem. Geol 94 (1992): 183-192.

205. Rabanus-Wallace M.T. et al. "Megafaunal isotopes reveal role of increased moisture on rangeland during late Pleistocene extinctions." Nature ecology \& evolution 1.5 (2017): 01-25.

206. Richards M.P., and Hedges R.E.M. "Variations in bone collagen $13 \mathrm{C}$ and $15 \mathrm{~N}$ values of fauna from Northwest Europe over the last 40,000 years." Palaeogeog Palaeoclim Palaeoecol 193 (2003): 261-267. 
207.Rindsberger M.S., Jaffe S., Rahamin S., and Gat J.R. "Patterns of the isotopic composition of precipitation in time and space; data from the Israeli storm water collection program." Tellus 42 (1990): 263-27.

208. Rivera-Araya M., and Birch S.P. "Stable isotope signatures in white-tailed deer as a seasonal paleoenvironmental proxy: A case study from Georgia, United States." Palaeogeography, Palaeoclimatology, Palaeoecology 505 (2018): 53-62.

209. Roberts S.C. "The evolution of hornedness in female ruminants." Behaviour 133.5 (1996): 399442.

210. Rozanski K., Araguás-Araguás L., and Gonfiantini R. "Isotopic patterns in modern global precipitation." Climate change in continental isotopic records 78 (1993): 1-36.

211.Schaefer J.A., and Mahoney S.P. "Antlers on female caribou: biogeography of the bones of contention." Ecology 82.12 (2001): 3556-3560.

212.Schmidt N.M., Ims R.A., Hoye T.T., Gilg O., Hansen L.H., Hansen J., Lund M., Fuglei E., Forchhammer M.C., and Sittler B. "Response of an arctic predator guild to collapsing lemming cycles." Proceedings of the Royal Society B 279 (2012): 4417-4422.

213.Schoeninger M.J., and DeNiro M.J. "Nitrogen and carbon isotopic composition of bone collagen from marine and terrestrial animals." Geochim. Cosmochim. Acta 48 (1984): 625-639.

214.Schwarcz H.P. "Some theoretical aspects of isotope paleodiet studies." Journal of Archaeological Science 18.3 (1991): 261-275.

215.Sealy J.C. et al. "Nitrogen isotopic ecology in southern Africa: implications for environmental and dietary tracing." Geochimica et Cosmochimica Acta 51.10 (1987): 2707-2717.

216.Shah S.R., DesJardins J.D., and Blob R.W. "Antler stiffness in caribou (Rangifer tarandus): testing variation in bone material properties between males and females." Zoology 111.6 (2008): 476482.

217.Shearer G., Kohl D.H., and Chien S.H. "The Nitrogen-15 Abundance in a Wide Variety of Soils 1." Soil Science Society of America Journal 42.6 (1978): 899-902.

218.Sher A.V. "Natural reconstruction in east-Siberian Arctic on the border of Pleistocene and Holocene and its role in the mammals extinction and forming of modern ecosystems." Cryosphere of the Earth 1 (1997): 21-29.

219.Skogland T. "The effects of density-dependent resource limitations on the demography of wild reindeer." Journ. Animal Ecology 54 (1985): 359-374.

220.Soveri T., Sankari S., and Nieminens M. "Blood chemistry of reindeer calves (Rangifer tarandus) during the winter season." Comp. Biochem. Physiol. 102A (1992): 191-196.

221.Sowers T. "Atmospheric methane isotope records covering the Holocene period." Quaternary Science Reviews 29.1-2 (2010): 213-221.

222.Sternberg, L.S.L. "Oxygen and hydrogen isotope ratios in plant cellulose: mechanisms and applications." Stable isotopes in ecological research. Springer, New York, NY. (1989): 124-141.

223.Stevens R.E., Jacobi R., Street M., Germonpre M., Conard N.J., Munzel S.C., and Hedges R.E.M. "Nitrogen isotope analyses of reindeer (Rangifer tarandus), 45,000 BP to 9,000 BP: Palaeoenvironmental reconstruction." Palaeogeography, Palaeoclimatology, Palaeoecology 262 (2008): 32-45.

224.Stevens R.E., and O'Connell T.C. "Red deer bone and antler collagen are not isotopically equivalent in carbon and nitrogen." Rapid Communications in Mass Spectrometry 30.17 (2016): 1969-1984.

225.Stuart A.J. "Mammalian extinctions in the Late Pleistocene of northern Eurasia and North America." Biological Reviews 66.4 (1991): 453-562.

226.Sturm M. et al. "Winter biological processes could help convert arctic tundra to shrubland." AIBS Bulletin 55.1 (2005): 17-26. 
227.Straight W.H., Barrick R.E., and Eberth D.A. "Reflections of surface water, seasonality and climate in stable oxygen isotopes from tyrannosaurid tooth enamel." Palaeogeography,

Palaeoclimatology, Palaeoecology 206.3-4 (2004): 239-256.

228. Takano Y., and Ozawa H. "Ultrastructural and cytochemical observations on the alternating morphologic changes of the ameloblasts at the stage of enamel maturation." Archivum histologicum japonicum 43.5 (1980): 385-399.

229.Taylor H.S. "Uses of the Separated Stable Isotopes of Oxygen." Proceedings of the American Philosophical Society 92.1 (1948): 1-5.

230.Terri J.A. "Polar Desert Adaptations of a High Arctic Plant Species." Science 179.4072 (1973): 496497.

231.Terri J.A., and Stowe L.G. "Climatic patterns and distribution of $\mathrm{C}_{4}$ grasses in North America." Oecologia 23 (1976): 1-12.

232.Tieszen L.L. et al. "Fractionation and turnover of stable carbon isotopes in animal tissues: implications for $\delta^{13} \mathrm{C}$ analysis of diet." Oecologia 57.1-2 (1983): 32-37.

233.Tieszen L.L., and Boutton T.W. "Stable carbon isotopes in terrestrial ecosystem research." Stable isotopes in ecological research. Springer, New York, NY. (1989): 167-195.

234. Tieszen L.L., and Fagre T. "Effect of diet quality and composition on the isotopic composition of respiratory $\mathrm{CO} 2$, bone collagen, bioapatite, and soft tissues." Prehistoric human bone. Springer, Berlin, Heidelberg. (1993): 121-155.

235. Thomas D.D., and Kiliaan H.P.L. "Warble infestations in some Canadian caribou and their significance." Rangifer 10.3 (1990): 409-417.

236. Thompson I.D., Wiebe P.A., Mallon E., Rodgers A.R., Fryxell J.M., Baker J.A., and Reid. D. "Factors influencing the seasonal diet selection by wood-land caribou (Rangifer tarandus tarandus) in boreal forests in Ontario." Canadian Journal of Zoology 93 (2015): 87-98.

237. Thompson D.P., and Barboza P.S. "Responses of caribou and reindeer (Rangifer tarandus) to acute food shortages in spring." Canadian journal of zoology 91.9 (2013): 610-618.

238. Thompson D.P., and Barboza P.S. "Nutritional implications of increased shrub cover for caribou (Rangifer tarandus) in the Arctic." Canadian Journal of Zoology 92.4 (2014): 339-351.

239. Thorp J.L., and Van Der Merwe N.J. "Carbon isotope analysis of fossil bone apatite." South African Journal of Science 83.11 (1987): 712-715.

240.Trenberth K.E. et al. "Contribution of working group I to the fourth assessment report of the intergovernmental panel on climate change, 2007." (2007).

241.Trudinger C.M., Enting I.G., Francey R.J., Etheridge D.M., and Rayner P.J. "Long-term variability in the global carbon cycle inferred from a high-precision $\mathrm{CO} 2$ and $\delta 13 \mathrm{C}$ ice-core record." Tellus 51 (1999): 233-248.

242.Tugarinov A.Y. "O proiskhozhdenii arkticheskoy fauny Evrazii." Priroda 7 (1929): 17-39.

243.Tyler N.J.C. "Climate, snow, ice, crashes, and declines in populations of reindeer and caribou (Rangifer tarandus L.)." Ecological Monographs 80.2 (2010): 197-219.

244. Uboni A. et al. "Long-term trends and role of climate in the population dynamics of Eurasian reindeer." PloS one 11.6 (2016): e0158359.

245.Van Der Merwe N.J., and Medina E. "Photosynthesis and ${ }^{13} \mathrm{C} /{ }^{12} \mathrm{C}$ ratios in Amazonian rain forests." Geochim. Cosmochim. Acta 53 (1989): 1091-1094

246.Van Der Wal M.R.N., Van Lieshout S., Dormann C., Langvatn R., and Albon S.D. "Trading forage quality for quantity? Plant phenology and patch choice by Svalbard reindeer." Oecologia 123 (2000): 108-115.

247.Van Der Wal R. "Do herbivores cause habitat degradation or vegetation state transition? Evidence from the tundra." Oikos 114.1 (2006): 177-186.

248. Van Der Wal R.E. et al. "Spring feeding by pink-footed geese reduces carbon stocks and sink strength in tundra ecosystems." Global Change Biology 13.2 (2007): 539-545. 
249.Vors L.S., and Boyce M.S. "Global declines of Caribou and Reindeer." Glob. Change Biol. 15 (2009): 2626-2633.

250. Water Isotope System for data analysis, visualization and Electronic Retrieval, 1993. "Global Network of Isotopes in Precipitation - Monthly CANADA: CHURCHILL (MANITOBA)." International Atomic Energy Agency. <https://nucleus.iaea.org/wiser/index.aspx>

251. Westerling B. "Rumen ciliate fauna of semi-domestic reindeer (Rangifer tarandus L.) in Finland: composition, volume and some seasonal variations." Acta Zool. Fenn. 127 (1970): 3-76.

252. Wislocki, G.B. "Studies on the growth of deer antlers. I. On the structure and histogenesis of the antlers of the Virginia deer (Odocoileus virginianus borealis)." American journal of anatomy 71.3 (1942): 371-415.

253. Wolfe, R.J. Local traditions and subsistence: A synopsis from twenty-five years of research by the State of Alaska. Juneau, AK: Alaska Department of Fish and Game, Division of Subsistence. (2004).

254. Wooller M.J. et al. "Stable carbon isotope compositions of Eastern Beringian grasses and sedges: investigating their potential as paleoenvironmental indicators. "Arctic, Antarctic, and Alpine Research 39.2 (2007): 318-331.

255. Wroe S. et al. "Megafaunal extinction in the late Quaternary and the global overkill hypothesis." Alcheringa 28.1 (2004): 291-331.

256. Yannic G. et al. "Genetic diversity in caribou linked to past and future climate change." Nature Climate Change 4.2 (2014): 132.

257.Zazula G.D. et al. "Palaeobotany: Ice-age steppe vegetation in east Beringia." Nature 423.6940 (2003): 603.

258.Zazzo A. et al. "Herbivore paleodiet and paleoenvironmental changes in Chad during the Pliocene using stable isotope ratios of tooth enamel carbonate." Paleobiology 26.2 (2000): 294-309.

259.Zhu Y. et al. "Phylogenetically balanced evidence for structural and carbon isotope responses in plants along elevational gradients." Oecologia 162.4 (2010): 853-863.

260.Zimov S.A., and Chupryninm V.I. "Ecosystems: steadiness, competition and purposeful transformation." (1991).

261.Zimov S.A. "Pleistocene park: return of the mammoth's ecosystem." Science 308.5723 (2005): 796-798.

262.Zimov S.A. et al. "Steppe-tundra transition: a herbivore-driven biome shift at the end of the Pleistocene." The American Naturalist 146.5 (1995): 765-794.

263.Zimov S.A. et al. "Mammoth steppe: a high-productivity phenomenon." Quaternary Science Reviews 57 (2012): 26-45. 


\section{Appendix 1: Carbonate Stable Isotope Data}

Individual samples represented by their CMN number (i.e. 39***). Samples with $A$ indicate powder collected along the length of the antler, B indicate samples collected along the mandible, $M$ indicate samples taken long the third molar, and finally TA indicate samples collected on the tine of the antler.

\begin{tabular}{|c|c|c|c|c|}
\hline & & $13 C$ & 180 & 180 \\
\hline Num & Sample & VPDB & VSMOW & VPDB \\
\hline 1 & $39107-1 A$ & -8.63 & 14.72 & -15.70 \\
\hline 2 & $39107-2 A$ & -8.77 & 15.44 & -15.00 \\
\hline 3 & $39107-3 A$ & -8.84 & 15.34 & -15.10 \\
\hline 4 & $39107-4 A$ & -8.95 & 15.29 & -15.15 \\
\hline 5 & $39107-5 A$ & -8.93 & 15.66 & -14.78 \\
\hline 6 & $39107-6 A$ & -8.83 & 15.27 & -15.17 \\
\hline 7 & 39107-6A dup & -8.65 & 14.83 & -15.59 \\
\hline 8 & $39107-7 A$ & -8.53 & 15.31 & -15.13 \\
\hline 9 & $39107-8 A$ & -8.67 & 14.40 & -16.01 \\
\hline 10 & $39107-9 A$ & -8.83 & 15.25 & -15.19 \\
\hline 11 & $39107-10 A$ & -8.57 & 15.48 & -14.97 \\
\hline 12 & $39107-11 \mathrm{~A}$ & -8.69 & 15.45 & -14.99 \\
\hline 13 & $39107-12 A$ & -8.76 & 15.61 & -14.84 \\
\hline 14 & $39107-13 A$ & -8.65 & 15.18 & -15.26 \\
\hline 15 & $39107-14 \mathrm{~A}$ & -8.61 & 15.07 & -15.36 \\
\hline 16 & $39107-15 A$ & -8.63 & 15.64 & -14.81 \\
\hline 17 & $39107-16 A$ & -8.72 & 14.14 & -16.26 \\
\hline 18 & 39107-17A & -8.76 & 14.78 & -15.64 \\
\hline 19 & $39107-18 A$ & -8.49 & 15.35 & -15.09 \\
\hline 20 & 39107-19A & -8.79 & 14.90 & -15.53 \\
\hline 21 & $39107-20 A$ & -8.88 & 14.53 & -15.88 \\
\hline 22 & $39107-21 \mathrm{~A}$ & -9.00 & 14.69 & -15.73 \\
\hline 23 & $39107-22 A$ & -8.73 & 16.17 & -14.29 \\
\hline 24 & 39107-22A dup & -8.49 & 15.51 & -14.93 \\
\hline 25 & $39107-23 A$ & -8.92 & 15.19 & -15.25 \\
\hline 26 & $39107-24 A$ & -8.71 & 15.10 & -15.34 \\
\hline 27 & $39107-25 A$ & -8.34 & 14.36 & -16.05 \\
\hline 28 & $39107-26 A$ & -8.52 & 14.57 & -15.84 \\
\hline 29 & $39107-27 A$ & -8.37 & 13.98 & -16.42 \\
\hline 30 & $39107-28 A$ & -7.93 & 15.72 & -14.73 \\
\hline 31 & $39107-29 A$ & -7.98 & 16.39 & -14.08 \\
\hline 32 & $39107-30 A$ & -8.23 & 14.46 & -15.95 \\
\hline 33 & $39107-31 \mathrm{~A}$ & -8.64 & 13.31 & -17.07 \\
\hline 34 & $39107-31 \mathrm{~A}$ & -7.47 & 17.78 & -12.73 \\
\hline 35 & 39107-1TA & -8.72 & 17.54 & -12.97 \\
\hline 36 & 39107-2TA & -8.38 & 15.48 & -14.96 \\
\hline
\end{tabular}




\begin{tabular}{|l|l|l|l|l|}
37 & $39107-3 T A$ & -8.21 & 14.88 & -15.55 \\
\hline 38 & $39107-4 T A$ & -7.85 & 15.29 & -15.14 \\
\hline 39 & $39107-5 T A$ & -8.07 & 14.22 & -16.19 \\
\hline 40 & $39107-6 T A$ & -7.57 & 15.12 & -15.32 \\
\hline 41 & $39107-7 T A$ & -7.58 & 14.72 & -15.71 \\
\hline 42 & $39107-7 T A$ dup & -7.70 & 15.42 & -15.02 \\
\hline 43 & $39107-1 B$ & -9.28 & 13.86 & -16.53 \\
\hline 44 & $39107-1 B$ dup & -9.24 & 14.05 & -16.35 \\
\hline 45 & $39107-1 M$ & -8.30 & 14.42 & -15.99 \\
\hline 46 & $39107-2 M$ & -7.95 & 16.88 & -13.61 \\
\hline 47 & $39107-3 M$ & -9.00 & 16.18 & -14.28 \\
\hline
\end{tabular}

\begin{tabular}{|c|c|c|c|c|}
\hline & & $13 C$ & 180 & 180 \\
\hline Num & Sample & VPDB & VSMOW & VPDB \\
\hline 48 & $39108-1 \mathrm{~A}$ & -8.95 & 13.90 & -16.50 \\
\hline 49 & $39108-2 A$ & -7.88 & 18.69 & -11.85 \\
\hline 50 & $39108-2 A$ & -8.79 & 15.04 & -15.39 \\
\hline 51 & 39108-2A dup & -8.10 & 12.73 & -17.63 \\
\hline 52 & $39108-4 A$ & -8.39 & 15.53 & -14.91 \\
\hline 53 & $39108-5 A$ & -8.38 & 15.04 & -15.39 \\
\hline 54 & 39108-5A dup & -8.20 & 14.41 & -16.01 \\
\hline 55 & $39108-6 A$ & -7.55 & 19.21 & -11.35 \\
\hline 56 & 39108-7A & -7.81 & 17.52 & -12.99 \\
\hline 57 & 39108-7A dup & -7.52 & 17.89 & -12.63 \\
\hline 58 & 39108-8A & -7.83 & 18.53 & -12.00 \\
\hline 59 & $39108-23 A$ & -7.44 & 18.19 & -12.34 \\
\hline 60 & $39108-24 A$ & -7.54 & 18.61 & -11.93 \\
\hline 61 & $39108-25 A$ & -7.32 & 19.23 & -11.32 \\
\hline 62 & 39108-25A dup & -7.22 & 19.19 & -11.36 \\
\hline 63 & $39108-2 M$ & -8.63 & 16.27 & -14.19 \\
\hline 64 & $39108-3 M$ & -8.28 & 15.26 & -15.18 \\
\hline 65 & 39108-1TA & -8.05 & 13.40 & -16.98 \\
\hline 66 & 39108-4TA & -7.66 & 15.30 & -15.14 \\
\hline
\end{tabular}

\begin{tabular}{|c|l|c|c|c|}
\hline \multicolumn{2}{|l|}{} & $13 C$ & 180 & 180 \\
\hline Num & Sample & VPDB & VSMOW & VPDB \\
\hline 67 & $38145-2 \mathrm{~A}$ & -8.26 & 14.36 & -16.05 \\
\hline 68 & $38145-2 \mathrm{~A}$ dup & -8.18 & 14.64 & -15.78 \\
\hline 69 & $38145-3 \mathrm{~A}$ & -8.14 & 14.72 & -15.70 \\
\hline 70 & $38145-4 \mathrm{~A}$ & -8.25 & 14.53 & -15.88 \\
\hline 71 & $38145-5 \mathrm{~A}$ & -8.19 & 14.09 & -16.32 \\
\hline 72 & $38145-6 \mathrm{~A}$ & -8.06 & 14.59 & -15.83 \\
\hline
\end{tabular}




\begin{tabular}{|c|c|c|c|c|}
\hline 73 & $38145-7 A$ & -8.28 & 13.10 & -17.27 \\
\hline 74 & $38145-8 A$ & -8.38 & 13.77 & -16.62 \\
\hline 75 & $38145-9 A$ & -8.25 & 14.06 & -16.34 \\
\hline 76 & $38145-10 A$ & -8.20 & 14.15 & -16.26 \\
\hline 77 & 38145-10A dup & -8.26 & 14.10 & -16.30 \\
\hline 78 & $38145-11 \mathrm{~A}$ & -7.99 & 14.58 & -15.83 \\
\hline 79 & $38145-12 A$ & -7.99 & 15.04 & -15.39 \\
\hline 80 & $38145-13 A$ & -7.96 & 14.25 & -16.16 \\
\hline 81 & $38145-14 A$ & -8.19 & 15.01 & -15.42 \\
\hline 82 & $38145-15 A$ & -8.09 & 14.40 & -16.01 \\
\hline 83 & 38145-15A dup & -8.09 & 13.75 & -16.64 \\
\hline 84 & $38145-16 \mathrm{~A}$ & -8.18 & 13.57 & -16.82 \\
\hline 85 & $38145-17 A$ & -8.03 & 15.55 & -14.90 \\
\hline 86 & $38145-18 A$ & -8.24 & 15.12 & -15.31 \\
\hline 87 & 38145-19A & -8.14 & 13.49 & -16.89 \\
\hline 88 & $38145-20 A$ & -7.95 & 13.32 & -17.05 \\
\hline 89 & $38145-21 \mathrm{~A}$ & -8.24 & 14.19 & -16.21 \\
\hline 90 & $38145-22 A$ & -7.84 & 14.38 & -16.03 \\
\hline 91 & $38145-23 \mathrm{~A}$ & -7.82 & 14.53 & -15.89 \\
\hline 92 & $38145-24 A$ & -7.52 & 15.75 & -14.70 \\
\hline 93 & $38145-25 A$ & -7.61 & 16.22 & -14.25 \\
\hline 94 & $38145-25 \mathrm{~A}$ dup & -7.58 & 16.39 & -14.09 \\
\hline 95 & $38145-26 A$ & -7.84 & 13.01 & -17.36 \\
\hline 96 & $38145-27 A$ & -7.85 & 13.34 & -17.04 \\
\hline 97 & $38145-28 A$ & -7.70 & 14.46 & -15.96 \\
\hline 98 & $38145-1 B$ & -8.77 & 13.90 & -16.49 \\
\hline 99 & $38145-1 M$ & -9.04 & 16.04 & -14.43 \\
\hline 100 & $38145-2 M$ & -8.71 & 16.17 & -14.29 \\
\hline 101 & $38145-3 M$ & -8.30 & 16.53 & -13.95 \\
\hline 102 & $38145-1 T A$ & -7.78 & 15.78 & -14.67 \\
\hline 103 & 38145-2TA rpt & -8.13 & 16.86 & -13.62 \\
\hline 104 & 38145-3TA & -7.75 & 15.95 & -14.51 \\
\hline 105 & 38145-4TA & -7.78 & 13.80 & -16.59 \\
\hline 106 & 38145-4TA dup & -7.71 & 15.75 & -14.70 \\
\hline 107 & 38145-4TArpt & -8.56 & 17.20 & -13.30 \\
\hline 108 & 38145-4TA rpt & -8.19 & 21.11 & -9.50 \\
\hline
\end{tabular}

\begin{tabular}{|c|l|c|c|c|}
\hline Num & Sample & VPDB & VSMOW & VPDB \\
\hline 109 & $38148-1 \mathrm{~A}$ & -8.68 & 18.34 & -12.19 \\
\hline 110 & $38148-1 \mathrm{~A}$ dup & -8.53 & 19.68 & -10.89 \\
\hline 111 & $38148-1 \mathrm{~A}$ rpt & -9.26 & 16.72 & -13.76 \\
\hline 112 & $381482 \mathrm{~A}$ & $-\mathbf{8 . 8 2}$ & 19.41 & -11.15 \\
\hline 113 & $381482 \mathrm{~A}$ dup & -8.29 & 15.83 & -14.63 \\
\hline
\end{tabular}




\begin{tabular}{|c|c|c|c|c|}
\hline 114 & $381482 \mathrm{~A} \mathrm{rpt}$ & -8.23 & 13.38 & -17.00 \\
\hline 115 & $\begin{array}{l}381482 \mathrm{~A} \text { rpt dup (in } 70^{\circ} \mathrm{c} \text { oven } \\
\text { ovenight) }\end{array}$ & -8.16 & 13.00 & -17.37 \\
\hline 116 & $\begin{array}{l}381482 \mathrm{~A} \text { rpt dup (in } 70^{\circ} \mathrm{c} \text { oven } \\
\text { overnight) }\end{array}$ & -8.15 & 13.15 & -17.22 \\
\hline 117 & $38148-3 \mathrm{~A}$ & -8.84 & 17.25 & -13.24 \\
\hline 118 & $38148-4 \mathrm{~A}$ & -8.66 & 18.04 & -12.48 \\
\hline 119 & $38148-5 A$ & -8.57 & 17.22 & -13.28 \\
\hline 120 & $38148-6 \mathrm{~A}$ & -8.45 & 17.43 & -13.07 \\
\hline 121 & 38148-6A dup & -8.44 & 17.53 & -12.97 \\
\hline 122 & $38148-7 A$ & -8.41 & 17.88 & -12.63 \\
\hline 123 & $38148-8 \mathrm{~A}$ & -8.61 & 17.21 & -13.28 \\
\hline 124 & $38148-9 A$ & -8.21 & 17.48 & -13.03 \\
\hline 125 & $38148-10 \mathrm{~A}$ & -8.04 & 18.22 & -12.31 \\
\hline 126 & $38148-11 \mathrm{~A}$ & -8.23 & 18.18 & -12.34 \\
\hline 127 & 38148-11A dup & -8.15 & 18.11 & -12.41 \\
\hline 128 & $38148-12 A$ & -8.38 & 17.75 & -12.76 \\
\hline 129 & $38148-13 A$ & -7.49 & 14.12 & -16.28 \\
\hline 130 & $38148-14 A$ & -7.46 & 14.87 & -15.55 \\
\hline 131 & $38148-15 A$ & -7.31 & 14.52 & -15.90 \\
\hline 132 & $38148-16 A$ & -7.45 & 15.30 & -15.14 \\
\hline 133 & 38148-16A dup & -7.51 & 16.18 & -14.29 \\
\hline 134 & 38148-16A rpt & -8.23 & 18.07 & -12.46 \\
\hline 135 & $38148-17 A$ & -8.37 & 17.22 & -13.27 \\
\hline 136 & 38148-17A dup & -8.32 & 17.67 & -12.84 \\
\hline 137 & $38148-18 \mathrm{~A}$ & -8.14 & 18.34 & -12.19 \\
\hline 138 & $38148-19 A$ & -8.24 & 17.41 & -13.09 \\
\hline 139 & $38148-20 \mathrm{~A}$ & -8.07 & 17.17 & -13.33 \\
\hline 140 & 38148-20A dup & -8.12 & 17.42 & -13.09 \\
\hline 141 & $38148-21 \mathrm{~A}$ & -8.42 & 17.57 & -12.94 \\
\hline 142 & $38148-22 A$ & -8.23 & 17.51 & -12.99 \\
\hline 143 & 38148-22A dup & -8.16 & 17.62 & -12.88 \\
\hline 144 & $38148-23 A$ & -8.24 & 18.38 & -12.16 \\
\hline 145 & $38148-24 A$ & -7.92 & 17.95 & -12.57 \\
\hline 146 & $38148-25 A$ & -7.79 & 17.51 & -13.00 \\
\hline 147 & $38148-1 \mathrm{M}$ & -9.19 & 17.26 & -13.23 \\
\hline 148 & 38148-1M dup & -9.03 & 17.17 & -13.33 \\
\hline 149 & $38148-2 M$ & -8.86 & 16.70 & -13.78 \\
\hline 150 & $38148-3 \mathrm{M}$ & -8.61 & 15.95 & -14.51 \\
\hline 151 & $38148-1 B$ & -9.27 & 16.84 & -13.65 \\
\hline 152 & $38148-2 T A$ & -8.02 & 17.76 & -12.75 \\
\hline
\end{tabular}




\begin{tabular}{|c|l|c|c|c|} 
Num & Sample & VPDB & VSMOW & VPDB \\
\hline 153 & 39149-1A & -8.55 & 21.33 & -9.29 \\
\hline 154 & 39149-1A dup & -8.65 & 18.93 & -11.62 \\
\hline 155 & $39149-6 A$ & -8.24 & 19.77 & -10.81 \\
\hline 156 & $39149-6$ A dup & -8.31 & 18.87 & -11.67 \\
\hline 157 & 39149-7A & -6.73 & 18.76 & -11.78 \\
\hline 158 & 39149-7A dup & -8.33 & 17.22 & -13.27 \\
\hline
\end{tabular}

\begin{tabular}{|c|c|c|c|c|}
\hline & & $13 \mathrm{C}$ & 180 & 180 \\
\hline Num & Sample & VPDB & VSMOW & VPDB \\
\hline 159 & $39151-1 \mathrm{~A}$ & -8.83 & 18.60 & -11.93 \\
\hline 160 & 39151-1A dup & -8.79 & 18.33 & -12.20 \\
\hline 161 & $39151-2 A$ & -8.56 & 19.46 & -11.10 \\
\hline 162 & $39151-3 A$ & -8.64 & 18.86 & -11.68 \\
\hline 163 & $39151-4 A$ & -8.81 & 18.98 & -11.57 \\
\hline 164 & $39151-5 A$ & -8.58 & 19.03 & -11.52 \\
\hline 165 & $39151-6 \mathrm{~A}$ & -8.88 & 19.75 & -10.83 \\
\hline 166 & 39151-6A dup & -8.77 & 20.71 & -9.89 \\
\hline 167 & $39151-7 A$ & -8.57 & 20.15 & -10.43 \\
\hline 168 & $39151-8 \mathrm{~A}$ & -8.65 & 19.67 & -10.90 \\
\hline 169 & $39151-9 A$ & -8.58 & 19.32 & -11.24 \\
\hline 170 & $39151-11 \mathrm{~A}$ & -8.77 & 21.04 & -9.57 \\
\hline 171 & 39151-10A & -8.48 & 19.11 & -11.44 \\
\hline 172 & 39151-10A dup & -8.70 & 18.22 & -12.30 \\
\hline 173 & $39151-12 A$ & -8.82 & 18.81 & -11.74 \\
\hline 174 & 39151-13A & -8.65 & 19.97 & -10.61 \\
\hline 175 & $39151-14 A$ & -8.78 & 18.98 & -11.57 \\
\hline 176 & $39151-16 A$ & -8.72 & 18.76 & -11.78 \\
\hline 177 & $39151-15 \mathrm{~A}$ & -8.49 & 19.67 & -10.90 \\
\hline 178 & 39151-15A dup & -8.55 & 19.60 & -10.96 \\
\hline 179 & 39151-17A & -8.56 & 20.66 & -9.94 \\
\hline 180 & $39151-18 A$ & -8.64 & 19.69 & -10.88 \\
\hline 181 & 39151-19A & -8.64 & 20.06 & -10.52 \\
\hline 182 & $39151-20 \mathrm{~A}$ & -8.61 & 19.03 & -11.52 \\
\hline 183 & $39151-21 \mathrm{~A}$ & -8.75 & 18.93 & -11.61 \\
\hline 184 & $39151-22 A$ & -8.56 & 20.20 & -10.39 \\
\hline 185 & $39151-23 \mathrm{~A}$ & -8.29 & 19.37 & -11.19 \\
\hline 186 & $39151-24 A$ & -8.27 & 20.37 & -10.22 \\
\hline 187 & $39151-25 A$ & -8.37 & 19.48 & -11.09 \\
\hline 188 & $39151-26 \mathrm{~A}$ & -8.43 & 19.72 & -10.85 \\
\hline
\end{tabular}




\section{Appendix 2: Collagen Stable Isotope Data}

Individual samples represented by their CMN number (i.e. 39***). Samples with $A$ indicate powder collected along the length of the antler, $B$ indicate samples collected along the mandible, $M$ indicate samples taken long the third molar, and finally TA indicate samples collected on the tine of the antler.

\begin{tabular}{|c|c|c|c|c|c|}
\hline Num & Sample & $\boldsymbol{\delta}^{\mathbf{1 3}} \mathbf{C}$ (VPDB) & $\mathbf{C} \%$ & $\boldsymbol{\delta}^{\mathbf{1 5}} \mathbf{N}$ (AIR) & $\mathbf{N} \%$ \\
\hline 189 & $39079-1 \mathrm{~A}$ & $\mathbf{- 1 8 . 9 0}$ & 30.23 & $\mathbf{4 . 9 0}$ & 10.61 \\
\hline 190 & $39079-2 \mathrm{~A}$ & $\mathbf{- 1 8 . 9 7}$ & 43.45 & $\mathbf{5 . 5 2}$ & 15.73 \\
\hline 191 & $39079-3 \mathrm{~A}$ & $\mathbf{- 1 8 . 9 1}$ & 40.22 & $\mathbf{5 . 5 3}$ & 14.43 \\
\hline 192 & $39079-4 \mathrm{~A}$ & $\mathbf{- 1 8 . 9 8}$ & 44.46 & $\mathbf{5 . 6 8}$ & 16.06 \\
\hline 193 & $39079-5 \mathrm{~A}$ & $\mathbf{- 1 9 . 0 5}$ & 39.56 & $\mathbf{5 . 3 0}$ & 14.27 \\
\hline 194 & $39079-6 \mathrm{~A}$ & $\mathbf{- 1 8 . 9 3}$ & 43.64 & $\mathbf{5 . 6 7}$ & 15.79 \\
\hline 195 & $39079-7 \mathrm{~A}$ & $\mathbf{- 1 8 . 8 2}$ & 37.40 & $\mathbf{5 . 5 7}$ & 13.32 \\
\hline 196 & $39079-7 \mathrm{~A}$ dup & $\mathbf{- 1 8 . 8 4}$ & 37.55 & $\mathbf{5 . 6 5}$ & 13.42 \\
\hline 197 & $39079-8 \mathrm{~A}$ & $\mathbf{- 1 8 . 8 3}$ & 35.67 & $\mathbf{5 . 5 7}$ & 12.65 \\
\hline 198 & $39079-9 \mathrm{~A}$ & $\mathbf{- 1 8 . 8 3}$ & 41.90 & $\mathbf{5 . 8 8}$ & 14.99 \\
\hline 199 & $39079-10 \mathrm{~A}$ & $\mathbf{- 1 8 . 4 9}$ & 32.19 & $\mathbf{5 . 7 2}$ & 11.12 \\
\hline 200 & $39079-11 \mathrm{~A}$ & $\mathbf{- 1 8 . 7 5}$ & 36.36 & $\mathbf{5 . 7 9}$ & 12.76 \\
\hline 201 & $39079-12 \mathrm{~A}$ & $\mathbf{- 1 8 . 9 0}$ & 36.06 & $\mathbf{5 . 7 1}$ & 12.70 \\
\hline 202 & $39079-13 \mathrm{~A}$ & $\mathbf{- 1 8 . 7 3}$ & 26.60 & $\mathbf{5 . 3 7}$ & 8.99 \\
\hline 203 & $39079-14 \mathrm{~A}$ & $\mathbf{- 1 8 . 9 7}$ & 36.53 & $\mathbf{5 . 9 1}$ & 12.74 \\
\hline 204 & $39079-15 \mathrm{~A}$ & $\mathbf{- 1 9 . 0 1}$ & 41.15 & $\mathbf{5 . 9 7}$ & 14.55 \\
\hline 205 & $39079-15 \mathrm{~A}$ dup & $\mathbf{- 1 8 . 9 1}$ & 33.45 & $\mathbf{5 . 7 4}$ & 11.52 \\
\hline 206 & $39079-16 \mathrm{~A}$ & $\mathbf{- 1 8 . 8 3}$ & 37.65 & $\mathbf{5 . 8 4}$ & 13.18 \\
\hline 207 & $39079-17 \mathrm{~A}$ & $\mathbf{- 1 9 . 0 2}$ & 44.58 & $\mathbf{6 . 0 1}$ & 15.55 \\
\hline 208 & $39079-18 \mathrm{~A}$ & $\mathbf{- 1 8 . 9 4}$ & 38.93 & $\mathbf{5 . 8 6}$ & 13.26 \\
\hline 209 & $39079-19 \mathrm{~A}$ & $\mathbf{- 1 8 . 8 6}$ & 35.02 & $\mathbf{5 . 6 5}$ & 11.63 \\
\hline 210 & $39079-1 T A$ & $\mathbf{- 1 9 . 1 9}$ & 41.40 & $\mathbf{5 . 6 2}$ & 14.63 \\
\hline 211 & $39079-2 \mathrm{~A} \mathrm{~A}$ & $\mathbf{- 1 8 . 9 3}$ & 37.58 & $\mathbf{5 . 8 2}$ & 13.20 \\
\hline 212 & $39079-1 \mathrm{~B}$ & $\mathbf{- 1 8 . 5 2}$ & 22.88 & $\mathbf{3 . 3 0}$ & 7.57 \\
\hline & & & & & \\
\hline
\end{tabular}

\begin{tabular}{|c|c|c|c|c|c|}
\hline Num & Sample & $\boldsymbol{\delta}^{\mathbf{1 5}} \mathbf{N}$ (AIR) & $\mathbf{N \%}$ & $\boldsymbol{\delta}^{\mathbf{1 3}} \mathbf{C}$ (VPDB) & $\mathbf{C} \%$ \\
\hline 214 & $39090-1 \mathrm{~A}$ & $\mathbf{5 . 2 8}$ & 16.05 & $\mathbf{- 1 8 . 4 0}$ & 44.16 \\
\hline 215 & $39090-2 \mathrm{~A}$ & $\mathbf{5 . 4 3}$ & 16.08 & $\mathbf{- 1 8 . 4 1}$ & 44.39 \\
\hline 216 & $39090-3 \mathrm{~A}$ & $\mathbf{5 . 8 5}$ & 14.76 & $\mathbf{- 1 8 . 3 7}$ & 40.90 \\
\hline 217 & $39090-4 \mathrm{~A}$ & $\mathbf{6 . 0 5}$ & 15.35 & $\mathbf{- 1 8 . 3 7}$ & 42.15 \\
\hline 218 & $39090-5 \mathrm{~A}$ & $\mathbf{5 . 8 0}$ & 15.69 & $\mathbf{- 1 8 . 3 4}$ & 43.00 \\
\hline 219 & $39090-6 \mathrm{~A}$ & $\mathbf{5 . 5 3}$ & 15.78 & $\mathbf{- 1 8 . 3 7}$ & 42.87 \\
\hline 220 & $39090-7 \mathrm{~A}$ & $\mathbf{5 . 6 0}$ & 15.84 & $\mathbf{- 1 8 . 4 1}$ & 43.19 \\
\hline 221 & $39090-8 \mathrm{~A}$ & $\mathbf{6 . 2 6}$ & 14.81 & $\mathbf{- 1 8 . 3 7}$ & 40.79 \\
\hline 222 & $39090-9 \mathrm{~A}$ & $\mathbf{6 . 5 6}$ & 15.82 & $\mathbf{- 1 8 . 4 1}$ & 43.32 \\
\hline 223 & $39090-10 \mathrm{~A}$ & $\mathbf{6 . 3 1}$ & 15.59 & $\mathbf{- 1 8 . 3 8}$ & 42.83 \\
\hline 224 & $39090-10 \mathrm{~A}$ dup & $\mathbf{6 . 3 1}$ & 15.50 & $\mathbf{- 1 8 . 3 7}$ & 42.55 \\
\hline
\end{tabular}




\begin{tabular}{|l|c|l|l|l|l|}
\hline 225 & $39090-11 \mathrm{~A}$ & $\mathbf{6 . 1 1}$ & 13.50 & $\mathbf{- 1 8 . 3 8}$ & 37.58 \\
\hline 226 & $39090-12 \mathrm{~A}$ & $\mathbf{6 . 0 4}$ & 13.44 & $\mathbf{- 1 8 . 4 2}$ & 37.21 \\
\hline 227 & $39090-13 \mathrm{~A}$ & $\mathbf{6 . 0 6}$ & 15.46 & $\mathbf{- 1 8 . 5 0}$ & 42.80 \\
\hline 228 & $39090-14 \mathrm{~A}$ & $\mathbf{5 . 9 3}$ & 12.76 & $\mathbf{- 1 8 . 3 7}$ & 35.25 \\
\hline 229 & $39090-15 \mathrm{~A}$ & $\mathbf{6 . 2 5}$ & 15.56 & $\mathbf{- 1 8 . 5 3}$ & 42.82 \\
\hline 230 & $39090-16 \mathrm{~A}$ & $\mathbf{6 . 1 8}$ & 15.82 & $\mathbf{- 1 8 . 5 3}$ & 43.60 \\
\hline 231 & $39090-17 \mathrm{~A}$ & $\mathbf{6 . 2 9}$ & 16.08 & $\mathbf{- 1 8 . 5 1}$ & 44.15 \\
\hline 232 & $39090-18 \mathrm{~A}$ & $\mathbf{6 . 5 1}$ & 15.11 & $\mathbf{- 1 8 . 5 4}$ & 42.10 \\
\hline 233 & $39090-18 \mathrm{~A}$ dup & $\mathbf{6 . 4 7}$ & 15.04 & $\mathbf{- 1 8 . 6 0}$ & 42.07 \\
\hline 234 & $39090-19 \mathrm{~A}$ & $\mathbf{6 . 4 3}$ & 15.97 & $\mathbf{- 1 8 . 5 3}$ & 44.16 \\
\hline 235 & $39090-20 \mathrm{~A}$ & $\mathbf{6 . 3 6}$ & 15.75 & $\mathbf{- 1 8 . 5 0}$ & 43.38 \\
\hline 236 & $39090-21 \mathrm{~A}$ & $\mathbf{6 . 7 1}$ & 15.58 & $\mathbf{- 1 8 . 5 7}$ & 42.98 \\
\hline 237 & $39090-22 \mathrm{~A}$ & $\mathbf{6 . 6 2}$ & 15.46 & $\mathbf{- 1 8 . 5 7}$ & 42.57 \\
\hline 238 & $39090-22 \mathrm{~A}$ dup & $\mathbf{6 . 6 1}$ & 15.48 & $\mathbf{- 1 8 . 6 0}$ & 42.79 \\
\hline 239 & $39090-23 \mathrm{~A}$ & $\mathbf{6 . 8 2}$ & 16.20 & $\mathbf{- 1 8 . 6 9}$ & 45.13 \\
\hline 240 & $39090-24 \mathrm{~A}$ & $\mathbf{6 . 8 6}$ & 15.83 & $\mathbf{- 1 8 . 6 1}$ & 44.00 \\
\hline 241 & $39090-25 \mathrm{~A}$ & $\mathbf{6 . 9 2}$ & 15.83 & $\mathbf{- 1 8 . 6 0}$ & 44.32 \\
\hline 242 & $39090-26 \mathrm{~A}$ & $\mathbf{6 . 9 1}$ & 16.08 & $\mathbf{- 1 8 . 7 1}$ & 45.19 \\
\hline 243 & $39090-1 T A$ & $\mathbf{5 . 5 6}$ & 15.82 & $\mathbf{- 1 8 . 4 1}$ & 43.24 \\
\hline 244 & $39090-2 T A$ & $\mathbf{5 . 7 0}$ & 15.75 & $\mathbf{- 1 8 . 3 6}$ & 43.23 \\
\hline 245 & $39090-3 T A$ & $\mathbf{6 . 7 8}$ & 15.73 & $\mathbf{- 1 8 . 5 3}$ & 43.44 \\
\hline 246 & $39090-1 \mathrm{~A}$ & $\mathbf{4 . 2 7}$ & 15.23 & $\mathbf{- 1 8 . 8 2}$ & 43.52 \\
\hline
\end{tabular}

\begin{tabular}{|c|c|c|c|c|c|}
\hline Num & Sample & $\boldsymbol{\delta}^{\mathbf{1 3}} \mathbf{C}$ (VPDB) & $\mathbf{C} \%$ & $\boldsymbol{\delta}^{\mathbf{1 5}} \mathbf{N}(\mathbf{A I R})$ & $\mathbf{N} \%$ \\
\hline 247 & $39102-1 \mathrm{~A}$ & $\mathbf{- 1 9 . 1 2}$ & 31.89 & $\mathbf{4 . 1 9}$ & 10.99 \\
\hline 248 & $39102-1 \mathrm{~A} d u p$ & $\mathbf{- 1 8 . 9 7}$ & 24.33 & $\mathbf{3 . 7 9}$ & 8.20 \\
\hline 249 & $39102-2 \mathrm{~A}$ & $\mathbf{- 1 8 . 9 8}$ & 44.72 & $\mathbf{4 . 3 6}$ & 16.29 \\
\hline 250 & $39102-3 \mathrm{~A}$ & $\mathbf{- 1 9 . 0 5}$ & 44.81 & $\mathbf{4 . 7 3}$ & 16.29 \\
\hline 251 & $39102-4 \mathrm{~A}$ & $\mathbf{- 1 8 . 9 7}$ & 44.15 & $\mathbf{4 . 8 3}$ & 16.10 \\
\hline 252 & $39102-5 \mathrm{~A}$ & $\mathbf{- 1 8 . 9 0}$ & 44.32 & $\mathbf{4 . 8 2}$ & 16.23 \\
\hline 253 & $39102-6 \mathrm{~A}$ & $\mathbf{- 1 8 . 4 9}$ & 20.26 & $\mathbf{4 . 1 3}$ & 6.99 \\
\hline 254 & $39102-7 \mathrm{~A}$ & $\mathbf{- 1 8 . 8 2}$ & 44.33 & $\mathbf{5 . 2 0}$ & 16.22 \\
\hline 255 & $39102-8 \mathrm{~A}$ & $\mathbf{- 1 8 . 6 7}$ & 37.13 & $\mathbf{5 . 2 9}$ & 13.29 \\
\hline 256 & $39102-9 \mathrm{~A}$ & $\mathbf{- 1 8 . 8 1}$ & 44.55 & $\mathbf{5 . 2 7}$ & 16.17 \\
\hline 257 & $39102-10 \mathrm{~A}$ & $\mathbf{- 1 8 . 8 8}$ & 45.24 & $\mathbf{5 . 1 9}$ & 16.43 \\
\hline 258 & $39102-11 \mathrm{~A}$ & $\mathbf{- 1 8 . 8 7}$ & 42.48 & $\mathbf{5 . 0 1}$ & 17.50 \\
\hline 259 & $39102-12 \mathrm{~A}$ & $\mathbf{- 1 8 . 8 7}$ & 39.43 & $\mathbf{5 . 1 6}$ & 16.08 \\
\hline 260 & $39102-13 \mathrm{~A}$ & $\mathbf{- 1 8 . 8 7}$ & 43.94 & $\mathbf{5 . 2 3}$ & 18.15 \\
\hline 261 & $39102-13 \mathrm{~A} d \mathrm{dup}$ & $\mathbf{- 1 8 . 9 4}$ & 43.82 & $\mathbf{5 . 0 3}$ & 18.04 \\
\hline 262 & $39102-14 \mathrm{~A}$ & $\mathbf{- 1 8 . 9 1}$ & 43.84 & $\mathbf{5 . 2 6}$ & 18.14 \\
\hline 263 & $39102-15 \mathrm{~A}$ & $\mathbf{- 1 8 . 9 4}$ & 44.18 & $\mathbf{5 . 2 5}$ & 18.26 \\
\hline 264 & $39102-16 \mathrm{~A}$ & $\mathbf{- 1 9 . 0 0}$ & 40.48 & $\mathbf{5 . 2 1}$ & 16.49 \\
\hline 265 & $39102-17 \mathrm{~A}$ & $\mathbf{- 1 8 . 9 6}$ & 39.68 & $\mathbf{5 . 2 9}$ & 16.06 \\
\hline 266 & $39102-18 \mathrm{~A}$ & $\mathbf{- 1 9 . 0 4}$ & 44.01 & $\mathbf{5 . 3 5}$ & 18.05 \\
\hline
\end{tabular}




\begin{tabular}{|l|c|c|c|c|c|}
\hline 267 & $39102-19 A$ & $\mathbf{- 1 8 . 8 4}$ & 33.48 & $\mathbf{5 . 0 6}$ & 13.30 \\
\hline 268 & $39102-20 \mathrm{~A}$ & $\mathbf{- 1 8 . 9 1}$ & 32.08 & $\mathbf{4 . 8 8}$ & 12.62 \\
\hline 269 & $39102-20 \mathrm{~A}$ dup & $\mathbf{- 1 8 . 8 9}$ & 31.57 & $\mathbf{5 . 0 1}$ & 12.47 \\
\hline 270 & $39102-21 \mathrm{~A}$ & $\mathbf{- 1 8 . 9 6}$ & 42.49 & $\mathbf{5 . 3 9}$ & 17.02 \\
\hline 271 & $39102-22 \mathrm{~A}$ & $\mathbf{- 1 8 . 6 6}$ & 39.73 & $\mathbf{5 . 2 9}$ & 15.74 \\
\hline 272 & $39102-1 \mathrm{TA}$ & $\mathbf{- 1 9 . 0 3}$ & 31.95 & $\mathbf{4 . 4 4}$ & 12.55 \\
\hline 273 & $39102-2 \mathrm{TA}$ & $\mathbf{- 1 8 . 9 1}$ & 34.55 & $\mathbf{4 . 7 5}$ & 13.81 \\
\hline 274 & $39102-3 T A$ & $\mathbf{- 1 8 . 7 0}$ & 42.96 & $\mathbf{5 . 4 6}$ & 17.27 \\
\hline 275 & $39102-1 \mathrm{~B}$ & $\mathbf{- 1 9 . 2 1}$ & 16.12 & $\mathbf{2 . 2 9}$ & 5.31 \\
\hline
\end{tabular}

\begin{tabular}{|c|c|c|c|c|c|}
\hline Num & Sample & $\delta^{15} N(A I R)$ & N\% & $\delta^{13} \mathrm{C}$ (VPDB) & $\mathrm{C} \%$ \\
\hline 276 & $39107-1 \mathrm{~A}$ & 2.99 & 12.94 & -19.47 & 35.07 \\
\hline 277 & $39107-2 A$ & 2.79 & 11.89 & -19.29 & 32.33 \\
\hline 278 & $39107-3 A$ & 2.94 & 13.18 & -19.44 & 34.99 \\
\hline 279 & 39107-3A dup & 2.76 & 11.08 & -19.38 & 32.24 \\
\hline 280 & $39107-4 \mathrm{~A}$ & 3.33 & 16.80 & -19.35 & 43.05 \\
\hline 281 & $39107-5 A$ & 3.48 & 16.99 & -19.43 & 44.01 \\
\hline 282 & $39107-6 A$ & 3.28 & 15.88 & -19.43 & 41.06 \\
\hline 283 & 39107-7A & 2.59 & 11.34 & -19.19 & 33.14 \\
\hline 284 & $39107-8 A$ & 2.94 & 15.14 & -19.43 & 42.61 \\
\hline 285 & $39107-9 A$ & 2.37 & 9.84 & -19.28 & 28.96 \\
\hline 286 & $39107-10 A$ & 2.94 & 15.97 & -19.46 & 44.89 \\
\hline 287 & $39107-11 \mathrm{~A}$ & 2.81 & 14.47 & -19.38 & 40.98 \\
\hline 288 & $39107-12 A$ & 2.76 & 9.08 & -19.11 & 26.79 \\
\hline 289 & $39107-13 A$ & 2.94 & 16.10 & -19.43 & 45.30 \\
\hline 290 & $39107-14 A$ & 3.06 & 16.02 & -19.43 & 45.15 \\
\hline 291 & $39107-15 A$ & 3.10 & 16.11 & -19.41 & 45.15 \\
\hline 292 & $39107-16 A$ & 3.02 & 16.12 & -19.51 & 44.93 \\
\hline 293 & $39107-17 A$ & 3.21 & 16.16 & -19.44 & 45.02 \\
\hline 294 & $39107-18 A$ & 2.94 & 13.64 & -19.61 & 39.99 \\
\hline 295 & 39107-18A dup & 3.13 & 13.78 & -19.43 & 39.13 \\
\hline 296 & 39107-19A & 2.97 & 13.61 & -19.61 & 39.38 \\
\hline 297 & $39107-20 A$ & 3.13 & 16.07 & -19.52 & 44.54 \\
\hline 298 & $39107-21 \mathrm{~A}$ & 3.36 & 16.27 & -19.55 & 45.01 \\
\hline 299 & $39107-22 A$ & 3.34 & 16.12 & -19.53 & 44.68 \\
\hline 300 & $39107-23 A$ & 3.14 & 13.42 & -19.54 & 38.05 \\
\hline 301 & $39107-24 A$ & 3.25 & 13.71 & -19.60 & 39.06 \\
\hline 302 & $39107-25 A$ & 3.40 & 10.79 & -19.45 & 31.43 \\
\hline 303 & $39107-26 A$ & 3.86 & 15.77 & -19.52 & 43.98 \\
\hline 304 & $39107-27 A$ & 4.11 & 16.18 & -19.45 & 45.36 \\
\hline 305 & 39107-27A dup & 3.93 & 15.95 & -19.44 & 44.36 \\
\hline 306 & $39107-28 A$ & 4.08 & 15.64 & -19.42 & 43.96 \\
\hline 307 & $39107-29 A$ & 3.57 & 11.16 & -19.25 & 33.06 \\
\hline 308 & $39107-30 A$ & 4.44 & 15.84 & -19.41 & 44.18 \\
\hline
\end{tabular}




\begin{tabular}{|l|l|l|l|l|l|}
\hline 309 & $39107-31 A$ & $\mathbf{4 . 5 5}$ & 14.02 & $\mathbf{- 1 9 . 1 3}$ & 40.02 \\
\hline 310 & $39107-1 T A$ & $\mathbf{2 . 8 4}$ & 13.23 & $\mathbf{- 1 9 . 7 3}$ & 37.82 \\
\hline 311 & $39107-2 T A$ & $\mathbf{2 . 7 7}$ & 11.50 & $\mathbf{- 1 9 . 3 1}$ & 32.78 \\
\hline 312 & $39107-3 T A$ & $\mathbf{3 . 9 7}$ & 16.03 & $\mathbf{- 1 9 . 3 4}$ & 43.92 \\
\hline 313 & $39107-4 T A$ & 4.20 & 16.03 & $\mathbf{- 1 9 . 0 2}$ & 44.07 \\
\hline 314 & $39107-5 T A$ & $\mathbf{3 . 6 5}$ & 10.67 & $\mathbf{- 1 9 . 0 2}$ & 31.08 \\
\hline 315 & 39107-5TA dup & $\mathbf{4 . 0 1}$ & 11.99 & $\mathbf{- 1 9 . 0 7}$ & 33.45 \\
\hline 316 & 39107-6TA & $\mathbf{4 . 2 3}$ & 12.80 & $\mathbf{- 1 8 . 9 6}$ & 36.44 \\
\hline 317 & $39107-7 T A$ & $\mathbf{4 . 1 7}$ & 12.63 & $\mathbf{- 1 8 . 9 9}$ & 35.69 \\
\hline 318 & $39107-1 B$ & $\mathbf{2 . 6 7}$ & 14.72 & $\mathbf{- 1 9 . 2 8}$ & 42.75 \\
\hline
\end{tabular}

\begin{tabular}{|c|c|c|c|c|c|}
\hline Num & Sample & $\begin{array}{c}\delta 13 C \\
\text { (VPDB) }\end{array}$ & $\mathrm{C} \%$ & $\delta 15 N(A I R)$ & N\% \\
\hline 319 & $39108-1 \mathrm{~A}$ & -18.87 & 34.02 & 5.59 & 11.83 \\
\hline 320 & 39108-1A dup & -18.79 & 28.90 & 5.41 & 10.11 \\
\hline 321 & $39108-2 \mathrm{~A}$ & -18.49 & 20.45 & 5.35 & 6.72 \\
\hline 322 & 39108--2A RPT & -18.90 & 38.21 & 6.11 & 13.54 \\
\hline 323 & $39108-3 A$ & -18.61 & 25.11 & 5.24 & 8.64 \\
\hline 324 & $39108-4 \mathrm{~A}$ & -18.53 & 25.59 & 5.79 & 8.90 \\
\hline 325 & $39108-5 A$ & -18.75 & 44.38 & 6.65 & 16.01 \\
\hline 326 & $39108-6 A$ & -18.71 & 39.14 & 6.35 & 14.01 \\
\hline 327 & 39108-7A & -18.64 & 30.87 & 5.99 & 10.77 \\
\hline 328 & $39108-8 \mathrm{~A}$ & -18.77 & 40.64 & 6.28 & 14.60 \\
\hline 329 & $39108-9 A$ & -18.85 & 39.88 & 6.08 & 14.20 \\
\hline 330 & $39108-10 A$ & -18.63 & 25.87 & 5.14 & 8.64 \\
\hline 331 & $39108-11 \mathrm{~A}$ & -18.50 & 20.59 & 5.72 & 6.84 \\
\hline 332 & 39108--11A RPT & -18.81 & 33.95 & 6.00 & 11.96 \\
\hline 333 & $39108-12 A$ & -18.85 & 33.36 & 5.89 & 11.54 \\
\hline 334 & 39108-12A dup & -18.63 & 26.24 & 5.72 & 8.99 \\
\hline 335 & 39108-13A & -18.50 & 25.57 & 5.69 & 8.73 \\
\hline 336 & $39108-14 A$ & -18.28 & 16.72 & 5.42 & 5.22 \\
\hline 337 & 39108-14A RPT dup & -18.73 & 32.03 & 6.20 & 11.09 \\
\hline 338 & 39108--14A RPT & -18.61 & 27.56 & 6.15 & 9.49 \\
\hline 339 & $39108-15 A$ & -18.66 & 44.66 & 6.52 & 16.11 \\
\hline 340 & $39108-16 A$ & -18.86 & 44.24 & 6.49 & 16.07 \\
\hline 341 & $39108-17 A$ & -18.58 & 31.65 & 6.13 & 10.98 \\
\hline 342 & $39108-18 A$ & -18.88 & 33.68 & 6.20 & 11.85 \\
\hline 343 & $39108-19 A$ & -18.86 & 34.36 & 6.46 & 12.07 \\
\hline 344 & $39108-20 A$ & -18.87 & 39.64 & 6.50 & 14.03 \\
\hline 345 & $39108-21 \mathrm{~A}$ & -18.79 & 34.63 & 6.39 & 12.26 \\
\hline 346 & 39108-21A dup & -18.52 & 22.98 & 5.58 & 7.84 \\
\hline 347 & 39108--21A RPT & -18.72 & 28.10 & 6.17 & 9.62 \\
\hline 348 & $39108-22 A$ & -18.90 & 41.06 & 6.64 & 14.73 \\
\hline 349 & $39108-23 A$ & -18.58 & 29.66 & 6.09 & 10.16 \\
\hline
\end{tabular}




\begin{tabular}{|l|l|l|l|l|l|}
\hline 350 & $39108-24 A$ & $\mathbf{- 1 8 . 6 5}$ & 35.53 & $\mathbf{6 . 0 1}$ & 12.32 \\
\hline 351 & $39108-25 A$ & $\mathbf{- 1 8 . 4 5}$ & 39.72 & $\mathbf{6 . 2 7}$ & 13.98 \\
\hline 352 & $39108-1 T A$ & $\mathbf{- 1 9 . 0 7}$ & 30.26 & $\mathbf{5 . 4 8}$ & 10.45 \\
\hline 353 & $39108-2 T A$ & $\mathbf{- 1 8 . 9 1}$ & 34.75 & $\mathbf{5 . 6 8}$ & 12.53 \\
\hline 354 & $39108-3 T A$ & $\mathbf{- 1 8 . 9 2}$ & 39.03 & $\mathbf{6 . 7 0}$ & 14.16 \\
\hline 355 & $39108-4 T A$ & $\mathbf{- 1 8 . 1 6}$ & 34.86 & $\mathbf{6 . 2 7}$ & 12.60 \\
\hline 356 & $39108-1 B$ & $\mathbf{- 2 0 . 4 7}$ & 17.99 & $\mathbf{3 . 6 2}$ & 4.93 \\
\hline 357 & $39108-1 B$ dup & $\mathbf{- 1 9 . 0 1}$ & 17.66 & $\mathbf{3 . 7 0}$ & 5.48 \\
\hline 358 & $39108--1 B$ RPT & $\mathbf{- 1 9 . 0 2}$ & 16.63 & $\mathbf{3 . 1 8}$ & 4.96 \\
\hline
\end{tabular}

\begin{tabular}{|c|c|c|c|c|c|}
\hline Num & Sample & $\delta^{15} N(A I R)$ & N\% & $\delta^{13} C$ (VPDB) & $\mathrm{C} \%$ \\
\hline 359 & $39110-1 A$ & 3.44 & 12.05 & -19.47 & 35.53 \\
\hline 360 & $39110-2 A$ & 4.73 & 15.12 & -19.23 & 43.75 \\
\hline 361 & $39110-3 A$ & 4.61 & 11.30 & -18.93 & 32.96 \\
\hline 362 & 39110-3A dup & 3.67 & 5.29 & -18.49 & 16.55 \\
\hline 363 & 39110-4A & 4.84 & 12.15 & -18.98 & 35.41 \\
\hline 364 & $39110-5 A$ & 5.32 & 13.55 & -18.87 & 39.13 \\
\hline 365 & $39110-6 \mathrm{~A}$ & 5.63 & 15.25 & -18.88 & 43.84 \\
\hline 366 & $39110-7 A$ & 4.50 & 11.51 & -19.00 & 33.99 \\
\hline 367 & $39110-8 A$ & 4.80 & 15.19 & -19.19 & 43.79 \\
\hline 368 & $39110-9 A$ & 5.01 & 15.35 & -19.21 & 43.97 \\
\hline 369 & $39110-10 A$ & 4.94 & 15.40 & -19.14 & 44.18 \\
\hline 370 & $39110-11 \mathrm{~A}$ & 5.89 & 15.16 & -18.91 & 43.74 \\
\hline 371 & $39110-12 A$ & 5.56 & 9.97 & -18.63 & 29.52 \\
\hline 372 & $39110-13 A$ & 6.17 & 15.19 & -18.74 & 43.69 \\
\hline 373 & $39110-14 A$ & 5.95 & 15.95 & -18.83 & 44.22 \\
\hline 374 & 39110-15A & 5.80 & 15.88 & -18.95 & 44.00 \\
\hline 375 & $39110-16 A$ & 5.13 & 12.01 & -19.08 & 33.96 \\
\hline 376 & 39110-17A & 2.53 & 14.01 & -18.78 & 39.61 \\
\hline 377 & $39110-18 A$ & 5.36 & 15.74 & -19.23 & 43.93 \\
\hline 378 & 39110-19A & 5.02 & 14.66 & -19.34 & 41.32 \\
\hline 379 & $39110-20 A$ & 5.31 & 16.30 & -19.12 & 45.15 \\
\hline 380 & 39110-20A dup & 5.28 & 14.40 & -19.19 & 40.35 \\
\hline 381 & $39110-21 \mathrm{~A}$ & 5.19 & 15.97 & -19.19 & 44.31 \\
\hline 382 & $39110-22 A$ & 5.12 & 12.50 & -18.95 & 35.32 \\
\hline 383 & $39110-23 A$ & 5.93 & 15.85 & -18.87 & 43.94 \\
\hline 384 & $39110-24 A$ & 6.14 & 14.20 & -18.69 & 39.75 \\
\hline 385 & $39110-25 A$ & 6.13 & 15.99 & -18.78 & $44.4 \varepsilon$ \\
\hline 386 & $39110-26 \mathrm{~A}$ & 6.29 & 15.92 & -18.73 & 44.35 \\
\hline 387 & $39110-27 A$ & 6.12 & 10.22 & -18.37 & 29.48 \\
\hline 388 & 39110-27A dup & 6.09 & 9.90 & -18.34 & 28.69 \\
\hline 389 & $39110-28 \mathrm{~A}$ & 6.27 & 11.16 & -18.40 & 31.84 \\
\hline 390 & $39110-29 A$ & 6.77 & 14.54 & -18.33 & 41.16 \\
\hline 391 & 39110-1TA & 3.85 & 13.14 & -19.33 & 36.52 \\
\hline 392 & 39110-2TA & 6.27 & 11.62 & -18.43 & 33.09 \\
\hline 393 & 39110-1B & 3.53 & 8.09 & -18.96 & 23.95 \\
\hline
\end{tabular}




\begin{tabular}{|c|c|c|c|c|c|}
\hline Num & Sample & $\delta^{15} \mathrm{~N}(\mathrm{AIR})$ & N\% & $\delta^{13} \mathrm{C}$ (VPDB) & $\mathrm{C} \%$ \\
\hline 394 & $39120-1 A$ & 4.54 & 5.14 & -18.33 & 17.40 \\
\hline 395 & $39120-2 A$ & 5.65 & 15.26 & -18.71 & 44.26 \\
\hline 396 & $39120-3 A$ & 5.34 & 10.63 & -18.66 & 32.07 \\
\hline 397 & $39120-4 A$ & 5.54 & 12.92 & -18.67 & 38.43 \\
\hline 398 & $39120-5 A$ & 5.55 & 15.37 & -18.78 & 44.75 \\
\hline 399 & $39120-6 A$ & 5.81 & 14.52 & -18.63 & 42.83 \\
\hline 400 & 39120-7A & 5.63 & 11.82 & -18.54 & 35.36 \\
\hline 401 & 39120-7A dup & 5.13 & 7.42 & -18.29 & 23.11 \\
\hline 402 & $39120-8 \mathrm{~A}$ & 5.90 & 15.32 & -18.59 & 45.16 \\
\hline 403 & 39120-9A & 5.67 & 11.82 & -18.61 & 35.61 \\
\hline 404 & $39120-10 A$ & 5.14 & 7.46 & -18.35 & 23.30 \\
\hline 405 & $39120-11 \mathrm{~A}$ & 5.84 & 12.41 & -18.75 & 37.46 \\
\hline 406 & $39120-12 A$ & 5.68 & 11.23 & -18.71 & 33.78 \\
\hline 407 & $39120-13 \mathrm{~A}$ & 5.71 & 12.44 & -18.93 & 37.29 \\
\hline 408 & $39120-14 A$ & 5.89 & 13.39 & -18.88 & 40.12 \\
\hline 409 & $39120-15 A$ & 5.73 & 11.77 & -18.76 & 35.40 \\
\hline 410 & $39120-16 A$ & 5.85 & 14.50 & -18.70 & 43.00 \\
\hline 411 & $39120-17 A$ & 5.54 & 11.82 & -18.92 & 37.04 \\
\hline 412 & 39120-1TA & 5.89 & 14.37 & -18.94 & 42.60 \\
\hline 413 & 39120-2TA & 5.93 & 15.15 & -18.84 & 44.56 \\
\hline 414 & $39120-1 B$ & 7.00 & 14.34 & -18.99 & 43.79 \\
\hline
\end{tabular}

\begin{tabular}{|c|c|c|c|c|c|}
\hline Num & Sample & $\boldsymbol{\delta}^{\mathbf{1 5}} \mathbf{N}(\mathbf{A I R})$ & $\mathbf{N} \%$ & $\boldsymbol{\delta}^{\mathbf{1 3}} \mathbf{C}$ (VPDB) & $\mathbf{C} \%$ \\
\hline 415 & $39132-1 \mathrm{~A}$ & $\mathbf{- 1 9 . 3 9}$ & $\mathbf{2 8 . 3 3}$ & $\mathbf{4 . 6 0}$ & 10.80 \\
\hline 416 & $39132-2 \mathrm{~A}$ & $\mathbf{- 1 9 . 2 9}$ & 44.00 & $\mathbf{4 . 6 5}$ & 18.19 \\
\hline 417 & $39132-3 \mathrm{~A}$ & $\mathbf{- 1 9 . 2 8}$ & 42.92 & $\mathbf{5 . 1 5}$ & 17.48 \\
\hline 418 & $39132-4 \mathrm{~A}$ & $\mathbf{- 1 9 . 3 0}$ & 44.11 & $\mathbf{5 . 0 1}$ & 18.20 \\
\hline 419 & $39132-5 \mathrm{~A}$ & $\mathbf{- 1 9 . 2 5}$ & 44.35 & $\mathbf{5 . 0 8}$ & 18.28 \\
\hline 420 & $39132-6 \mathrm{~A}$ & $\mathbf{- 1 9 . 2 9}$ & 44.13 & $\mathbf{4 . 7 2}$ & 18.34 \\
\hline 421 & $39132-6 \mathrm{~A} d u p$ & $\mathbf{- 1 9 . 2 8}$ & 44.12 & $\mathbf{5 . 0 5}$ & 18.24 \\
\hline 422 & $39132-7 \mathrm{~A}$ & $\mathbf{- 1 9 . 2 8}$ & 44.01 & $\mathbf{4 . 9 6}$ & 18.24 \\
\hline 423 & $39132-8 \mathrm{~A}$ & $\mathbf{- 1 9 . 0 3}$ & 44.04 & $\mathbf{5 . 5 4}$ & 18.00 \\
\hline 424 & $39132-9 \mathrm{~A}$ & $\mathbf{- 1 8 . 9 4}$ & 44.53 & $\mathbf{5 . 5 2}$ & 18.53 \\
\hline 425 & $39132-10 \mathrm{~A}$ & $\mathbf{- 1 9 . 1 9}$ & 44.05 & $\mathbf{5 . 1 7}$ & 17.94 \\
\hline 426 & $39132-11 \mathrm{~A}$ & $\mathbf{- 1 9 . 0 1}$ & 44.33 & $\mathbf{5 . 3 1}$ & 18.41 \\
\hline 427 & $39132-12 \mathrm{~A}$ & $\mathbf{- 1 8 . 9 3}$ & 44.02 & $\mathbf{5 . 6 6}$ & 18.30 \\
\hline 428 & $39132-13 \mathrm{~A}$ & $\mathbf{- 1 8 . 8 4}$ & 44.32 & $\mathbf{5 . 3 5}$ & 18.45 \\
\hline 429 & $39132-14 \mathrm{~A}$ & $\mathbf{- 1 8 . 8 8}$ & 39.78 & $\mathbf{5 . 2 9}$ & 16.47 \\
\hline 430 & $39132-14 \mathrm{~A}$ dup & $\mathbf{- 1 8 . 8 1}$ & 36.02 & $\mathbf{5 . 3 7}$ & 14.72 \\
\hline 431 & $39132-15 \mathrm{~A}$ & $\mathbf{- 1 9 . 6 8}$ & 41.18 & $\mathbf{5 . 5 0}$ & 15.90 \\
\hline 432 & $39132-16 \mathrm{~A}$ & $\mathbf{- 1 9 . 1 9}$ & 42.12 & $\mathbf{5 . 5 3}$ & 16.95 \\
\hline 433 & $39132-17 \mathrm{~A}$ & $\mathbf{- 1 9 . 0 7}$ & 35.03 & $\mathbf{5 . 2 5}$ & 13.93 \\
\hline 434 & $39132-18 \mathrm{~A}$ & $\mathbf{- 1 9 . 0 5}$ & 29.70 & $\mathbf{5 . 3 3}$ & 11.62 \\
\hline
\end{tabular}




\begin{tabular}{|l|c|c|c|c|c|}
\hline 435 & $39132-19 A$ & $\mathbf{- 1 9 . 0 3}$ & 35.81 & $\mathbf{5 . 5 1}$ & 14.10 \\
\hline 436 & $39132-20 \mathrm{~A}$ & $\mathbf{- 1 8 . 9 1}$ & 43.04 & $\mathbf{5 . 7 5}$ & 17.27 \\
\hline 437 & $39132-21 \mathrm{~A}$ & $\mathbf{- 1 8 . 6 0}$ & 23.27 & $\mathbf{5 . 1 0}$ & 8.76 \\
\hline 438 & $39132-22 \mathrm{~A}$ & $\mathbf{- 1 8 . 5 6}$ & 23.92 & $\mathbf{4 . 9 7}$ & 8.91 \\
\hline 439 & $39132-23 \mathrm{~A}$ & $\mathbf{- 1 8 . 7 5}$ & 39.29 & $\mathbf{5 . 4 7}$ & 12.64 \\
\hline 440 & $39132-1 \mathrm{~A} A$ & $\mathbf{- 1 9 . 2 8}$ & 44.57 & $\mathbf{5 . 3 4}$ & 15.04 \\
\hline 441 & $39132-2 T A$ & $\mathbf{- 1 9 . 3 4}$ & 44.22 & $\mathbf{4 . 8 8}$ & 14.99 \\
\hline 442 & $39132-3 T A$ & $\mathbf{- 1 8 . 8 1}$ & 44.21 & $\mathbf{5 . 7 3}$ & 15.12 \\
\hline 443 & $39132-3 T A$ dup & $\mathbf{- 1 8 . 7 4}$ & 43.90 & $\mathbf{5 . 8 3}$ & 14.99 \\
\hline 444 & $39132-1 \mathrm{~B}$ & $\mathbf{- 1 9 . 5 4}$ & 22.19 & $\mathbf{3 . 1 8}$ & 6.78 \\
\hline
\end{tabular}

\begin{tabular}{|c|c|c|c|c|c|}
\hline Num & Sample & $\delta^{15} N(A I R)$ & $\mathrm{N} \%$ & $\delta^{13} C$ (VPDB) & $\mathrm{C} \%$ \\
\hline 445 & $39145-1 \mathrm{~A}$ & 3.98 & 14.41 & -18.75 & 39.68 \\
\hline 446 & $39145-2 A$ & 3.86 & 16.32 & -18.78 & 44.44 \\
\hline 447 & $39145-3 A$ & 4.17 & 16.38 & -18.72 & 43.87 \\
\hline 448 & $39145-4 A$ & 4.07 & 16.24 & -18.77 & 44.21 \\
\hline 449 & $39145-5 A$ & 3.58 & 9.80 & -18.65 & 28.18 \\
\hline 450 & 39145-5A dup & 2.49 & 6.39 & -18.45 & 19.48 \\
\hline 451 & $39145-6 A$ & 4.27 & 16.27 & -18.87 & 44.61 \\
\hline 452 & $39145-7 A$ & 3.46 & 9.80 & -18.70 & 28.47 \\
\hline 453 & $39145-8 A$ & 3.72 & 10.81 & -18.71 & 31.19 \\
\hline 454 & $39145-9 A$ & 4.44 & 12.00 & -18.39 & 34.09 \\
\hline 455 & $39145-10 \mathrm{~A}$ & 4.62 & 14.38 & -18.77 & 40.00 \\
\hline 456 & $39145-11 \mathrm{~A}$ & 4.46 & 9.80 & -18.35 & 28.68 \\
\hline 457 & $39145-12 A$ & 4.25 & 9.73 & -18.71 & 28.20 \\
\hline 458 & $39145-13 A$ & 4.39 & 14.43 & -18.78 & 40.18 \\
\hline 459 & $39145-14 A$ & 4.66 & 16.04 & -18.66 & 44.55 \\
\hline 460 & $39145-15 A$ & 4.39 & 11.67 & -18.74 & 33.21 \\
\hline 461 & $39145-16 A$ & 4.67 & 15.34 & -18.65 & 42.19 \\
\hline 462 & 39145-16A dup & 4.62 & 14.70 & -18.81 & 40.32 \\
\hline 463 & $39145-17 A$ & 4.33 & 10.28 & -18.70 & 29.75 \\
\hline 464 & $39145-18 \mathrm{~A}$ & 4.84 & 14.44 & -18.85 & 40.54 \\
\hline 465 & $39145-19 A$ & 4.79 & 11.83 & -18.82 & 33.33 \\
\hline 466 & $39145-20 \mathrm{~A}$ & 4.38 & 9.62 & -18.78 & 28.51 \\
\hline 467 & $39145-21 \mathrm{~A}$ & 5.20 & 13.33 & -18.90 & 37.09 \\
\hline 468 & $39145-22 A$ & 4.90 & 9.40 & -18.55 & 26.95 \\
\hline 469 & $39145-23 A$ & 5.27 & 11.85 & -18.76 & 32.95 \\
\hline 470 & $39145-24 A$ dup & 5.42 & 13.72 & -18.76 & 38.18 \\
\hline 471 & $39145-25 A$ & 5.48 & 13.92 & -18.68 & 41.87 \\
\hline 472 & $39145-26 A$ & 5.32 & 11.52 & -18.59 & 32.88 \\
\hline 473 & $39145-27 A$ & 5.85 & 15.47 & -18.89 & 42.72 \\
\hline 474 & $39145-28 A$ & 5.79 & 13.07 & -18.84 & 37.28 \\
\hline 475 & 39145-1TA & 4.11 & 10.86 & -18.58 & 30.61 \\
\hline 476 & $39145-2 T A$ & 4.28 & 10.58 & -18.70 & 29.92 \\
\hline
\end{tabular}




\begin{tabular}{|l|c|c|c|c|c|}
\hline 477 & $39145-3 T A$ & $\mathbf{5 . 7 6}$ & 11.25 & $\mathbf{- 1 8 . 6 8}$ & 31.96 \\
\hline 478 & $39145-4 T A$ & $\mathbf{4 . 7 1}$ & 7.07 & $\mathbf{- 1 8 . 4 0}$ & 21.59 \\
\hline 479 & $39145-4 T A$ dup & $\mathbf{5 . 0 4}$ & 9.32 & $\mathbf{- 1 8 . 5 2}$ & 26.73 \\
\hline 480 & $39145-1 B$ & $\mathbf{3 . 2 2}$ & 6.29 & $\mathbf{- 1 8 . 6 4}$ & 18.99 \\
\hline 481 & $39145-1 B$ RPT & $\mathbf{3 . 7 9}$ & 6.43 & $\mathbf{- 1 8 . 7 8}$ & 19.74 \\
\hline 482 & $39145-5$ A RPT & $\mathbf{3 . 4 7}$ & 7.32 & $\mathbf{- 1 8 . 6 2}$ & 21.66 \\
\hline
\end{tabular}

\begin{tabular}{|c|c|c|c|c|c|}
\hline Num & Sample & $\delta^{15} N(A I R)$ & $\mathbf{N} \%$ & $\delta^{13} \mathrm{C}$ (VPDB) & $\mathrm{C} \%$ \\
\hline 483 & $39148-1 \mathrm{~A}$ & 4.04 & 16.49 & -19.35 & 44.43 \\
\hline 484 & $39148-2 A$ & 3.99 & 16.60 & -19.24 & 43.72 \\
\hline 485 & $39148-3 A$ & 3.91 & 16.36 & -19.24 & 42.94 \\
\hline 486 & $39148-4 A$ & 3.91 & 16.57 & -19.29 & 43.48 \\
\hline 487 & $39148-5 A$ & 4.31 & 16.59 & -19.22 & 43.91 \\
\hline 488 & $39148-6 A$ & 4.40 & 16.32 & -19.22 & 43.09 \\
\hline 489 & $39148-7 A$ & 3.98 & 16.17 & -19.07 & 44.08 \\
\hline 490 & $39148-8 A$ & 4.25 & 16.30 & -19.13 & 44.19 \\
\hline 491 & 39148-8A dup & 4.27 & 15.94 & -19.51 & 44.78 \\
\hline 492 & 39148-9A & 4.37 & 16.18 & -19.20 & 44.22 \\
\hline 493 & $39148-10 A$ & 4.40 & 16.30 & -19.24 & 45.33 \\
\hline 494 & $39148-11 \mathrm{~A}$ & 4.58 & 16.45 & -19.14 & 45.28 \\
\hline 495 & $39148-12 A$ & 4.68 & 15.99 & -19.24 & 44.17 \\
\hline 496 & $39148-13 A$ & 4.39 & 16.08 & -19.22 & 44.36 \\
\hline 497 & $39148-14 \mathrm{~A}$ & 4.46 & 16.26 & -19.16 & 44.84 \\
\hline 498 & $39148-15 A$ & 4.32 & 16.37 & -19.13 & 44.74 \\
\hline 499 & $39148-16 A$ & 4.48 & 16.40 & -19.11 & 44.70 \\
\hline 500 & $39148-17 A$ & 4.62 & 16.56 & -19.02 & 44.79 \\
\hline 501 & $39148-18 A$ & 4.64 & 15.96 & -19.25 & 44.80 \\
\hline 502 & 39148-19A & 4.55 & 16.45 & -19.11 & 44.79 \\
\hline 503 & $39148-20 A$ & 4.53 & 16.48 & -19.04 & 44.88 \\
\hline 504 & 39148-20A dup & 4.52 & 16.57 & -19.01 & 45.02 \\
\hline 505 & $39148-21 \mathrm{~A}$ & 4.60 & 16.23 & -19.06 & 44.38 \\
\hline 506 & $39148-22 A$ & 4.76 & 16.47 & -18.98 & 45.05 \\
\hline 507 & $39148-23 A$ & 4.68 & 16.02 & -19.02 & 44.56 \\
\hline 508 & $39148-24 A$ & 4.73 & 16.10 & -18.80 & 44.54 \\
\hline 509 & $39148-25 A$ & 4.96 & 15.96 & -18.89 & 44.88 \\
\hline 510 & 39148-1TA & 4.67 & 16.50 & -19.12 & 44.84 \\
\hline 511 & 39148-1TA dup & 4.43 & 16.43 & -19.13 & 45.20 \\
\hline 512 & 39148-2TA & 4.93 & 16.57 & -18.96 & 44.90 \\
\hline 513 & $39148-1 B$ & 3.23 & 15.75 & -19.07 & 44.85 \\
\hline
\end{tabular}

\begin{tabular}{|c|c|c|c|c|c|}
\hline Num & Sample & $\boldsymbol{\delta}^{\mathbf{1 5}} \mathbf{N}($ AIR) & $\mathbf{N} \%$ & $\boldsymbol{\delta}^{\mathbf{1 5}} \mathbf{N}($ AIR) & $\mathbf{N} \%$ \\
\hline 514 & 39149-1A & $\mathbf{4 . 6 0}$ & 15.48 & $\mathbf{- 1 9 . 0 5}$ & 43.29 \\
\hline 515 & 39149-2A & $\mathbf{4 . 6 1}$ & 15.75 & $\mathbf{- 1 8 . 9 4}$ & 42.86 \\
\hline 516 & 39149-3A & $\mathbf{4 . 5 8}$ & 16.75 & $\mathbf{- 1 8 . 9 5}$ & 45.37 \\
\hline
\end{tabular}




\begin{tabular}{|c|c|c|c|c|c|}
\hline 517 & $39149-4 A$ & 4.47 & 13.82 & -18.82 & 38.17 \\
\hline 518 & $39149-5 A$ & 2.26 & 5.01 & -18.36 & 17.12 \\
\hline 519 & 39149-5A dup & 3.49 & 6.61 & -18.42 & 19.99 \\
\hline 520 & $39149-6 A$ & 4.91 & 15.11 & -18.98 & 41.94 \\
\hline 521 & $39149-7 A$ & 4.66 & 13.68 & -18.83 & 37.71 \\
\hline 522 & $39149-8 A$ & 4.80 & 16.59 & -18.87 & 44.98 \\
\hline 523 & 39149-9A & 3.95 & 9.94 & -18.66 & 28.54 \\
\hline 524 & 39149-9A dup & 3.90 & 9.35 & -18.62 & 27.18 \\
\hline 525 & 39149-10A & 4.68 & 12.03 & -18.62 & 33.75 \\
\hline 526 & $39149-11 \mathrm{~A}$ & 5.01 & 16.71 & -18.87 & 45.75 \\
\hline 527 & $39149-12 A$ & 4.27 & 9.95 & -18.60 & 29.08 \\
\hline 528 & 39149-13A & 5.04 & 15.10 & -18.64 & 41.41 \\
\hline 529 & $39149-14 \mathrm{~A}$ & 3.63 & 7.61 & -18.35 & 23.05 \\
\hline 530 & 39149-14A dup & 4.69 & 11.53 & -18.60 & 32.83 \\
\hline 531 & 39149-15A & 4.79 & 12.56 & -18.65 & 35.08 \\
\hline 532 & $39149-16 A$ & 5.10 & 16.11 & -19.05 & 45.23 \\
\hline 533 & $39149-17 A$ & 5.19 & 16.62 & -18.64 & 45.08 \\
\hline 534 & 39149-18A & 5.02 & 16.69 & -18.69 & 45.24 \\
\hline 535 & 39149-19A & 5.37 & 16.58 & -18.73 & 45.26 \\
\hline 536 & $39149-20 \mathrm{~A}$ & 4.67 & 12.75 & -18.86 & 35.95 \\
\hline 537 & $39149-21 \mathrm{~A}$ & 5.06 & 15.99 & -18.87 & 43.88 \\
\hline 538 & $39149-22 A$ & 4.58 & 11.47 & -18.85 & 32.97 \\
\hline 539 & $39149-23 A$ & 4.50 & 12.58 & -18.89 & 36.02 \\
\hline 540 & $39149-24 \mathrm{~A}$ & 4.86 & 13.86 & -18.73 & 38.73 \\
\hline 541 & 39149-24A dup & 4.86 & 13.26 & -18.72 & 37.02 \\
\hline 542 & $39149-25 A$ & 4.48 & 12.52 & -18.37 & 35.40 \\
\hline 543 & $39149-26 A$ & 4.25 & 11.92 & -18.32 & 34.10 \\
\hline 544 & $39149-27 A$ & 4.05 & 10.60 & -18.50 & 32.13 \\
\hline 545 & 39149-1TA & 4.84 & 13.36 & -18.87 & 37.33 \\
\hline 546 & $39149-2 T A$ & 4.35 & 9.89 & -18.94 & 29.45 \\
\hline 547 & 39149-3TA & 4.34 & 10.74 & -18.22 & 30.90 \\
\hline 548 & 39149-4TA & 4.27 & 12.65 & -18.17 & 36.35 \\
\hline 549 & 39149-1B & 4.31 & 13.96 & -19.52 & 43.71 \\
\hline
\end{tabular}

\begin{tabular}{|c|c|c|c|c|c|}
\hline Num & Sample & $\boldsymbol{\delta}^{\mathbf{1 3}} \mathbf{C}$ (VPDB) & $\mathbf{C \%}$ & $\boldsymbol{\delta}^{\mathbf{1 5}} \mathbf{N}(\mathbf{A I R})$ & $\mathbf{N} \%$ \\
\hline 550 & $39151-1 \mathrm{~A}$ & $\mathbf{- 1 9 . 0 5}$ & 45.32 & $\mathbf{4 . 4 0}$ & 16.76 \\
\hline 551 & $39151-2 \mathrm{~A}$ & $\mathbf{- 1 9 . 1 4}$ & 45.55 & $\mathbf{4 . 5 7}$ & 16.96 \\
\hline 552 & $39151-3 \mathrm{~A}$ & $\mathbf{- 1 9 . 1 0}$ & 45.59 & $\mathbf{4 . 6 5}$ & 16.93 \\
\hline 553 & $39151-4 \mathrm{~A}$ & $\mathbf{- 1 9 . 0 7}$ & 45.08 & $\mathbf{4 . 7 0}$ & 16.78 \\
\hline 554 & $39151-5 \mathrm{~A}$ & $\mathbf{- 1 9 . 0 6}$ & 44.91 & $\mathbf{4 . 7 7}$ & 16.78 \\
\hline 555 & $39151-6 \mathrm{~A}$ & $\mathbf{- 1 9 . 0 2}$ & 45.94 & $\mathbf{4 . 8 9}$ & 17.18 \\
\hline 556 & $39151-7 \mathrm{~A}$ & $\mathbf{- 1 9 . 0 6}$ & 45.26 & $\mathbf{5 . 2 1}$ & 16.92 \\
\hline 557 & $39151-7 \mathrm{~A}$ dup & $\mathbf{- 1 9 . 0 4}$ & 45.03 & $\mathbf{4 . 7 9}$ & 16.89 \\
\hline 558 & $39151-8 \mathrm{~A}$ & $\mathbf{- 1 9 . 0 8}$ & 45.15 & $\mathbf{5 . 1 3}$ & 16.81 \\
\hline
\end{tabular}




\begin{tabular}{|c|c|c|c|c|c|}
\hline 559 & $39151-9 A$ & -19.01 & 45.36 & 5.32 & 16.98 \\
\hline 560 & 39151-10A & -19.04 & 45.07 & 5.11 & 16.67 \\
\hline 561 & $39151-11 \mathrm{~A}$ & -19.10 & 45.59 & 5.09 & 16.97 \\
\hline 562 & 39151-11A dup & -19.17 & 45.26 & 5.07 & 16.92 \\
\hline 563 & 39151-12A & -19.00 & 45.51 & 5.58 & 16.86 \\
\hline 564 & $39151-13 A$ & -19.04 & 45.26 & 5.35 & 16.91 \\
\hline 565 & $39151-14 A$ & -19.15 & 44.41 & 5.13 & 16.59 \\
\hline 566 & 39151-15A & -19.08 & 44.97 & 5.40 & 16.86 \\
\hline 567 & 39151-16A & -19.01 & 45.06 & 5.51 & 16.95 \\
\hline 568 & 39151-17A & -19.05 & 44.77 & 5.67 & 16.93 \\
\hline 569 & 39151-18A & -18.98 & 44.59 & 5.63 & 16.09 \\
\hline 570 & 39151-19A & -19.00 & 44.11 & 5.64 & 15.84 \\
\hline 571 & $39151-20 A$ & -18.96 & 44.63 & 5.72 & 16.06 \\
\hline 572 & 39151-20A dup & -19.02 & 44.59 & 5.79 & 16.01 \\
\hline 573 & $39151-21 \mathrm{~A}$ & -19.09 & 44.70 & 5.60 & 16.02 \\
\hline 574 & $39151-22 A$ & -19.10 & 44.43 & 5.72 & 16.00 \\
\hline 575 & $39151-23 A$ & -19.03 & 44.71 & 5.80 & 16.09 \\
\hline 576 & $39151-24 \mathrm{~A}$ & -18.96 & 44.94 & 6.02 & 16.06 \\
\hline 577 & $39151-25 A$ & -18.93 & 44.23 & 6.06 & 15.75 \\
\hline 578 & $39151-26 A$ & -18.76 & 46.00 & 6.18 & 16.30 \\
\hline 579 & 39151-1TA & -19.14 & 35.23 & 4.52 & 12.44 \\
\hline 580 & 39151-2TA & -18.96 & 37.02 & 4.63 & 13.35 \\
\hline 581 & 39151-3TA & -19.11 & 41.47 & 4.47 & 14.98 \\
\hline 582 & 39151-4TA & -18.84 & 44.73 & 6.15 & 15.96 \\
\hline 583 & 39151-4TA dup & -18.87 & 44.77 & 6.06 & 15.87 \\
\hline 584 & 39151-1B & -18.79 & 45.14 & 4.99 & 15.60 \\
\hline
\end{tabular}

